\title{
ESTRUTURA E DINÂMICA DO ESTRATO ARBÓREO E DA REGENERAÇÃO NATURAL EM ÁREAS RESTAURADAS
}

\section{FLAVIANA MALUF DE SOUZA}

Engenheira Florestal

Orientador: Prof. Dr. JOÃO LUÍS FERREIRA BATISTA

Dissertação apresentada à Escola Superior de Agricultura "Luiz de Queiroz", Universidade de São Paulo, para obtenção do título de Mestre em Ciências, Área de Concentração: Ciências Florestais.

PIRACICABA

Estado de São Paulo - Brasil

Agosto - 2000 
Dados Internacionais de Catalogação na Publicação (CIP)

DIVISĂO DE BIBLIOTECA E DOCUMENTAÇÃO - Campus "Luiz de Oueiroz"/USP

Souza, Flaviana Maluf de

Estrutura e dinâmica do estrato arbóreo e da regeneraçāo natural em áreas

restauradas / Flaviana Maluf de Souza.. - Piracicaba, 2000.

69 p. : il.

Dissertação (mestrado) - Escola Superior de Agricultura Luiz de Queiroz, 2000.

Bibliografia.

1. Composição floristica 2. Diversidade 3. Recuperação 4. Regeneraçāo natural 5. Sucessão vegetal I. Título 


\section{AGRADECIMENTOS}

Ao professor João Batista, pela orientação e pela confiança;

À CESP, por permitir a realização do estudo em suas áreas, e ao Engenheiro Washington Luiz de A. Geres pelo apoio;

A professora Ruth Kunzli, da UNESP de Presidente Prudente, e ao diretor do CESPRI (Centro de Ensino Superior de Primavera), José Wanderley, pelo alojamento em Primavera;

À FAPESP, pela bolsa de estudos e pela reserva técnica, e por possibilitar e facilitar imensamente o desenvolvimento de pesquisas no Estado de São Paulo;

A Sandra Pavan, pelo pontapé inicial com a ajuda financeira;

Aos especialistas consultados, pela presteza na identificação das espécies: Flávia Garcia, Pedro Carauta, Jorge Tamashiro, Vinícius Castro Souza e em especial ao Geraldinho (Geraldo Franco), por sempre arrumar uma brecha nas suas idas e vindas para identificar os materiais;

Aos professores do Departamento de Ciências Biológicas da ESALQ Ricardo Ribeiro Rodrigues e Sergius Gandolfi;; pelas discušsões e pelas vallosią contribuições a este trabalho;

A Giselda Durigan, pela leitura do boneco da qualificação e pelas correções feitas em tão pouco tempo;

Aos funcionários do Departámentón de Ciênicias Flörestais e IPEF: Dirceu, Zé Martins, Ivo, Rogério, Erivelto, Margareth e Silvana, um agradecimento especialíssimo pelos inúmeros galhos quebrados;

Ao Pi (Hélio Passoș), por ter segurado a $_{i}$ barra, financeira ${ }_{i}$ e emocionalmente, no tão difícil começo...;

Aos meninos dờ LMQ, pela agradável convivência, e por me fazerem entender um pouco melhor o universo masculino!;

Ao Jefferson, pela super ajuda nos trabalhos de campo pela extrema boa vontade na hora de resolver os pepinós do laboratório; is a

Aos estagiários Limonada (Flávio L. Cremonesi) e Casado (Márcio S. Cardoso) pelo trampo no campo, pelas risadas, pelo bom-humor e pela serenata!;

Ao Gnomo (Maurício Gorenstein), pela disposição e pela ajuda na identificação das espécies no campo;

Ao Araújo ("Magaiver"), por ter sido, além de motorista, escalador de árvores, medidor de plantas e criador de engenhocas; 
Ao "Guto" (Beija-flor), pelas incansáveis leituras da dissertação, desde os tempos de relatório FAPESP, e por ter me despertado tantas coisas importantes (apesar dos contratempos!...);

Ao Era, pelos anos de vida "conjugal" inesquecíveis, pelas longas conversas madrugada adentro e por conseguir me surpreender a cada minuto!;

A Alê, super assessora e companheira nos estudos da Língua Portuguesa, pelas leituras, correções, sugestões, e principalmente pelo agradável convívio na casa nova e pelas ferveções, que ainda serão muitas!;

Ao Roko (Fabiano Rodrigues), amigo querido, por estar presente, sempre;

A Lud, "Terceira Elementa", pela sua alegria, pelos seus "ensinamentos" e pelas boas risadas que demos (e ainda daremos) com sua vasta experiência em assuntos domésticos;

A minha mãe querida, pelo amor e pelo socorro financeiro nas horas de aperto;

Aos amigos de Pira, em especial Carlinha Gheler, Márcio Sztutman, Val, Laurão, Adri, Baiano, Nelore (Bifão) e Paula, Marcelino, Geraldo, Bolaxa, Viviane (Inhóq), e o casal Fê e Má, pelas risadas, pelo carinho e pelas alegrias e angústias compartilhadas nestes anos de pós. 


\section{SUMÁRIO}

Página

RESUMO . V

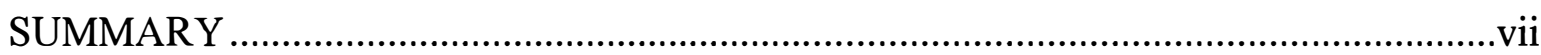

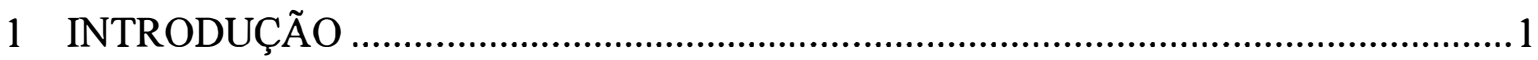

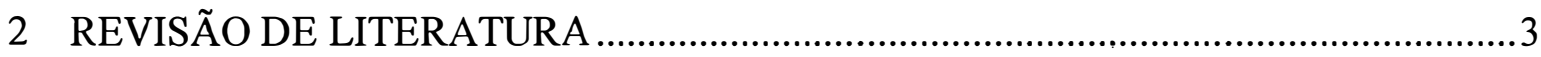

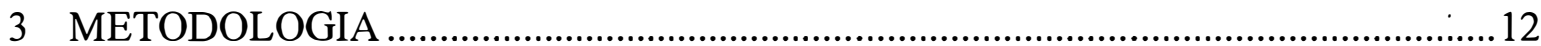

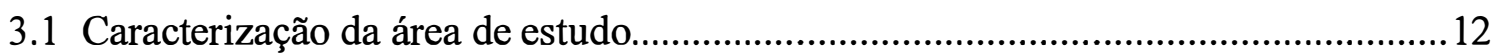

3.1.1 Localização geográfica e características edafo-climáticas........................... 12

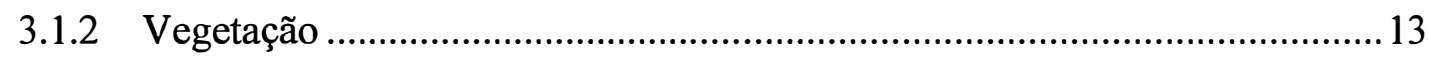

3.1.3 Caracterização das áreas restauradas .......................................................13

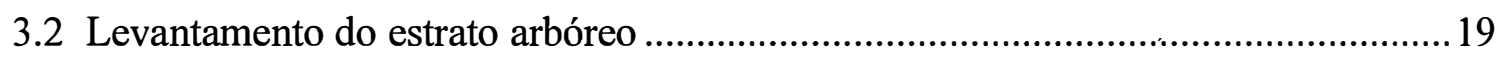

3.2.1 Composição, estrutura e dinâmica................................................................. 19

3.2.2 Densidade de copa e plantas herbáceas .........................................................21

3.3 Levantamento da regeneração natural .....................................................................22

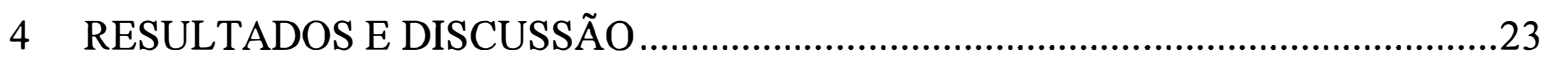

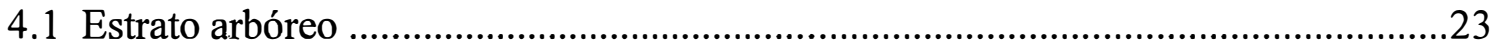

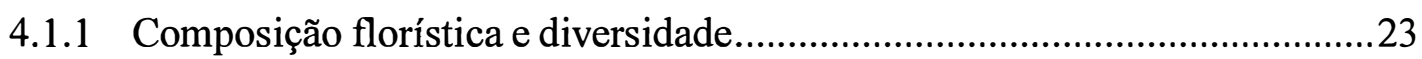

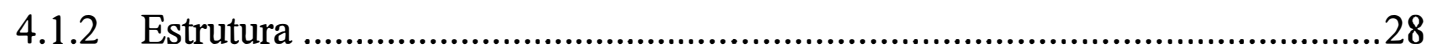

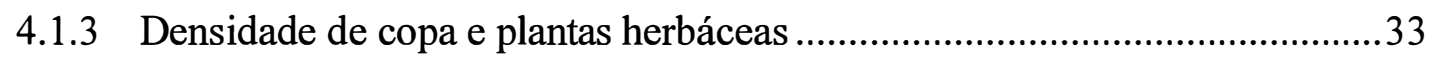

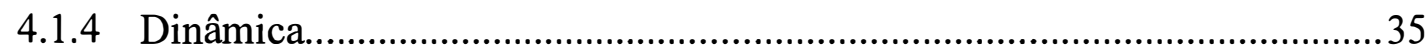

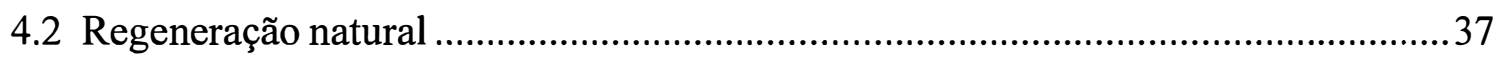

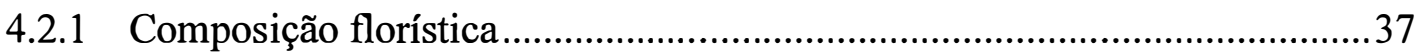

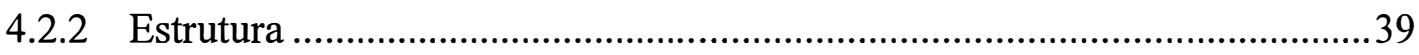

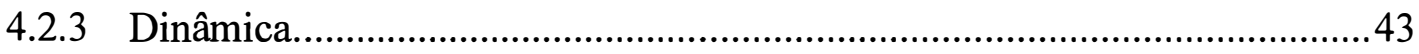

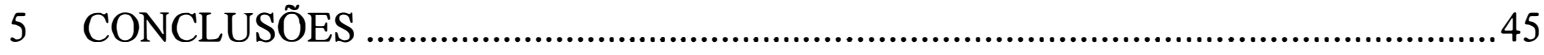

6 IMPLICAÇÕES PARA A RESTAURAÇÃO.............................................................4

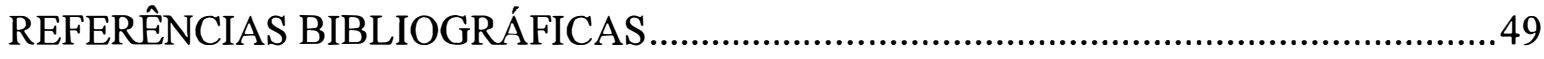

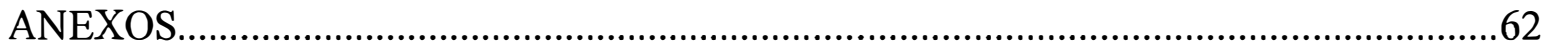




\title{
ESTRUTURA E DINÂMICA DO ESTRATO ARBÓREO E DA REGENERAÇÃO NATURAL EM ÁREAS RESTAURADAS
}

\author{
Autora: FLAVIANA MALUF DE SOUZA \\ Orientador: Prof. Dr. JOÃO LUÍS FERREIRA BATISTA
}

\section{RESUMO}

O objetivo deste estudo foi avaliar a estrutura e a dinâmica do estrato arbóreo e da regeneração natural de florestas formadas a partir de plantios mistos com espécies nativas. As áreas estudadas situam-se nas margens dos reservatórios das usinas hidroelétricas da antiga Companhia Energética do Estado de São Paulo (CESP) e foram plantadas nos anos de 1988, 1989 e 1993, com diferentes modelos de plantio. A principal diferença entre os modelos de plantio está na proporção de árvores pioneiras. Nas áreas plantadas em 1989 e 1993 esta proporção é de cerca de 50 \%, enquanto que na área plantada em 1988 é de aproximadamente $20 \%$. Para o estudo do estrato arbóreo (indivíduos com circunferência à altura do peito - CAP $\geq 15 \mathrm{~cm}$ ) foram instaladas parcelas permanentes de $30 \times 30\left(900 \mathrm{~m}^{2}\right)$ nas quais foram medidos o CAP, a altura total e o índice de posição da copa no dossel. Para o estudo da regeneração natural, foram sorteadas seis sub-parcelas de $1 \mathrm{~m}$ de raio $\left(3,14 \mathrm{~m}^{2}\right)$ dentro de cada parcela utilizada no levantamento do estrato arbóreo. Nestas sub-parcelas, fez-se a contagem, a identificação e a medição da altura dos indivíduos lenhosos com altura $\geq 50 \mathrm{~cm}$ e CAP $<15 \mathrm{~cm}$. Foi realizado também um levantamento da densidade de copa e de plantas herbáceas com um densitômetro vertical, através do qual registrou-se a presença/ausência de cobertura em pontos distribuídos dentro de cada parcela de $900 \mathrm{~m}^{2}$. Para o estudo da dinâmica, 
todos os parâmetros foram reavaliados após um ano. Os índices de diversidade de Shannon $\left(\mathrm{H}^{\prime}\right)$ e equabilidade $(J)$ encontrados para as áreas plantadas em 1988, 1989 e 1993 foram 3,03/0,84, 2,45/0,71 e 2,18/0,66, respectivamente. A área basal e a altura média do estrato arbóreo na área plantada em 1989 foram superiores aos valores encontrados na área plantada em 1988. Os valores de mortalidade e recrutamento estão seguindo os rumos da sucessão secundária, com maior mortalidade de espécies pioneiras e recrutamento de secundárias iniciais seguido de secundárias tardias e climácicas em todas as idades de plantio. A persistência de plantas herbáceas (capim colonião Panicum maximum L.) nas áreas estudadas apresentou uma relação com a abertura no dossel na estação seca, proporcionada pela queda das folhas de algumas espécies. A densidade de plantas provenientes da regeneração natural registrada no primeiro levantamento foi cerca de 6.500 indivíduos/ha na área plantada em 1988 e 3.450 indivíduos/ha para a área plantada em 1989. Na área plantada em 1993, não se observou nenhum indivíduo em regeneração no primeiro levantamento. Das espécies arbóreas amostradas no levantamento da regeneração natural, apenas uma (Bastardiopsis densiflora (Hook et Arn.) Hassl.) parece ter vindo de outros remanescentes florestais ou do banco de sementes do solo. A distribuição dos indivíduos de acordo com os grupos ecológicos no plantio exerceu influência direta no desenvolvimento da estrutura da floresta, determinando também os padrões da dinâmica sucessional, como as taxas de mortalidade e recrutamento. De maneira geral, a área plantada em 1988 foi a que mais se assemelhou à floresta natural. 


\title{
OVERSTOREY AND UNDERSTOREY STRUCTURE AND DYNAMICS IN RESTORATION FORESTS
}

\author{
Author: FLAVIANA MALUF DE SOUZA \\ Adviser: Prof. Dr. JOÃO LUÍS FERREIRA BATISTA
}

\section{SUMMARY}

Overstorey and understorey structure and dynamics were studied in 10,9 and 5year-old mixed native species reforestation area at Companhia Energética do Estado de São Paulo (CESP) reservoir margins. The study areas were planted using two different plantation strategies. In 9 and 5-year-old forests, the proportion of pioneer trees was about $50 \%$, while in 10-year-old forest it was $20 \%$. For the overstorey study (stem circunference at breast height $\geq 15 \mathrm{~cm}$ ), circunference at breast height, heigth and a crown position index were measured in $900 \mathrm{~m}^{2}$ permanent plots. For the understorey study (woody regeneration $\geq 50 \mathrm{~cm}$ in height and stem circunference at breast height $<$ $15 \mathrm{~cm}$ ) six 1-m radius subplots were established in each overstorey plot, and all woody plant species were counted and identified. Canopy and herbaceous densities were determined using a vertical densitometer, in which cover presence/absence was assessed in points along transects. For the dynamics study, all the parameters were evaluated one year later. Shannon diversity $\left(H^{\prime}\right)$ and eveness $(J)$ indexes found for 10, 9 and 5-year-old forests were $3.03 / 0.84,2.45 / 0.71$ and $2.18 / 0.66$, respectively. The mean basal area and height in 9-year-old overstorey were greater than 10-year-old forest. Greater mortality values for pioneer tree species and greater recruitment for early, late secondary and climax species, respectively, were observed in all sites, according to secondary 
succession theory. Herbaceous vegetation (Panicum maximum L.) persistence was related to the canopy opening in the dry season, varying with the degree of leaf shedding of some species. Woody regeneration density values were 6,500 individuals/ha in 10year-old forest and 3,450 individuals/ha in 9-year-old forest. At the 5-year-old forest, no regenerating individuals were found in the first survey. From all tree species found in the regeneration survey, just one (Bastardiopsis densiflora (Hook et Arn.) Hassl.) seemed to have arrived from forest fragments or emerged from the soil seed bank. The proportion of trees of different ecological guilds in the restoration forests influenced the forest structure and dynamics. The 10-year-old site was the most similar to the natural forest. 


\section{INTRODUÇÃO}

O declínio da biodiversidade que preocupa a comunidade científica em todo o mundo é mais acentuado nos países tropicais (Wilson 1997, Young 2000). Se por um lado estes habitats contêm mais da metade das espécies da biota mundial, por outro apresentam as mais altas taxas de degradação, resultando na extinção de muitas espécies e, conseqüentemente, na perda irreversível da diversidade biológica (Wilson 1997).

A importância da restauração das áreas degradadas surge a partir deste quadro, já que ela pode ser uma forma alternativa de manutenção da biodiversidade (Bawa \& Seidler 1998). Além de ser uma ferramenta complementar às práticas conservacionistas através da criação de habitats para espécies animais e vegetais ameaçadas (Jordan III et al. 1988), a restauração pode trazer grandes contribuições ao conhecimento da ecologia (Jordan III et al. 1987, Palmer et al. 1997). O processo de restaurar permite o teste de hipóteses e a observação do comportamento das espécies. e do funcionamento dos ecossistemas, o que pode ser muito importante para auxiliar as práticas de manejo e conservação das florestas.

Apesar de seu potencial, a prática da restauração é ainda muito recente (Jordan III et al. 1988). Poucas são as áreas restauradas em grande escala e menores ainda são as iniciativas de avaliação e monitoramento das mesmas (Jordan III et al. 1988).

A complexidade da estrutura e do funcionamento dos ecossistemas tropicais, além da escassez de informações sobre a ecologia das espécies são alguns dos fatores que dificultam a restauração. Há ainda muitos problemas metodológicos, carência de dados extensos e poucos exemplos que descrevam detalhadamente os processos de restauração (Kelly \& Harwell 1990, Jansen 1997, Michener 1997). 
Desta forma, a avaliação e o monitoramento das áreas já restauradas são fundamentais para o aprimoramento das metodologias empregadas na restauração (Jackson et al. 1995, Kondolf 1995, Hobbs \& Norton 1996, van Aarde et al. 1996; Clewell \& Rieger 1997), embora os parâmetros mais adequados para tal avaliação ainda não sejam conhecidos (Higgs 1997).

No Brasil, são poucos os trabalhos que tratam da avaliação do sucesso dos reflorestamentos e da eficiência das técnicas utilizadas até então. Segundo Kageyama \& Gandara (no prelo), são ainda muito duvidosas as possibilidades de polinização, dispersão, regeneração e predação natural, fatores essenciais na manutenção dos processos ecológicos das florestas já implantadas. Portanto, ainda não se pode afirmar se esses reflorestamentos conseguirão efetivamente constituir um novo ecossistema capaz de se regenerar e abrigar a fauna do mesmo modo que as florestas naturais.

O objetivo geral deste trabalho é avaliar a estrutura e a dinâmica de florestas com diferentes idades, formadas a partir de plantios mistos com espécies nativas em áreas degradadas, utilizando dois modelos de plantio diferentes. Dentro desta proposta, os objetivos específicos são:

i) Comparar aspectos da composição florística e da diversidade das áreas plantadas com áreas naturais;

ii) Verificar a influência das diferentes proporções de grupos ecológicos (modelos de plantio) em algumas características estruturais das florestas plantadas;

iii) Acompanhar a dinâmica sucessional através do crescimento, mortalidade e recrutamento de novos indivíduos;

iv) Analisar a composição e a estrutura da regeneração natural das florestas plantadas em relação ao estrato arbóreo e a outras florestas naturais. 


\section{REVISÃO DE LITERATURA}

Os impactos da destruição dos ambientes naturais causados pelo ser humano, especialmente nos países tropicais, vêm chamando a atenção da comunidade científica em geral, cujo grande desafio é a manutenção dos atuais níveis de biodiversidade (Wilson 1997, Young 2000).

Através da supressão da vegetação e dos meios de regeneração, como banco de plântulas, chuva de sementes e rebrota, ocorre a degradação das áreas naturais. Estas áreas degradadas apresentam baixa resiliência, ou seja, o seu retorno ao estado anterior pode não ocorrer ou ser extremamente lento (Carpanezzi et al. 1990).

Neste contexto, processos como a restauração dessas áreas são fundamentais (Box 1996). Embora sua prática possa ser desencorajada pelo lento desenvolvimento das florestas e pela complexidade de algumas formações florestais, tem despertado grande interesse como uma ferramenta complementar à biologia da conservação na preservação de espécies e comunidades ao redor do mundo (Jordan III et al. 1988, Young 2000) e na manutenção da diversidade das comunidades florestais tropicais (Bawa \& Seidler 1998).

Embora a restauração seja uma atividade obviamente muito mais custosa do que o simples abandono das áreas degradadas à sucessão natural, sua prática traz também várias vantagens, tendo em vista que os reflorestamentos, principalmente quando feitos com espécies nativas (Haggar et al. 1997), podem servir como catalizadores da sucessão nas áreas restauradas.

Esta aceleração da sucessão ocorre principalmente porque a restauração da cobertura vegetal facilita a recolonização da flora através de melhorias na fertilidade, temperatura e umidade do solo, no microclima do sub-bosque, na supressão de 
gramíneas e na formação de habitat para a fauna dispersora de sementes (Parrota 1995, Parrota et al. 1997b, Tucker \& Murphy 1997, Wunderle Jr. 1997).

Muito se tem discutido na literatura sobre a terminologia das atividades ligadas à restauração (Jordan III et al. 1988, Jackson et al. 1995, Hobbs \& Norton 1996, van Aarde 1996, Higgs 1997). No entanto, alguns autores acreditam que a definição dos termos é pouco importante frente aos desafios da prática (Hobbs \& Norton 1996). É claro que uma terminologia bem definida seria útil, mas parece que a comunidade científica está longe de um consenso (Hobbs \& Norton 1996, Higgs 1997).

Jackson et al. (1995) definiram a restauração ecológica como “...o processo de reparar danos causados pelos humanos à diversidade e dinâmica de ecossistemas naturais." Hobbs \& Norton (1996) incluem nesta definição o conceito de produtividade, acreditando que a conservação e a produção devem ser consideradas simultaneamente em projetos de grande escala.

Jackson et al. (1995) apresentam também definições de outras atividades relacionadas à restauração, algumas delas utilizadas amplamente, sem grandes distinções:

"Considerada com um objetivo menor do que a restauração completa, a recuperação (reclamation) foi definida como resultante num ecossistema estável e auto-sustentável que pode ou não incluir algumas espécies exóticas e que inclui uma estrutura e função similares mas não idênticas às da formação original (National Academy of Science 1974). A reabilitação (rehabilitation) foi definida no mesmo estudo como o ato de tornar a terra útil novamente após um distúrbio. A criação (creation) envolve atividades que produzem um ecossistema persistente, mas desenvolvidas numa área que previamente não comportava o ecossistema criado. Mitigação (mitigation) se refere às atividades que reduzam o grau de degradação de um ecossistema e pode incluir quaisquer das atividades acima descritas. Diferente das outras atividades, entretanto, a mitigação pode resultar na destruição de um ecossistema existente em troca da criação de outro."

O mais importante dentro destas definições é perceber que as atividades de reabilitação, recuperação e restauração formam um contínuo no qual os resultados variam em relação ao grau de similaridade à condição existente antes do distúrbio, indo 
do menos para o mais similar, respectivamente (Jackson et al. 1995). Este gradiente parece ser um pouco mais consensual entre os pesquisadores ligados à restauração.

Tendo em vista que restauração é o termo atualmente mais utilizado (ex. Jordan III et al. 1987, Robinson \& Handel 1993, Kondolf 1995, Aronson \& Le Floc'h 1996, Bell et al. 1997, Fang \& Peng 1997, Higgs 1997, Jansen 1997, Walters 1997, Majer \& Nichols 1998, Holl \& Kappelle 1999, Lesica \& Allendorf 1999, Parrota \& Knowles 1999 etc.), este será também o termo utilizado nö presente trabalho para referir-se a qualquer iniciativa de restabelecimento da vegetação em áreas degradadas.

Mais do que um simples conceito, é preciso compreender a relevância do processo de restauração. Além de servir como forma alternativa às práticas conservacionistas através da criação de habitats para comunidades vegetais e animais ameaçadas, a restauração é,uma importante peça na pesquisa da ecologia (Jordan III et al. 1987, Palmer et al. 1997).

Embora raramente utilizada com este propósito, a restauração permite o teste de idéías e a avaliação de hipóteses sobre as comunidades (Jordan III et al. 1987), e de questões como a teoria da sucessão, aspectos genéticos (Ashby 1987) e fatores determinantes dos padrões da vegetação e da manutenção da biodiversidade das comunidades vegetais (Ashby 1987, Gross 1987). A prática da restauração torna-se, portanto, uma excelente oportunidade para a avaliação do nível de conhecimento sobre o funcionamento dos ecossistemas (Aber 1987, Bradshaw 1987, Harper 1987).

Muitas das questões a respeito da restauração ainda existem por tratar-se de um assunto relativamente recente (Jordan III et al. 1988, Bell et al. 1997, Palmer et al. 1997). Há ainda muitos problemas metodológicos, carência de dados extensos e poucos exemplos que descrevam detalhadamente os processos de restauração (Kelly \& Harwell 1990, Jansen 1997, Michener 1997).

Segundo Jordan III et al. (1988), muito poucas restaurações já foram realizadas de fato e menos ainda têm sido monitoradas durante longos períodos. Nas regiões tropicais, a maior parte das pesquisas relacionadas à restauração ainda está em estágio inicial de desenvolvimento (Wunderle Jr. 1997) pois têm sido conduzidas nos últimos cinco a 10 anos (Holl \& Kappelle 1999). 
No Brasil, são poucos os trabalhos que tratam da avaliação do sucesso dos reflorestamentos e da eficiência das técnicas utilizadas até então. Segundo Kageyama \& Gandara (no prelo), são ainda muito duvidosas as possibilidades de polinização, dispersão, regeneração e predação natural, fatores essenciais na manutenção dos processos ecológicos das florestas já implantadas. Na verdade, ainda não se pode afirmar se esses reflorestamentos conseguirão efetivamente constituir um novo ecossistema capaz de se regenerar e abrigar a fauna do mesmo modo que as florestas naturais.

Além disso, os parâmetros técnicos que devem ser utilizados como indicadores do sucesso dos reflorestamentos ainda não são totalmente conhecidos (Higgs 1997) e a definição de critérios que permitam verificar se os objetivos da restauração foram alcançados é essencial para o aprimoramento das técnicas existentes (Jackson et al. 1995, Kondolf 1995, Hobbs \& Norton 1996, van Aarde et al. 1996, Clewell \& Rieger 1997).

Jackson et al. (1995) sugerem alguns critérios para avaliar o sucesso da restauração, como a cobertura, a presença e a distribuição de espécies de plantas, a habilidade de resposta da vegetação a distúrbios e flutuações climáticas, o uso da área por determinadas espécies animais, a condição do solo e sua colonização por invertebrados, fungos e bactérias, a ciclagem de nutrientes e o regime hidrológico. As taxas de decomposição também podem ser úteis como indicadores do estágio da restauração (Ehrenfeld \& Toth 1997). Aronson \& Le Floc'h (1996), por sua vez, propõem uma série de atributos da paisagem ("Vital Landscape Attributes") para a avaliação da trajetória dos ecossistemas.

Tendo em vista que as plantas constituem a base dos projetos de restauração (Gilpin 1987, Young 2000), a grande maioria dos parâmetros que vêm sendo utilizados nas avaliações das áreas restauradas são relativos à vegetação. As medidas mais comumente utilizadas referem-se à estrutura e composição tanto do estrato arbóreo (área basal, altura, densidade, número de espécies e densidade de copa) quanto do sub-bosque (densidade e número de espécies estabelecidas através de regeneração natural), além da densidade e número de espécies das plantas representantes de outras formas de vida, tais como arbustos, herbáceas, gramíneas e lianas (ex. McLean \& Wein 1977, Guariguata et 
al. 1995, Larson 1996, Shear et al. 1996, van Aarde et al. 1996, Allen 1997, Fang \& Peng 1997, Haggar et al. 1997, Parrota et al. 1997a, Jansen 1997, Clewell 1999, Parrota \& Knowles 1999).

No entanto, na perspectiva de encontrar indicadores do sucesso das restaurações, outros parâmetros também vêm sendo estudados. As formigas têm sido muito usadas na avaliação de projetos de restauração (Andersen \& Sparling 1997, Andersen \& Morrison 1998, Majer \& Nichols 1998) e podem ser uma valiosa indicação de sustentabilidade, em virtude de sua associação aos processos ecológicos importantes na dinâmica dos ecossistemas, como por exemplo a dispersão de sementes (Andersen \& Morrison 1998).

Rosenberg et al. (1986) ressaltam que os insetos contribuem com uma série de processos ecológicos nas florestas, desempenhando papel de predadores, parasitas, herbívoros, saprófitas, polinizadores, entre outros, e podem fornecer informações sobre eventos ocorridos há muito tempo, contribuindo para a predição das mudanças a partir de perturbações similares. Os vertebrados de serapilheira (Jansen 1997, Tucker \& Murphy 1997) e a atividade microbiana do solo também podem ser bons indicadores do sucesso da restauração (Bentham et al. 1992).

Pequenos mamíferos (van Aarde et al. 1996, Tucker \& Murphy 1997), aves, morcegos (van Aarde et al. 1996, Parrota et al. 1997a), répteis (Tucker \& Murphy 1997), besouros e até centopéias (van Aarde et al. 1996) já foram utilizados ou recomendados em estudos de áreas restauradas.

Em alguns casos, espécies vegetais ou animais são utilizadas como indicadoras da qualidade do habitat. Landres et al. (1988) comentam que na maioria das vezes esta utilização é inadequada, como no caso das extrapolações do uso de indicadores de uma área para outra. Apesar das dificuldades e do rigor com que esta questão deve ser tratada (Landres et al. 1988), Kelly \& Harwell (1990) ressaltam a necessidade de indicadores, principalmente para a deteç̧ão de alterações em grande escala espacial e temporal.

Outras ferramentas para diagnosticar e subsidiar os procedimentos de restauração são o sensoriamento remoto (Phinn et al. 1996, Clewell \& Rieger 1997) e a utilização de cronoseqüências, que nada mais são que estudos de áreas com diferentes 
idades, complementares aos estudos de longo prazo (Stohlgren 1995). O monitoramento é indicado como a melhor maneira de confirmar as tendências observadas (Tucker \& Murphy 1997) e promover uma análise mais apurada do sucesso da restauração (Kondolf 1995, Salomão et al. 1997, Rodrigues \& Gandolfi 1998).

A comparação da área restaurada a um local de referência (Kondolf 1995, Shear et al. 1996, van Aarde et al. 1996, Clewell \& Rieger 1997, White \& Walker 1997) que tenha características semelhantes às da condição originalmente existente, ou da condição que se deseja alcançar com a restauração, pode auxiliar a avaliação do sucesso dos projetos de restauração.

Porém, a escolha de um local de referência pode ser um fator complicante no processo de avaliação da área restaurada, devendo ser feita com cautela (Kondolf 1995). Isto porque, ao selecionar-se uma área de referência para a restauração, é preciso que os locais e as épocas sejam os mais semelhantes possíveis às condições que desejamos restaurar (White \& Walker 1997).

Alguns dos problemas mais comuns e limitantes na escolha de um local de referência são o pequeno tamanho dos remanescentes, a distância espacial e ambiental da área a ser restaurada, a falta de documentação do histórico ambiental do local (White \& Walker 1997) e a ausência de áreas não ou pouco perturbadas que possam servir para comparação.

White \& Walker (1997) comentam que um local de referência ideal deveria localizar-se próximo à área restaurada, apresentar histórico de perturbações documentado, além de intervenção antrópica e efeitos de fragmentação conhecidos e mínimos. No entanto, estas condições são praticamente impossíveis de serem obtidas para um único local, o que torna muito delicada a escolha de uma área de referência. Além disso, as florestas são dinâmicas e únicas, sendo que nunca haverá um local de referência perfeito para uma área a ser restaurada (White \& Walker 1997).

Um grande equívoco dos projetos de restauração é pressupor que com a restauração da parte vegetal, invariavelmente, a vida animal reaparece de maneira espontânea. Isto só será verdadeiro se houver condições adequadas para o restabelecimento da vida silvestre, o que inclui adequada fonte colonizadora (área 
naturais de onde possam surgir os animais) e recursos alimentares suficientes (Jordan III et al. 1988). Em contrapartida, a ausência de vida silvestre na área restaurada pode comprometer a sustentabilidade da restauração, uma vez que as plantas e os animais são dependentes uns dos outros e sua associação tem influência direta em vários processos ecológicos importantes na perpetuação do ecossistema, como dispersão, polinização, predação etc. (Montalvo et al. 1997).

A fauna - principalmente aves e morcegos nas regiões tropicais (Parrota 1995, Parrota et al. 1997b) - é reconhecidamente importante na dispersão de propágulos (Ḿc Donnell \& Stiles 1983, Guevara et al. 1986, Parrota 1993, Robinson \& Handel 1993, Box 1996, Tucker \& Murphy 1997), processo essencial na sucessão secundária (Mc Donnell \& Stiles 1983, McClanahan 1986, McClanahan \& Wolfe 1993, Robinson \& Handel 1993, Bakker et al. 1996) e na restauração da biodiversidade (Wunderle Jr. 1997).

A ausência da dispersão, aliada a altas taxas de predação limitam a disponibilidade de sementes (Holl \& Lullow 1997) e, conseqüentemente, a eficiência e a velocidade da sucessão secundária.

Alguns fatores podem afetar diretamente a dispersão de sementes numa área, como por exemplo a estrutura da vegetação (Strykstra et al. 1998) e sua atratividade à fauna (Mc Donnell \& Stiles 1983, Parrota et al. 1997b), a distância (van Ruremonde \& Kalkhoven 1991, Parrota et al. 1997a e 1997b, Stampfli \& Zeiter 1999) e o grau de isolamento da área restaurada à fonte de propágulos (Peterken \& Game 1984, Wunderle Jr. 1997) e a condição das áreas que servem como fontes colonizadoras (Parrota et al. 1997b).

As características da paisagem na qual está inserida a área também podem facilitar ou inibir o processo de dispersão (Noss \& Harris 1986, Wunderle Jr. 1997). McClanahan (1986) e Robinson \& Handel (1993) ressaltam a importância de fontes colonizadoras para auxiliar o processo de sucessão, cuja existência pode ser limitada em paisagens degradadas (Wunderle Jr. 1997). 
Dificuldades na dispersão também podem causar problemas para a conservação de espécies raras, uma vez que elas não são especializadas nem na longevidade das sementes, nem na dispersão a longas distâncias (Strykstra et al: 1998).

$\mathrm{O}$ processo de dispersão por si só, no entanto, não garante o sucesso da regeneração. É preciso que as condições do solo, o microclima e a relação com os predadores sejam apropriadas para o estabelecimento das sementes (McClanahan \& Wolfe 1993). Nos trópicos, grande parte das sementes são consumidas por predadores (Holl \& Lullow 1997).

As sementes sobreviventes vão originar o banco de sementes do solo, outro processo responsável pela existência de propágulos numa área (Strykstra et al. 1998) e pela determinação do potencial da restauração (Bakker \& Berendese 1999). Este banco pode conter tanto espécies presentes quanto ausentes na área, e pode exercer uma forte influência na vegetação futura (Brown 1992).

Além da dispersão e da predação de sementes, uma série de outros fatores podem interferir na regeneração natural e, conseqüentemente, no sucesso da restauração de uma área, como o histórico do uso da terra (Guariguata et al. 1995), as condições iniciais do local, o modelo de plantio (espécies, densidade etc.), as práticas de manejo (Parrota 1993 e 1995, Wunderle Jr. 1997), a ausência de fungos ou bactérias simbiontes (Parrota 1993), a herbivoria de plântulas, a competição com gramíneas agreśsoras, a seca; a baixa fertilidade e a compactação do solo (Parrota 1993, Holl \& Kappelle 1999).

Vale ressaltar que a regeneração não se restringe somente a espécies arbóreas. O recrutamento de outras formas de vida, como as lianas, também pode ser crítico para a criação da estrutura semelhante a uma floresta natural tropical (Tucker \& Murphy 1997).

A questão genética também deve ser considerada na implantação de um projeto de restauração. A diversidade genética das populações introduzidas na restauração de uma área e sua variação ao longo do tempo podem afetar as taxas de endogamia e comprometer o sucesso da restauração a longo prazo (Montalvo et al. 1997, Lesica \& Allendorf 1999).

Enfim, o sucesso da restauração depende da compreensão sobre o funcionamento dos ecossistemas (Lugo 1997) e de capacidade de utilizar este 
conhecimento na montagem do quebra-cabeças. São muitos os fatores que influem neste processo e muitas considerações a serem feitas na implantação de um projeto. É preciso que os objetivos estejam claramente definidos (Jackson et al. 1995, Kondolf 1995), bem como a metodologia para avaliar se tais objetivos foram alcançados.

Vale ressaltar que a restauração não deve ser vista como substituta das práticas e das idéias conservacionistas, extremamente importantes na minimização das perdas da diversidade biológica (Young 2000), mas sim como um recurso importante na criação e na melhoria dos habitats para a preservação de espécies animais e vegetais. 


\section{METODOLOGIA}

\subsection{Caracterização da área de estudo}

\subsubsection{Localização geográfica e características edafo-climáticas}

A área de estudo está localizada no Pontal do Paranapanema, extremo oeste do Estado de São Paulo, entre as coordenadas $22^{\circ} 15^{\prime}$ e $23^{\circ} 00^{\prime} \mathrm{S}$ e $51^{\circ} 30^{\prime}$ e $53^{\circ} 00^{\prime} \mathrm{O}$ (Diegues 1990), fazendo parte da bacia do rio Paraná (ITESP 1998a).

A topografia da região varia de plana a ondulada, com altitude média de $300 \mathrm{~m}$ (Governo do Estado de São Paulo 1978).

A região apresenta solos formados a partir do grupo Bauru do Mesozóico, com arenito de origem sedimentar. Estes solos têm como principal característica a elevada concentração de areias, baixa fertilidade, boa permeabilidade e drenagem excessiva (ITESP 1998a). Na área de estudo, o solo predominante é o Latossolo Vermelho Escuro distrófico (Diegues 1990).

O clima, segundo a classificação de Köppen, obedece a dois tipos: Aw e Cwa, tropical de altitude com inverno seco e verão quente e chuvoso (ITESP 1998b). A temperatura média anual é de $21^{\circ} \mathrm{C}$, com valores mais baixos entre maio e agosto $\left(13^{\circ} \mathrm{C}\right)$ e mais altos entre janeiro e março $\left(32^{\circ} \mathrm{C}\right)$ e a pluviosidade varia em torno de 1100 a 1300 $\mathrm{mm} / \mathrm{ano}$ (Diegues, 1990). 


\subsubsection{Vegetação}

A formação florestal predominante é classificada como Floresta Estacional Semidecidual (Veloso et al. 1991), com algumas manchas de cerrado (ITESP 1998a).

A vegetação natural da região foi intensamente degradada, restando alguns poucos remanescentes, que por sua vez já sofreram algum tipo de interferência, como fogo ou retirada seletiva de madeira (ITESP 1998a). De acordo com dados da Secretaria de Agricultura e Abastecimento - CEEDESA/DDA (ITESP 1998a), em 1991, a maior parte das terras era ocupada com pastagens ( $71 \%$ ), sendo apenas $10,82 \%$ ocupados com áreas florestais.

O Parque Estadual do Morro do Diabo, com cerca de $34 \mathrm{mil} \mathrm{ha,} \mathrm{representa} \mathrm{hoje}$ o principal remanescente florestal da região, abrigando espécies animais em extinção, como o mico-leão preto (Leonthopithecus chrysopygus) e a anta (Tapirus terrestris), entre outros (ITESP 1998a).

\subsubsection{Caracterização das áreas restauradas}

A implantação das usinas hidroelétricas pela CESP (Companhia Energética do Estado de São Paulo) causou um grande impacto ambiental devido à submersão de importantes formações vegetais, refletindo na extinção local de espécies animais e vegetais, além de causar sérias alterações nos ecossistemas. A partir deste quadro e dos problemas operacionais causados pela ausência da vegetação nas margens de seus reservatórios, a CESP iniciou o processo de reflorestamento de suas áreas, sendo uma das pioneiras na implantação de reflorestamentos mistos com espécies nativas (CESP ' 1992).

Em virtude do processo de privatização das companhias geradoras de energia no Estado de São Paulo, as áreas estudadas pertencem atualmente à Duke Energy International, Geração Paranapanema S/A. 
Embora nos reflorestamentos não se tenha utilizado o conceito de restauração propriamente dito, estas áreas se constituem excelentes laboratórios naturais para o estudo das comunidades vegetais e da dinâmica das florestas.

As áreas estudadas situam-se nos municípios de Primavera, no Estado de São Paulo (Usina Hidroelétrica de Rosana) e Itaguajé, no Paraná (Usina Hidroelétrica de Taquaruçu), nas margens dos lagos formados pelo represamento do Rio Paranapanema (Figuras 1 e 2).

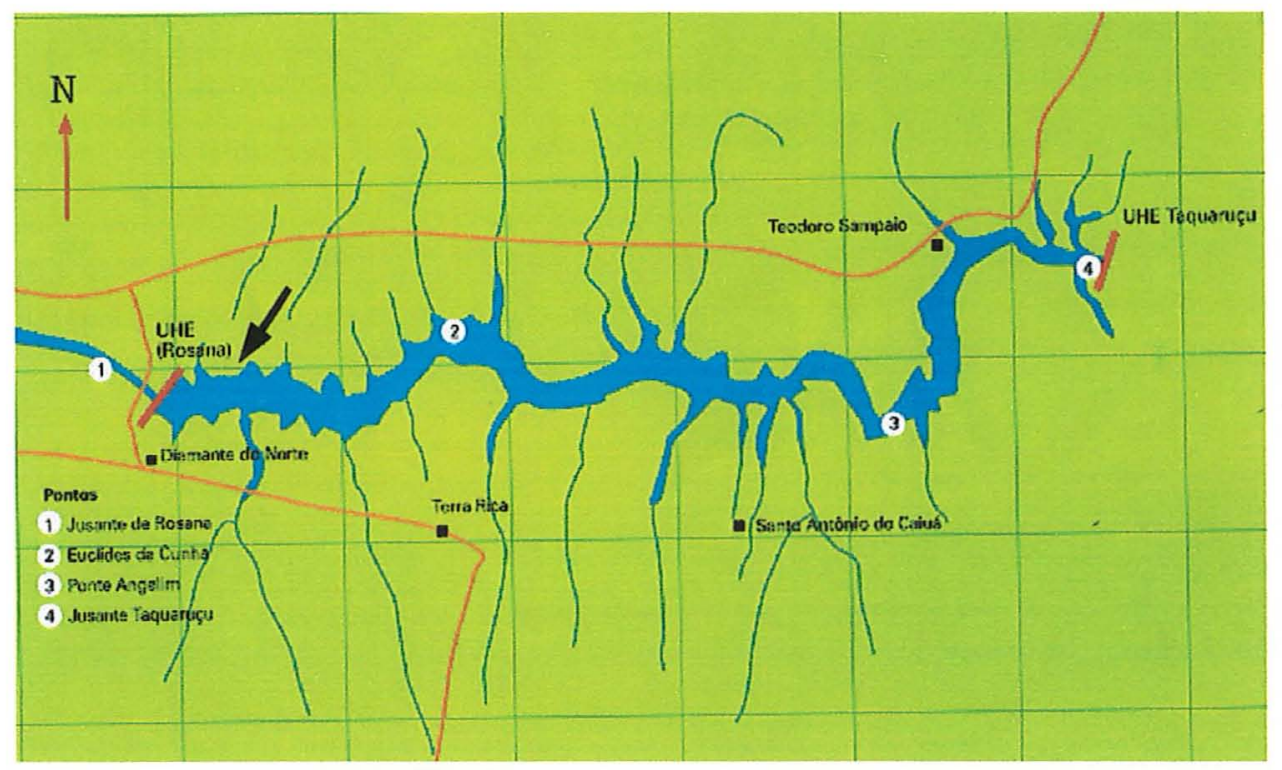

Figura 1. Esquema ilustrativo da barragem da Usina Hidroelétrica de Rosana. A seta preta indica o local das áreas reflorestadas estudadas.

O reflorestamento da barragem de Rosana tem cerca de 300 ha e engloba plantações de 1988 até 1991. Além da heterogeneidade de idades, existem ainda três situações de perturbação distintas: as áreas de empréstimo, caracterizadas pela retirada de grandes camadas de solo para a construção da barragem; as áreas ciliares, situadas nas margens do reservatório e a porção restante que se encontra fora da faixa ciliar e das áreas de empréstimo. 


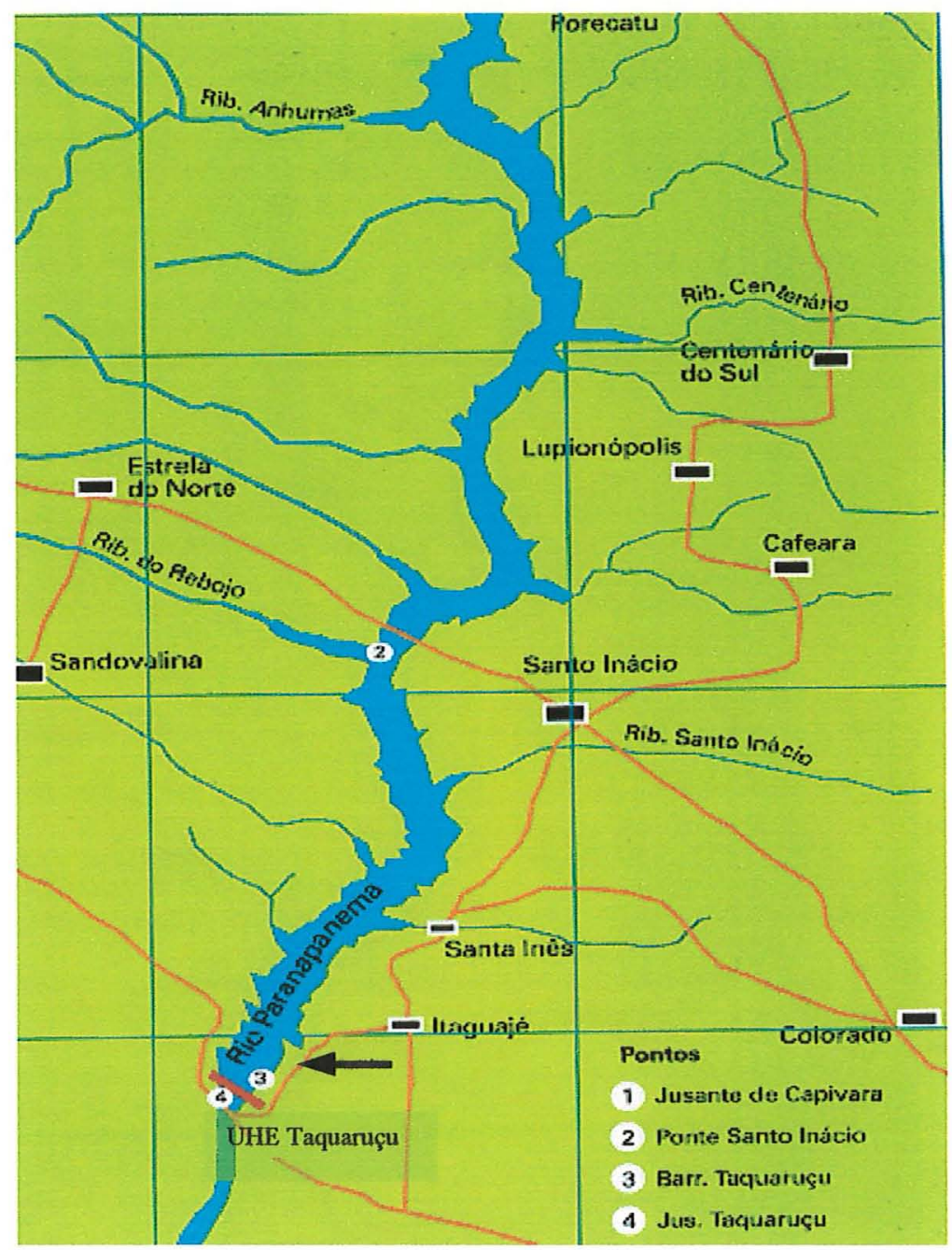

Figura 2. Esquema ilustrativo da barragem da Usina Hidroelétrica de Taquaruçu. A seta preta indica o local da área reflorestada estudada.

Tendo em vista a provável interferência desses fatores no desenvolvimento da floresta, optou-se por direcionar a pesquisa para uma única situação de perturbação, uma vez que a grande variação dos fatores bióticos e abióticos entre as situações poderia dificultar a interpretação dos resultados. Assim, as áreas selecionadas para o estudo (tanto na barragem de Rosana quanto na barragem de Taquaruçu) compreendem apenas a faixa ciliar dos reflorestamentos, situadas nas margens dos reservatórios. 
$\mathrm{Na}$ Usina de Rosana, foram estudadas áreas reflorestadas em 1988 e 1989. A principal diferença entre estas áreas está na proporção de árvores plantadas segundo os grupos ecológicos. Em 1988, os conceitos de șucessão secundária ainda não eram utilizados nos modelos de revegetação. Isso não significa que não tenham sido contemplados todos os grupos ecológicos no plantio, mas sim que a proporção dos indivíduos de acordo com tais grupos não obedeceu a nenhuma regra específica. Foi a partir de 1989 que os modelos de revegetação utilizados pela Companhia fundamentaram-se nos conceitos de sucessão secundária (grupos ecológicos segundo Budowski 1965), com a utilização predominante de espécies pioneiras (Kageyama \& Gandara, no prelo).

Na barragem de Taquaruçu, cuja área é de 150 ha, os reflorestamentos estudados foram realizados em 1993. Do mesmo modo que a área plantada em 1989, foram utilizados predominantemente indivíduos de espécies pioneiras nos modelos de revegetação.

Assim, a principal característica que diferencia as áreas estudadas é o modelo de plantio utilizado, havendo muito mais árvores pioneiras nas áreas plantadas em 1989 e 1993 do que na área plantada em 1988. Os detalhes das características de cada plantio e as proporções de indivíduos plantados de acordo com os grupos ecológicos são apresentados nas tabelas 1 e 2 .

Tabela 1. Características de plantio das áreas de estudo.

\begin{tabular}{lccc}
\hline \multirow{2}{*}{ Características das áreas } & \multicolumn{3}{c}{ Ano de plantio } \\
\cline { 2 - 4 } & 1988 & 1989 & 1993 \\
\hline Densidade de plantio (árvores/ha) & 2.247 & 2.744 & 2.078 \\
Espaçamento aproximado (m) & $3,0 \times 1,5$ & $2,0 \times 2,0$ & $2,0 \times 2,3$ \\
Falhas após o replantio (\%) & 9 & 7,6 & 10,8 \\
Número de espécies plantadas & $\underline{42}$ & $\underline{39}$ & $3 \underline{3}$ \\
\hline
\end{tabular}


É importante destacar que a Companhia utiliza uma nomenclatura na qual as espécies pioneiras e secundárias iniciais são agrupadas em uma única categoria, denominada genericamente de "pioneiras" (P), sendo que as secundárias tardias e climácicas são reunidas em um grupo chamado de "não-pioneiras"(NP) (Kageyama \& Gandara, no prelo).

Tabela 2. Número de espécies e proporção do número de indivíduos plantados segundo os grupos ecológicos e as idades de plantio.

\begin{tabular}{|c|c|c|c|c|}
\hline & \multirow[b]{2}{*}{ Grupo ecológico } & \multicolumn{3}{|c|}{ Ano de plantio } \\
\hline & & 1988 & 1989 & 1993 \\
\hline \multirow{5}{*}{$\begin{array}{l}\text { Número de } \\
\text { espécies }\end{array}$} & Pioneiras & 4 & 4 & 5 \\
\hline & Secundárias iniciais & 14 & 19 & 16 \\
\hline & Secundárias tardias & 9 & 8 & 10 \\
\hline & Climácicas & 14 & 8 & 7 \\
\hline & Sem caracterização & 1 & 0 & 0 \\
\hline \multirow{5}{*}{$\begin{array}{l}\text { Proporção do } \\
\text { número de } \\
\text { indivíduos (\%) }\end{array}$} & Pioneiras & 20,2 & 50,4 & 57,3 \\
\hline & Secundárias iniciais & 38 & 30,6 & 27,2 \\
\hline & Secundárias tardias & 16,8 & 9,4 & 11,8 \\
\hline & Climácicas & 24,8 & 9,6 & 3,6 \\
\hline & Sem caracterização & 0,1 & 0 & 0 \\
\hline
\end{tabular}

Toda a área de Rosana era originalmente ocupada com pastagem. Atualmente, no seu entorno ainda predominam áreas de pasto (Figura 3), existindo, na outra margem do reservatório, uma área de mata natural pertencente à Estação Ecológica dos Caiuás. $\mathrm{Na}$ área de Taquaruçu, a condição de vizinhança da área reflorestada é semelhante à de Rosana, com predomínio de pastagens (Figura 4). 


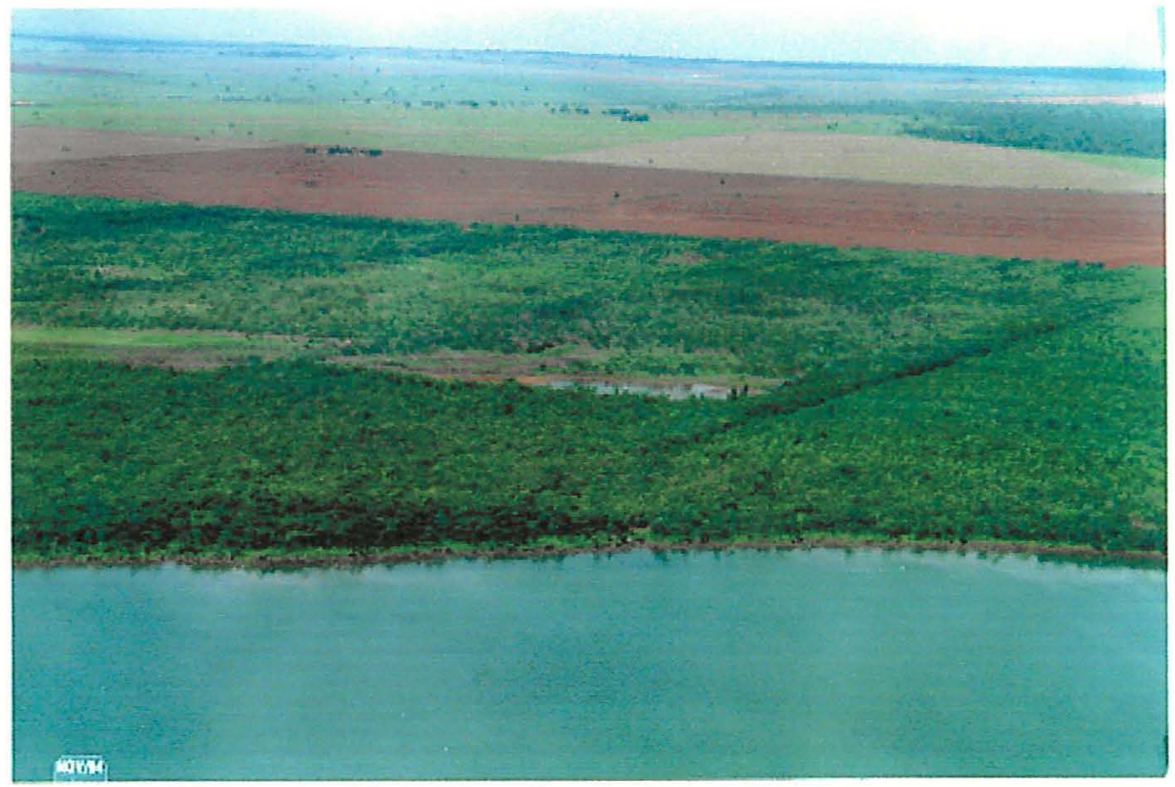

Figura 3. Vista aérea do reflorestamento às margens da represa de Rosana, no município de Primavera (SP), com extensa área de pasto ao fundo.

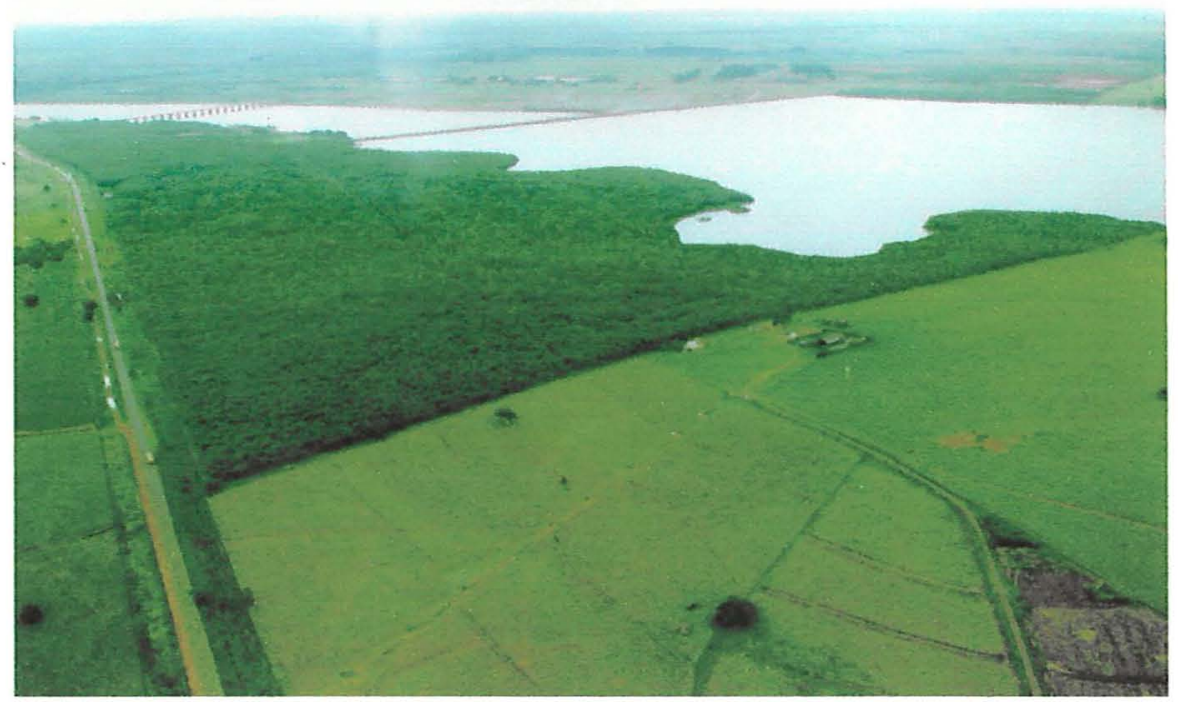

Figura 4. Vista aérea do reflorestamento às margens da represa de Taquaruçu, no município de Itaguagé (PR), com área de pastagem vizinha ao reflorestamento em primeiro plano. 


\subsection{Levantamento do estrato arbóreo}

\subsubsection{Composição, estrutura e dinâmica}

Para o estudo da composição, estrutura e dinâmica do estrato arbóreo, foram instaladas parcelas permanentes de $30 \times 30 \mathrm{~m}\left(900 \mathrm{~m}^{2}\right)$, demarcadas com tubos de PVC e distribuídas aleatoriamente dentro da área delimitada para o estudo. Foram instaladas quatro parcelas na área plantada em 1988, duas parcelas na área plantada em 1989 e três parcelas na área plantada em 1993.

Em virtude da ausência de mapas completos e atualizados das áreas reflorestadas na barragem de Rosana (plantios de 1988 e 1989), acreditou-se que as parcelas estavam igualmente distribuídas de acordo com as idades de plantio, isto é, três parcelas por idade. Posteriormente, com a atualização de informações de funcionários da CESP, constatou-se que haviam sido alocadas quatro parcelas na área plantada em 1988, e duas na área plantada em 1989, o que tornou a amostragem desigual.

O primeiro levantamento foi realizado em julho de 1998, quando as áreas tinham então aproximadamente 10 (plantio de 1988), nove (plantio de 1989) e cinco (plantio de 1993) anos.

Dentro de cada parcela foram amostrados todos os indivíduos com circunferência à altura do peito (CAP) igual ou superior a $15 \mathrm{~cm}$, plantados ou provenientes da regeneração natural. Estes indivíduos foram numerados com plaquetas de alumínio, possibilitando, assim, a remedição dos mesmos um ano após o primeiro levantamento, para o estudo da dinâmica das comunidades.

A identificação dos indivíduos pertencentes ao estrato arbóreo (CAP $\geq 15 \mathrm{~cm})$ e provenientes da regeneração natural foi possível por estarem estes indivíduos claramente fora do alinhamento ou do espaçamento utilizado nos plantios. As plantas com CAP inferior a $15 \mathrm{~cm}$, assim como as falhas e as plantas mortas encontradas já no primeiro levantamento, foram também registradas e identificadas para complementar a caracterização estrutural das áreas. 
No levantamento, foram registrados o CAP, a altura total (com o auxílio de uma vara telescópica graduada) e a classe de copa, referente à posição da copa no dossel, de acordo com a seguinte classificação:

- Classe 1 - copa emergente (copa acima do dossel);

- Classe 2 - copa de dossel (copa forma o dossel);

- Classe 3 - copa de sub-dossel (copa abaixo do dossel, mas não totalmente sombreada);

- Classe 4 - copa de sub-bosque (copa totalmente abaixo do dossel, recebendo somente luz indireta).

Os indivíduos foram identificados através de coletas de material botânico e comparação em herbário, além de consultas a especialistas das respectivas famílias ou gêneros. O sistema adotado para a classificação das famílias foi o de Cronquist (1981).

As espécies foram classificadas segundo os grupos ecológicos propostos por Budowski (1965) (pioneiras, secundárias iniciais, secundárias tardias e climácicas), seguindo prioritariamente a classificação já feita pela CESP, além de consultas a literatura (Grombone-Guaratini 1998).

A partir deste levantamento foram calculados os índices de diversidade de Shannon (H') e equabilidade (J) de acordo com Pielou (1975) e Magurran (1988):

$$
\mathrm{H}^{\prime}=-\sum_{\mathrm{i}=1}^{\mathrm{s}} \mathrm{p}_{\mathrm{i}} \ln \mathrm{p}_{\mathrm{i}}
$$

Onde,

$H^{\prime}=$ Índice de diversidade de Shannon

$p_{i}=n_{i} / N$

$n_{i}=$ número de indivíduos da espécie $i$

$N=$ número total de indivíduos amostrados 


$$
J=H^{\prime} / H_{\text {máx }}
$$

Onde,

$J=$ Índice de equabilidade

$H_{\text {máx }}=\ln S$

$S=$ número de espécies

\subsubsection{Densidade de copa e plantas herbáceas}

Tanto para o levantamento da densidade de copa quanto de espécies herbáceas (predominantemente capim colonião - Panicum maximum L.), utilizou-se um densitômetro vertical (GRS Densitometer), através do qual registrou-se a presença/ausência de cobertura em pontos distribuídos de $1 \mathrm{em} 1 \mathrm{~m}$ ao longo de cinco transectos dentro de cada parcela. Em média, foram amostrados 112 pontos por parcela.

Esta metodologia é recomendada para estudos comparativos, principalmente para áreas relativamente grandes e apresenta uma grande vantagem pelo baixo custo (Stumpf 1993) e pela sua praticidade em campo.

A distribuição dos transectos foi feita conforme metodologia descrita por Stumpf (1993), de maneira que não houvesse influência das linhas de plantio na amostragem (Figura 5), já que a maior entrada de luz proporcionada pelo espaçamento poderia influenciar a densidade de copa e a presença de espécies herbáceas.

O levantamento da densidade de copa foi realizado em duas épocas do ano (inverno e verão), com o intuito de detectar alterações da entrada de luz no interior da floresta, em virtude da queda das folhas de algumas espécies. 


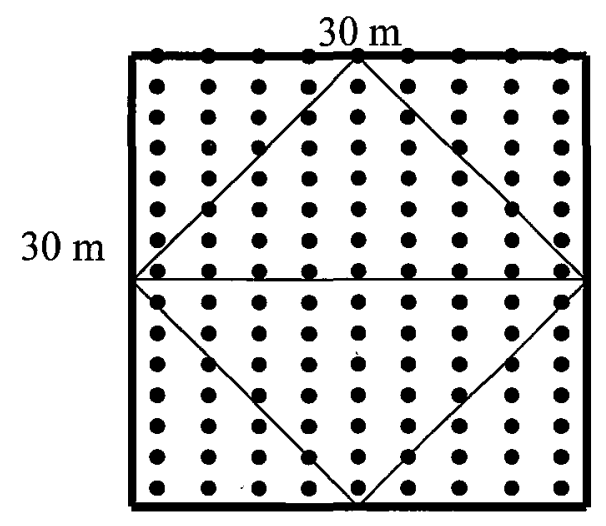

Figura 5. Esquema dos transectos de amostragem da densidade de copa e de plantas herbáceas utilizados nas parcelas de amostragem do estrato arbóreo. A linha mais grossa representa a parcela; as linhas finas representam os cinco transectos e os círculos representam as árvores plantadas.

\subsection{Levantamento da regeneração natural}

Para a avaliação da regeneração natural, as parcelas de $900 \mathrm{~m}^{2}$ utilizadas para o levantamento do estrato arbóreo foram sub-amostradas com seis sub-parcelas circulares de $1 \mathrm{~m}$ de raio $\left(3,14 \mathrm{~m}^{2}\right)$, demarcadas aleatoriamente, num total de 54 sub-parcelas.

Dentro de cada sub-parcela foram registrados o número (densidade) e a altura dos indivíduos lenhosos com CAP inferior a $15 \mathrm{~cm}$ e altura igual ou superior a $50 \mathrm{~cm}$. Vale lembrar que os indivíduos provenientes da regeneração natural, mas com CAP $\geq 15$ $\mathrm{cm}$ foram amostrados no levantamento do estrato arbóreo.

Embora a altura mínima determinada para a inclusão das plantas em regeneração na amostragem $(50 \mathrm{~cm})$ possa restringir o número de indivíduos, principalmente na área mais jovem, esta foi escolhida por acreditar-se que tais indivíduos já estejam estabelecidos, constituindo-se assim, elementos importantes para a perpetuação da floresta.

Para o estudo da dinâmica, novas sub-parcelas foram sorteadas um ano após o primeiro levantamento e as mesmas medidas foram registradas. 


\section{RESULTADOS E DISCUSSÃO}

\subsection{Estrato arbóreo}

\subsubsection{Composição florística e diversidade}

A Tabela 3 apresenta uma comparação de características da composição florística das três áreas reflorestadas (indivíduos com CAP $\geq 15 \mathrm{~cm}$, plantados e provenientes da regeneração natural) com a composição do Parque Estadual do Morro do Diabo (Schlittler et al. 1995), que representa o maior remanescente de Floresta Estacional Semidecidual no Pontal do Paranapanema, com uma área de cerca de 34.000 ha. No levantamento feito por Schlittler et al. (1995), o critério de inclusão para a amostragem dos indivíduos foi muito próximo ao deste estudo, tendo sido amostrados todos os indivíduos com DAP $\geq 5 \mathrm{~cm}$.

A lista geral das espécies amostradas com os respectivos grupos ecológicos encontram-se no anexo A.

Tabela 3. Aspectos gerais da composição florística das áreas reflorestadas em comparação com a vegetação do Parque Estadual do Morro do Diabo.

\begin{tabular}{lcccc}
\hline & \multicolumn{3}{c}{ Ano de plantio } & \multicolumn{2}{c}{ Morro do Diabo } \\
& 1988 & 1989 & 1993 & (Schlittler et al. 1995) \\
\hline Total de indivíduos amostrados & 546 & 299 & 385 & 1140 \\
Número de espécies & 37 & 32 & 27 & 104 \\
Número de gêneros & 34 & 29 & 22 & 84 \\
Número de famílias & 20 & 18 & 14 & 37 \\
\hline
\end{tabular}


As famílias predominantes na área plantada em 1988 foram Fabaceae (seis espécies) e Mimosaceae (quatro espécies). Na área plantada em 1989 foram Mimosaceae (seis espécies) e Fabaceae (cinco espécies) e na área plantada em 1993, Mimosaceae (seis espécies). No levantamento feito por Schlittler et al. (1995), também predominaram Mimosaceae (10 espécies) e Fabaceae (nove espécies).

O número de espécies encontrado nas áreas reflorestadas está bastante aquém do número encontrado no ambiente natural. Apesar de haver uma grande diferença no número de indivíduos amostrados, o número de espécies encontradas nas áreas reflorestadas não deve aumentar significativamente com o aumento da intensidade amostral, por se tratar de áreas plantadas. Isto pode ser claramente observado comparando-se as áreas reflorestadas em 1988 e 1989, nas quais, apesar da grande diferença no número de indivíduos amostrados, o número de espécies encontradas é semelhante.

A maior riqueza observada no Morro do Diabo pode ser explicada pela presença de um grande número de espécies ocorrendo em baixas densidades, característica da floresta tropical (Hartshorn 1980). Este aspecto já vem sendo estudado e incorporado em experimentos com modelos de reflorestamento (Kageyama et al. 1994), com o intuito de aumentar a similaridade entre as áreas restauradas e a floresta natural.

Embora o baixo número de espécies nas áreas reflorestadas seja justificável pelas dificuldades operacionais, comuns em reflorestamentos de grande escala, ele pode ser um fator de comprometimento da diversidade da floresta daqui a alguns anos, se a colonização das áreas por outras espécies não estiver ocorrendo de maneira razoável. Para a manutenção ou aumento da diversidade nessas áreas, é de extrema importância que novas espécies estejam chegando e se estabelecendo, e que as espécies presentes consigam se regenerar, formando um banco de plântulas que será responsável pela perpetuação dessas florestas.

No entanto, devido à intensa fragmentação das florestas naturais, principalmente no Estado de São Paulo (Victor 1975), a proximidade de áreas restauradas em relação a outros remanescentes florestais é uma condição pouco 
freqüente. Sendo assim, a colonização das áreas restauradas por propágulos externos não deve ser tomada como processo determinante na perpetuação das áreas restauradas.

Uma alternativa a esta condição é a utilização de uma alta riqueza na implantação dos projetos de restauração. Rodrigues (1999) ressalta a importância de utilizar-se um grande número de espécies em projetos de restauração e afirma que as chances de sucesso destes projetos podem ser ampliadas se a diversidade dos remanescentes florestais da região for considerada na seleção das espécies, principalmente em regiões onde a vegetação encontra-se muito fragmentada.

A tabela 4 apresenta os índices de diversidade de Shannon e Equabilidade em comparação com outros trabalhos realizados em Florestas Estacionais Semideciduais no Estado de São Paulo, cujas áreas inserem-se no Planalto Ocidental Paulista e na Depressão Periférica (Rodrigues 1999). Os trabalhos utilizados para a comparação apresentam o critério de inclusão dos indivíduos semelhante ao do presente estudo, variando entre 4,78 e $5 \mathrm{~cm}$ de DAP.

A partir da tabela 4, nota-se que a área plantada em 1988 (com 10 anos na época do levantamento), cujo modelo de plantio não levou em consideração os princípios da sucessão secundária, é a que apresenta os valores de diversidade e equabilidade mais semelhantes aos encontrados em Florestas Estacionais Semideciduais no Estado de São Paulo.

Comparando tais valores com os encontrados por Schlittler et al. (1995) no Morro do Diabo, que é o remanescente mais próximo à área de estudo, a diferença se acentua, principalmente para as áreas plantadas em 1989 (com nove anos) e 1993 (com cinco anos). Os valores apresentados para estas áreas assemelham-se aos encontrados por Pinto (1989) e Fonseca (1998), que por sua vez discutem em seus trabalhos as possíveis causas de valores tão baixos. Pinto (1989) justifica a baixa diversidade pelo pequeno tamanho e pelo elevado grau de distúrbio da floresta estudada. Fonseca (1998) atribui a baixa equabilidade à influência de três espécies encontradas em seu levantamento. 
Tabela 4. Índices de diversidade de Shannon $\left(\mathrm{H}^{\prime}\right)$ e Equabilidade (J) para as três áreas de estudo em comparação com outros trabalhos em Florestas Estacionais Semideciduais no Estado de São Paulo.

\begin{tabular}{llcc}
\hline \multicolumn{1}{c}{ Referência } & \multicolumn{1}{c}{ Área de estudo } & $\mathrm{H}^{\prime}$ & $\mathrm{J}$ \\
\hline Área plantada em 1988 (10 anos) & Primavera & 3,03 & 0,84 \\
Área plantada em 1989 (9 anos) & Primavera & 2,45 & 0,71 \\
Área plantada em 1993 (5 anos) & Itaguajé & 2,18 & 0,66 \\
\hline Schlittler et al. (1995) & Teodoro Sampaio & 4,02 & $0,87^{*}$ \\
Penha (1998) & Campinas & 3,74 & 0,84 \\
Kotchetkoff-Henriques \& Joly (1994) & Itirapina & 3,61 & 0,81 \\
Rodrigues (1991) & Ipeúna & 3,50 & - \\
Rozza (1997) & Matão & 3,24 & 0,71 \\
Pinto (1989) & Jaboticabal & 3,05 & $0,70^{*}$ \\
Fonseca (1998) & Botucatu & 2,72 & 0,66 \\
\hline
\end{tabular}

*Valores calculados (não apresentados no trabalho)

Baixos valores de equabilidade indicam uma desigualdade na densidade de indivíduos por espécie, sugerindo que a floresta esteja sendo "dominada" por algumas poucas espécies com um grande número de indivíduos.

A partir dos valores de densidade relativa das espécies para cada área de estudo, confirma-se esta hipótese. Na área plantada em 1988, quatro espécies (Cecropia pachystachya Trécul, Croton floribundus (L.) Spreng., Genipa americana L. e Peltophorum dubium (Spreng.) Taub.) representam 44,5\% da densidade total do plantio. Já nas áreas plantadas em 1989 e 1993, cujos valores de equabilidade são mais baixos, apenas duas espécies correspondem a mais de $50 \%$ dos indivíduos plantados. $\mathrm{Na}$ área de 1989, predominam Croton floribundus e Cecropia pachystachya, somando 50,2\% de densidade relativa; na área plantada em 1993, Trema micrantha (L.) Blume e Guazuma ulmifolia Lam. representam $57,4 \%$ da densidade total do plantio.

É importante observar que, na maioria dos casos, as espécies predominantes são pioneiras (com exceção de Genipa americana e Peltophorum dubium). A alta densidade 
destas espécies pode exercer grande influência nos padrões de estabelecimento da regeneração natural e, conseqüentemente, na sustentabilidade das florestas, em virtude do processo de mortalidade desses indivíduos.

No que se refere à distribuição das espécies de acordo com os grupos ecológicos, houve predomínio de espécies secundárias iniciais em todas as áreas estudadas (Tabela 5).

Tabela 5. Distribuição do número de espécies (indivíduos com CAP $\geq 15 \mathrm{~cm}$, plantados e provenientes da regeneração natural) de acordo com os grupos ecológicos.

\begin{tabular}{ccccccc}
\hline \multirow{2}{*}{$\begin{array}{c}\text { Ano de } \\
\text { plantio }\end{array}$} & \multicolumn{5}{c}{ Grupo ecológico } & Total \\
\cline { 2 - 6 } & Pioneiras & $\begin{array}{c}\text { Secundárias } \\
\text { iniciais }\end{array}$ & $\begin{array}{c}\text { Secundárias } \\
\text { tardias }\end{array}$ & Climácicas & $\begin{array}{c}\text { Sem } \\
\text { caracterização }\end{array}$ \\
\hline 1988 & 5 & 15 & 6 & 9 & 2 & 37 \\
1989 & 5 & 15 & 5 & 6 & 1 & 32 \\
1993 & 5 & 13 & 7 & 2 & - & 27 \\
\hline
\end{tabular}

Comparando-se as espécies amostradas no levantamento do estrato arbóreo, no qual foram incluídos somente os indivíduos com CAP $\geq 15 \mathrm{~cm}$ (Tabela 5), com as espécies inicialmente plantadas (Tabela 2), observou-se o acréscimo de uma espécie do grupo das pioneiras nas áreas mais antigas (1988 e 1989). Na área plantada em 1988, este aumento foi devido à inclusão de Acrocomia aculeata (Jacq.) Lodd. ex Mart, espécie remanescente no local antes do plantio. Na área plantada em 1989, amostrou-se Sapium glandulatum (Vell.) Pax, espécie pioneira em regeneração naquela área.

Já para os demais grupos ecológicos, de maneira geral, o número de espécies amostradas no levantamento do estrato arbóreo foi menor que o número de espécies plantadas, já que algumas espécies ainda não atingiram $15 \mathrm{~cm}$ de CAP.

Para as áreas plantadas em 1988 e 1989, o grupo das pioneiras foi o que apresentou menor número de espécies. Esta situação se inverte quando se analisa a proporção do número de indivíduos, e não mais de espécies, em relação aos grupos ecológicos (Tabela 6). Principalmente para as áreas plantadas em 1989 e 1993, nas quais 
o modelo de plantio já contemplava alguns conceitos de sucessão secundária, o número de árvores pioneiras é superior ao número de árvores dos demais grupos. O grupo das espécies secundárias iniciais aparece em segundo lugar, seguido das secundárias tardias e das climácicas, que apresentam proporções bastante inferiores nestas áreas.

Tabela 6. Proporção do número de indivíduos (\%) amostrados no levantamento do estrato arbóreo (indivíduos com CAP $\geq 15 \mathrm{~cm}$, plantados e provenientes da regeneração natural) de acordo com os grupos ecológicos.

\begin{tabular}{cccccc}
\hline \multirow{2}{*}{$\begin{array}{c}\text { Ano de } \\
\text { plantio }\end{array}$} & Pioneiras & $\begin{array}{c}\text { Secundárias } \\
\text { iniciais }\end{array}$ & $\begin{array}{c}\text { Secundárias } \\
\text { tardias }\end{array}$ & Climácicas & $\begin{array}{c}\text { Sem } \\
\text { caracterização }\end{array}$ \\
\cline { 2 - 6 } 1988 & 28,7 & 34,4 & 14 & 22,5 & 0,4 \\
1989 & 64,4 & 25,5 & 5,3 & 4,5 & 0,3 \\
1993 & 72 & 22,6 & 4,9 & 0,5 & 0 \\
\hline
\end{tabular}

Já na área plantada em 1988, a distribuição dos indivíduos de acordo com os grupos ecológicos é mais uniforme, havendo uma grande diferença entre a proporção de árvores pioneiras, secundárias tardias e climácicas nesta área quando comparada às demais.

Com relação ao que foi originalmente plantado (Tabela 2), nota-se que as proporções do número de indivíduos do grupo das espécies pioneiras amostradas no levantamento (Tabela 6) foram superiores às observadas no plantio inicial. Para os demais grupos ecológicos, as proporções registradas no levantamento foram inferiores às proporções originais do plantio, pois muitas espécies ainda não atingiram o CAP mínímo para a inclusão na amostragem.

\subsubsection{Estrutura}

Analisando a estrutura da comunidade vegetal na época do primeiro levantamento (Tabela 7), verifica-se que os valores de área basal/indivíduo foram muito 
semelhantes entre as áreas com 10 e nove anos (plantios feitos em 1988 e 1989), sendo que a altura média das árvores foi superior na área com nove anos.

Tabela 7. Estrutura do estrato arbóreo (indivíduos com CAP $\geq 15 \mathrm{~cm}$, plantados e provenientes da regeneração natural) de acordo com as idades de plantio.

\begin{tabular}{lccc}
\hline \multicolumn{1}{c}{ Ano de plantio } & 1988 & 1989 & 1993 \\
& 10 & 9 & 5 \\
\hline Idade (anos) & 1.519 & 1.661 & 1.426 \\
Densidade total (indivíduos/ha) & 1.344 & 1.628 & 1.426 \\
Densidade dos indivíduos plantados (ind./ha) & 175 & 33 & 0 \\
Área basal $\left(\mathrm{m}^{2}\right)$ & 22,38 & 24,92 & 14,76 \\
Área basal/indivíduo $\left(\mathrm{m}^{2}\right)$ & 0,0147 & 0,0150 & 0,0103 \\
Altura total $(\mathrm{m})$ & 9,1 & 10,2 & 8,6 \\
\hline
\end{tabular}

Considerando-se somente a idade, esperava-se que o reflorestamento de 1988 apresentasse uma estrutura mais desenvolvida que o de 1989, com área basal e altura médias maiores, o que não ocorreu. Este fato deve-se provavelmente à diferença existente na composição de espécies de cada plantio.

$\mathrm{Na}$ área plantada em 1989, que apresentou maior altura média das árvores, a proporção dos indivíduos que pertencem ao grupo das espécies pioneiras é quase $36 \%$ superior à proporção encontrada na área plantada em 1988 (Tabela 6). Situação semelhante ocorre com relação à área plantada em 1993, que apesar da diferença de idade, apresentou valores de área basal/indivíduo e altura média pouco menores que os encontrados nas demais áreas. Novamente estes valores podem ser explicados pela maior proporção de árvores pioneiras encontradas nesta área (cerca de $43 \%$ maior que na área plantada em 1988).

Esta influência pode ser melhor observada nas figuras 6 e 7, que mostram que os maiores valores de altura e área basal concentram-se no grupo das espécies pioneiras, principalmente nas áreas onde este grupo é predominante (plantios de 1989 e 1993). 


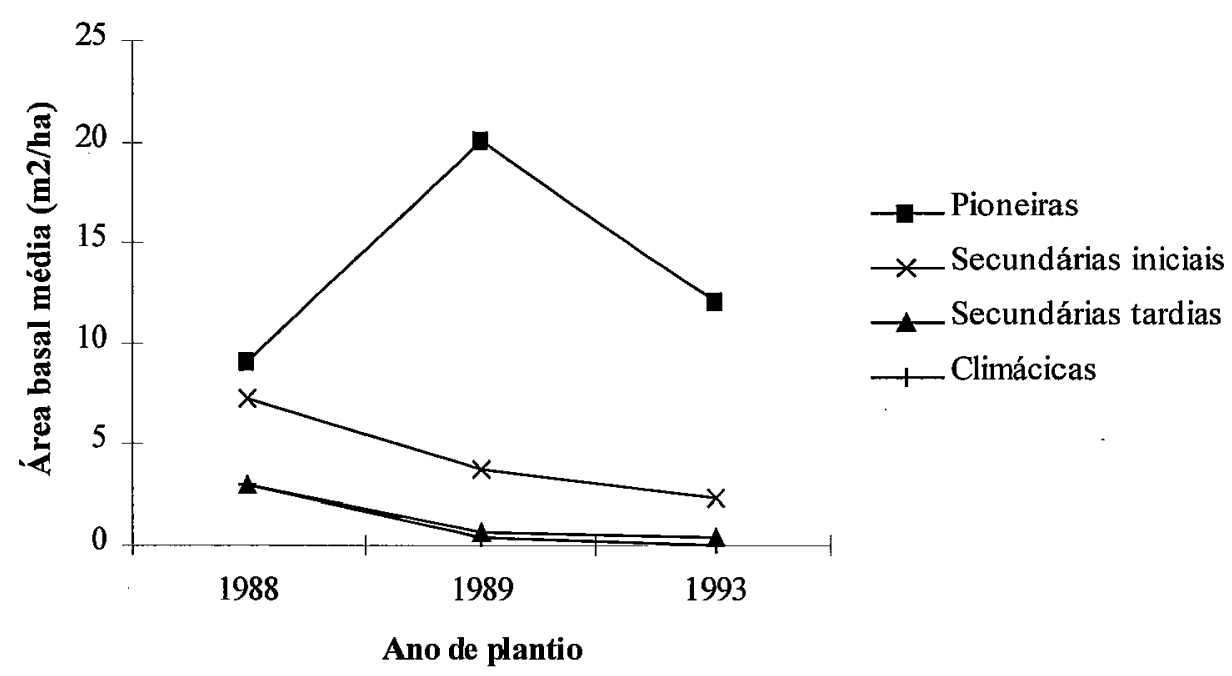

Figura 6. Distribuição dos valores de área basal média (indivíduos com $\mathrm{CAP} \geq 15 \mathrm{~cm}$, plantados e provenientes da regeneração natural) de acordo com os grupos ecológicos e as idades de plantio.

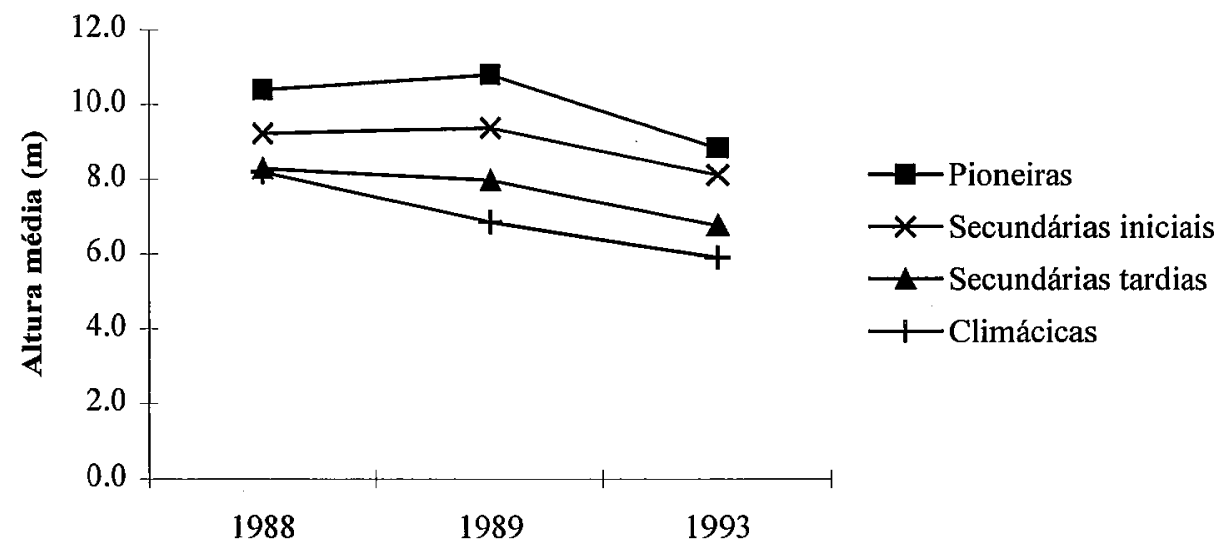

Ano de plantio

Figura 7. Distribuição dos valores de altura média (indivíduos com $C A P \geq 15 \mathrm{~cm}$, plantados e provenientes da regeneração natural) de acordo com os grupos ecológicos e as idades de plantio. 
No que se refere às árvores mortas amostradas no primeiro levantamento, registrou-se 7,4 \% na área plantada em 1988, 10,4\% na área plantada em 1989 e apenas 0,4\% na área plantada em 1993. Este baixo valor observado no plantio de 1993 deve-se provavelmente ao fato de a área ser ainda muito jovem (cinco anos), idade que corresponde ao início do processo de mortalidade das espécies pioneiras (Budowski 1965). Já o maior valor observado na área plantada em 1989 parece estar novamente relacionado à maior proporção de indivíduos de espécies pioneiras plantadas nesta área.

Foram observados também os indivíduos plantados que não atingiram o CAP mínimo para inclusão no levantamento do estrato arbóreo $(15 \mathrm{~cm})$. Em relação ao número total de indivíduos registrados em cada parcela (plantados e provenientes da regeneração natural com $\mathrm{CAP} \geq 15 \mathrm{~cm}$, mais os indivíduos plantados com $\mathrm{CAP}$ inferior a $15 \mathrm{~cm}$ ), estes indivíduos representaram $25,7 \%, 27,7 \%$ e $22,5 \%$ para as áreas plantadas em 1988, 1989 e 1993, respectivamente. Nota-se que a área mais jovem (1993) foi a que apresentou menor proporção destes indivíduos. No entanto, esta também é a área com maior proporção de indivíduos do grupo das pioneiras (72\%), responsáveis pelo desenvolvimento mais rápido da floresta.

Esta relação do predomínio de espécies pioneiras com o desenvolvimento da estrutura da floresta vem confirmar algumas das características mais marcantes deste grupo ecológico, como o rápido crescimento e o ciclo vida curto (Budowski 1965), já bastante discutidos na literatura.

A figura 8 apresenta os resultados da classificação dos indivíduos em classes de copa. Nota-se que as classes se sobrepõem, formando um contínuo decrescente de alturas, indicando que esta classificação pode ser usada como uma ferramenta adicional na análise da estrutura da comunidade. Na classe 1, encontram-se os indivíduos cujas copas estão acima do dossel (copa emergente); na classe 2, os indivíduos cujas copas formam o dossel (copa de dossel); na classe 3, os indivíduos cujas copas estão abaixo do dossel (copa de sub-dossel), mas não totalmente sombreadas e na classe 4, os indivíduos cujas copas ficam totalmente abaixo do dossel, recebendo somente luz indireta (copa de sub-bosque). 


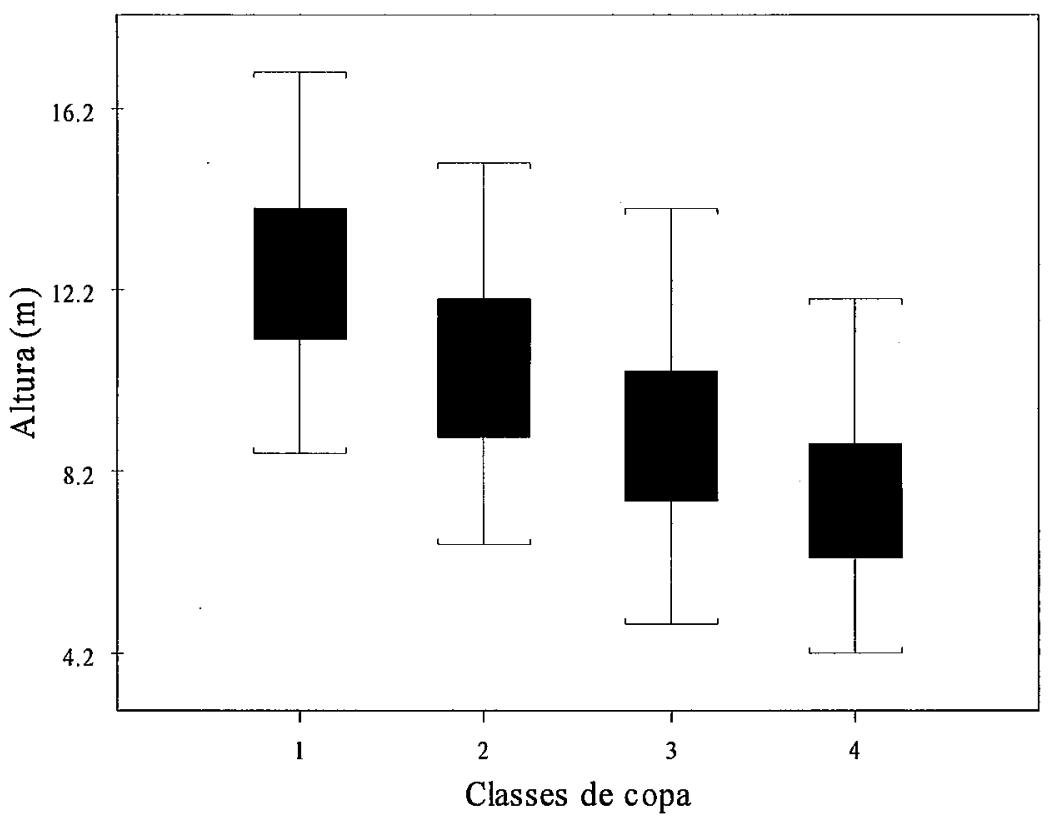

Figura 8. "Boxplot" da distribuição dos indivíduos nas classes de copa de acordo com a altura. Classes de copa: classe 1 - copa emergente; classe 2 - copa de dossel; classe 3 copa de sub-dossel; classe 4 - copa de sub-bosque. Os retângulos delimitam $50 \%$ das observações; a linha interna representa a mediana e as barras indicam a amplitude dos dados.

A figura 9 mostra a distribuição dos indivíduos nas classes de copa, dando uma idéia da estratificação da floresta para cada idade de plantio.

Observa-se que a estratificação da floresta é bastante semelhante entre as áreas plantadas em 1988 e 1989. Nestas áreas predominam as árvores de menor porte (classe 4), cujas copas encontram-se totalmente na sombra e recebem somente luz indireta. 


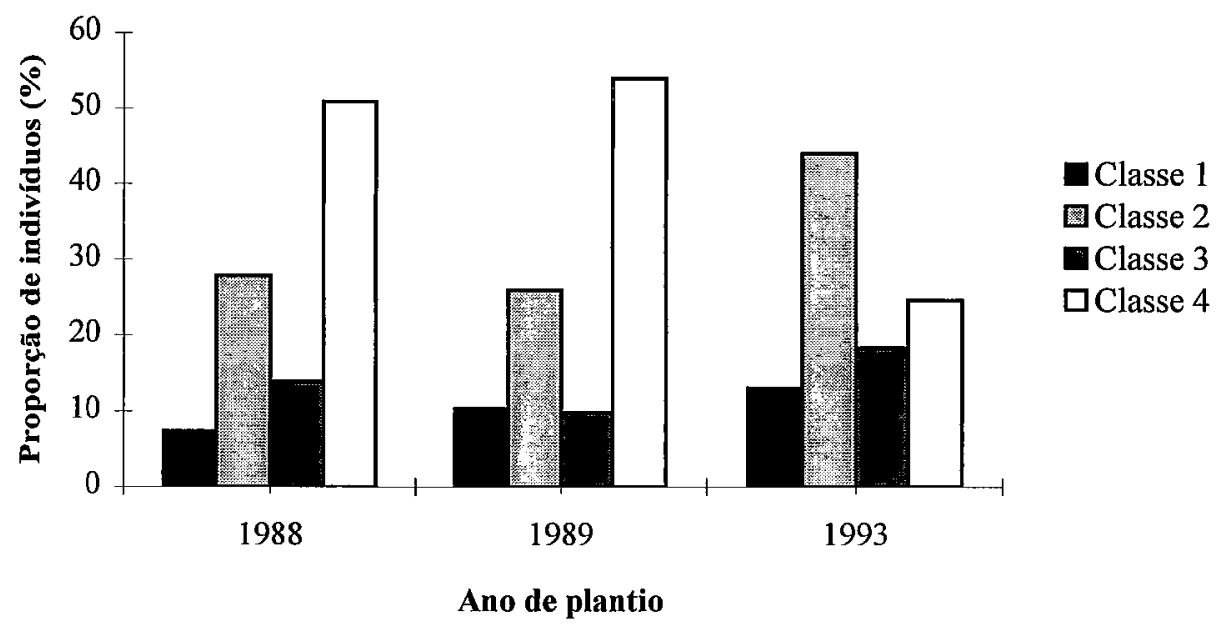

Figura 9. Proporção dos indivíduos de acordo com a classe de copa. Classes de copa: classe 1 - copa emergente; classe 2 - copa de dossel; classe 3 - copa de sub-dossel; classe 4 - copa de sub-bosque.

\subsubsection{Densidade de copa e plantas herbáceas}

Apesar da idade dos reflorestamentos e do relativo fechamento do dossel, ainda verifica-se a presença de espécies herbáceas (predominantemente capim colonião Panicum maximum L.) na maioria das parcelas (Tabela 8).

Esta presença deve estar diretamente relacionada com o histórico de uso da terra, já que as áreas restauradas eram ocupadas com pastagem antes de se iniciarem as atividades de revegetação. Desta forma, acredita-se que o capim colonião encontrado nas parcelas seja ainda remanescente das áreas de pasto, persistindo por condições favoráveis à sua permanência, mesmo com uma estrutura florestal formada.

Dada esta condição (a pré-existência do capim nas áreas), os tratos culturais realizados na implantação dos reflorestamentos e nos anos subseqüentes (capinas manuais e mecanizadas, em média durante três anos) não foram suficientes para impedir a permanência de tais plantas nas áreas restauradas. 
Tabela 8. Valores de densidade de copa, cobertura de espécies herbáceas e decréscimo na densidade de copa para cada parcela.

\begin{tabular}{cccccc}
\hline $\begin{array}{c}\text { Ano de } \\
\text { plantio }\end{array}$ & Parcela & $\begin{array}{c}\text { Dens. copa (\%) } \\
\text { Janeiro 1999 }\end{array}$ & $\begin{array}{c}\text { Dens. copa (\%) } \\
\text { Julho 1999 }\end{array}$ & $\begin{array}{c}\text { Decréscimo na } \\
\text { densidade de copa (\%) }\end{array}$ & $\begin{array}{c}\text { Dens. herbáceas (\%) } \\
\text { Julho 1999 }\end{array}$ \\
\hline \multirow{2}{*}{1988} & 02 & 89,19 & 77,59 & 11,60 & 51,75 \\
& 03 & 99,09 & 97,39 & 1,7 & 6,08 \\
& 06 & 99,09 & 96,55 & 2,54 & 6,90 \\
& 07 & 96,49 & 87,83 & 8,66 & 13,04 \\
\hline \multirow{2}{*}{1989} & 04 & 96,43 & 93,04 & 3,39 & 0,87 \\
& 05 & 99,11 & 95,69 & 3,42 & 10,34 \\
\hline \multirow{2}{*}{1993} & 08 & 100 & 87,72 & 12,28 & 48,25 \\
& 09 & 100 & 91,23 & 8,77 & 14,04 \\
\hline
\end{tabular}

A partir dos dados de densidade de copa apresentados na tabela 8 não é possível perceber nenhuma relação explícita entre a densidade de copa e a ocupação por espécies herbáceas. No entanto, ao verificar-se as diferenças entre os valores de densidade de copa registrados na estação seca e chuvosa, que por sua vez correspondem à entrada de luz proporcionada pela queda das folhas na estação seca, observa-se a existência de uma relação entre tais valores e a densidade de plantas herbáceas, melhor observada na figura 10.

Assim, nota-se que quanto maior a deciduidade, maior a densidade de espécies herbáceas. Isto sugere que, apesar da pouca disponibilidade de água, a luminosidade proporcionada pela queda das folhas de alguns indivíduos, mesmo nas parcelas de idade mais avançada, é suficiente para assegurar a persistência das espécies herbáceas. Parrota \& Knowles (1999) também sugerem uma relação do estabelecimento das gramíneas com a abertura no dossel e conseqüente entrada de luz. Trata-se de um registro importante, tendo em vista que a ocupação de plantas herbáceas pode dificultar o estabelecimento da regeneração natural e comprometer assim, a perpetuação das florestas. 


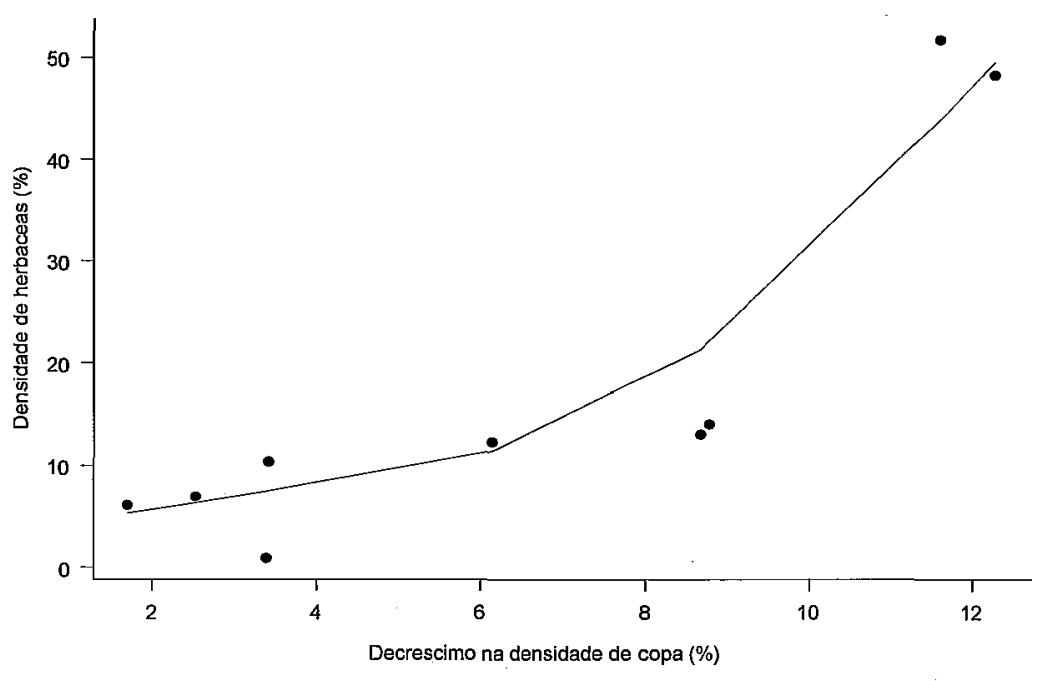

Figura 10. Relação entre o decréscimo na densidade de copa e a densidade de plantas herbáceas.

\subsubsection{Dinâmica}

A partir dos resultados apresentados na tabela 9 observa-se que a área plantada em 1993 foi a que apresentou as maiores taxas de crescimento, tanto em área basal quanto em altura.

Tabela 9. Crescimento relativo, mortalidade e ingresso dos indivíduos com CAP $\geq 15$ $\mathrm{cm}$ registrados no intervalo de 1 ano.

\begin{tabular}{lccc}
\hline Ano de plantio & 1988 & 1989 & 1993 \\
\hline Crescimento em área basal (\%) & 7,3 & 7,2 & 12 \\
Crescimento em altura (\%) & 5,3 & 2,9 & 7,5 \\
Mortalidade (\%) & 1,8 & 1,4 & 1,8 \\
Recrutamento (\%) & 2,0 & 3,2 & 2,4 \\
\hline
\end{tabular}


No que diz respeito à mortalidade, os valores encontrados parecem estar dentro dos padrões observados para florestas tropicais. Em estudos comparando diversos levantamentos de árvores com DAP maior ou igual a $10 \mathrm{~cm}$ em diferentes áreas nos trópicos, Swaine et al. (1987) encontraram taxas de mortalidade variando de 1 a $2 \%$ ao ano. Philips \& Gentry (1994), num estudo semelhante, encontraram taxas variando de 0,67 a 3,27 \% em levantamentos utilizando esse mesmo critério de inclusão.

As taxas de mortalidade nas três áreas são decorrentes principalmente da morte de plantas pioneiras (Figura 11). Este fato confirma as expectativas de que a diversidade das florestas estaria mudando de acordo com os grupos ecológicos. As áreas são ainda jovens, sendo esperada prioritariamente a mortalidade de plantas do início da sucessão secundária, como as pioneiras e as secundárias iniciais.

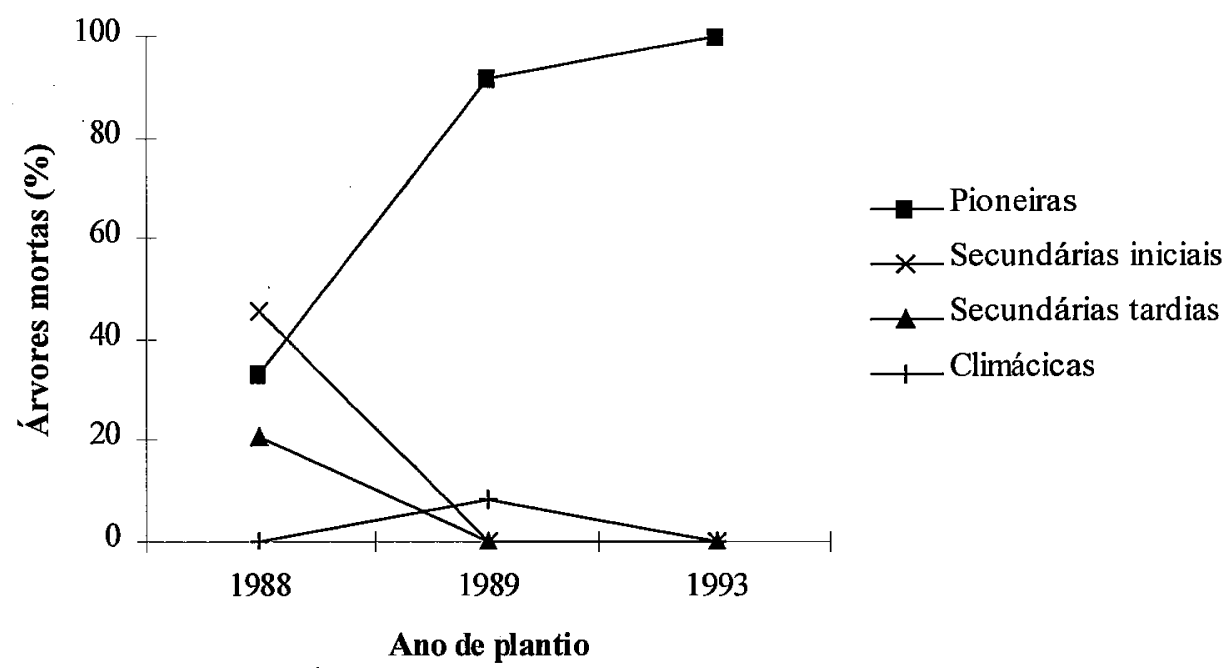

Figura 11. Proporção de árvores mortas (indivíduos com $\mathrm{CAP} \geq 15 \mathrm{~cm}$ ) no intervalo de um ano, segundo os grupos ecológicos.

Segundo Swaine et al. (1987), na maioria dos trabalhos analisados, as taxas de recrutamento são bastante semelhantes às taxas de mortalidade. Sendo assim, os valores encontrados neste trabalho parecem ser razoáveis. A partir de tais valores, nota-se também o crescimento mais rápido dos indivíduos com $\mathrm{CAP}<15 \mathrm{~cm}$ (aqueles que serão 
recrutados) presentes na área plantada em 1989, já que a taxa de recrutamento nesta área é a maior quando comparada às demais.

A figura 12 mostra que o recrutamento segue os rumos da sucessão secundária, com mais indivíduos de espécies secundárias iniciais sendo recrutados, seguidos das secundárias tardias e das climácicas.

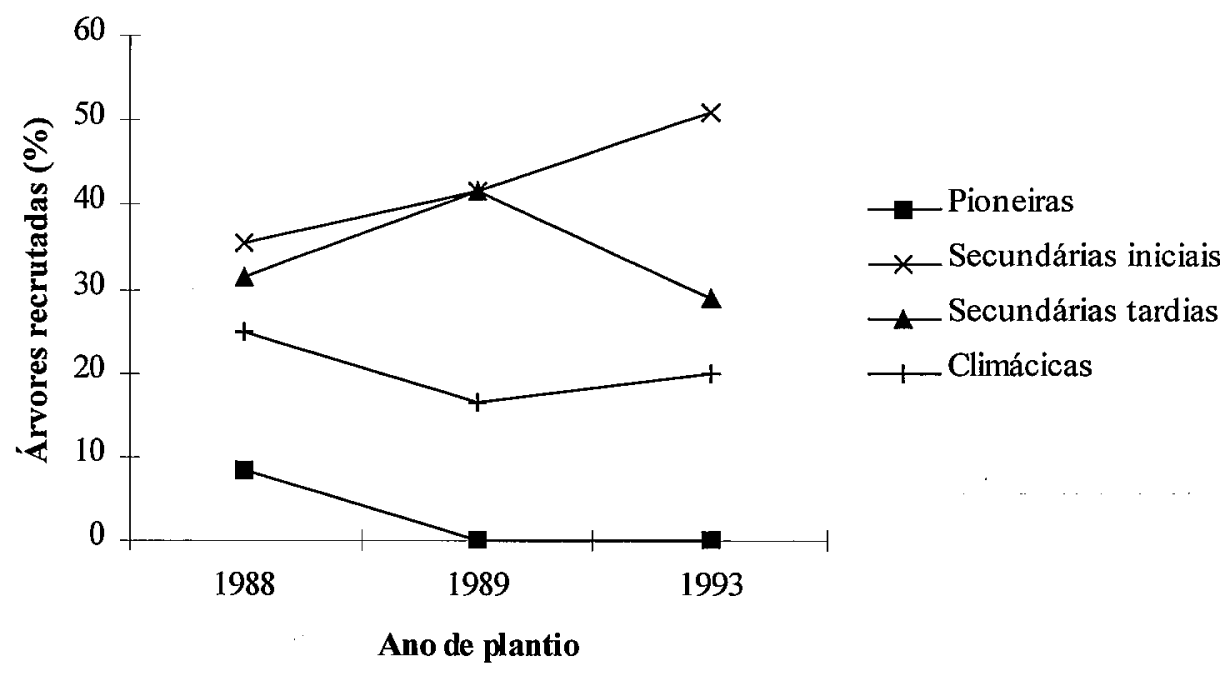

Figura 12. Proporção de árvores recrutadas no intervalo de um ano, segundo os grupos ecológicos.

\subsection{Regeneração natural}

\subsubsection{Composição florística}

A família predominante entre os indivíduos em regeneração da área plantada em 1988 foi Fabaceae, com três espécies. Na área plantada em 1989, cada família teve apenas uma espécie e na área plantada em 1993, nenhum indivíduo lenhoso com altura maior ou igual a $50 \mathrm{~cm}$ e CAP menor que $15 \mathrm{~cm}$ foi amostrado no primeiro levantamento. 
A tabela 10 apresenta os dados gerais da composição florística da regeneração natural das áreas restauradas, de acordo com a idade de plantio. A lista das espécies amostradas com seus respectivos grupos ecológicos e formas de vida encontra-se no anexo B.

Tabela 10. Aspectos gerais da composição florística da regeneração natural (indivíduos lenhosos com altura igual ou superior a $50 \mathrm{~cm}$ e CAP abaixo de $15 \mathrm{~cm}$ ) das áreas reflorestadas, para cada idade de plantio.

\begin{tabular}{lccc}
\hline & \multicolumn{3}{c}{ Ano de plantio } \\
\cline { 2 - 4 } & 1988 & 1989 & 1993 \\
\hline Total de indivíduos amostrados & 49 & 13 & 0 \\
Número de espécies & 16 & 10 & 0 \\
Número de gêneros & 16 & 10 & 0 \\
Número de famílias & 13 & 10 & 0 \\
\hline
\end{tabular}

As espécies predominantes na área plantada em 1988 foram Lonchocarpus muehlbergianus Hassl., com 36,7 \% de densidade relativa, Randia armata (Sw.) DC., com 14,3\% de densidade relativa e Acrocomia aculeata e Croton floribundus, com 8,2 $\%$ de densidade relativa cada uma. Já na área plantada m 1989, cuja riqueza da regeneração natural foi menor, predominaram Lonchocarpus muehlbergianus, Croton floribundus e Xylopia aromatica (Lam.) Mart., com 15,4 \% de densidade relativa cada.

A ausência de indivíduos em regeneração com altura igual ou superior a $50 \mathrm{~cm}$ na área mais jovem (1993) deve-se provavelmente à pouca idade do reflorestamento na época do levantamento (cinco anos e meio). Além disso, o tamanho estabelecido como mínimo para a inclusão dos indivíduos restringe as espécies com potencial de crescimento suficiente para atingir este tamanho com tão pouca idade.

Das 27 espécies arbóreas amostradas (Anexo B), apenas uma (Bastardiopsis densiflora (Hook et Arn.) Hassl.) parece ter vindo de outros remanescentes florestais ou do banco de sementes do solo. Todas as demais espécies possuem representantes de 
indivíduos adultos dentro da própria parcela ou fazem parte da lista de espécies plantadas da CESP, devendo estar presentes em áreas adjacentes.

Além de árvores e arbustos, o recrutamento de outras formas de vida, como lianas e herbáceas, é essencial para a criação de uma estrutura semelhante à encontrada nas florestas tropicais (Tucker \& Murphy 1997). Levando isso em consideração, a distribuição dos indivíduos amostrados (incluindo o primeiro e o segundo levantamentos) de acordo com as formas de vida (Tabela 11) sugere que a área de 1988 é a que apresenta estrutura mais semelhante à da floresta natural, já que nela foram amostrados mais espécies arbustivas e lianas.

Tabela 11. Número de indivíduos da regeneração natural amostrados em dois levantamentos, de acordo com as formas de vida.

\begin{tabular}{ccccc}
\hline \multirow{2}{*}{ Ano de plantio } & \multicolumn{4}{c}{ Formas de vida } \\
\cline { 2 - 5 } & Arvores & Arbustos & Lianas & Indefinida \\
\hline 1988 & 17 & 3 & 6 & 1 \\
1989 & 14 & 2 & 0 & 0 \\
1993 & 3 & 0 & 0 & 0 \\
\hline
\end{tabular}

\subsubsection{Estrutura}

A partir dos dados apresentados na tabela 12, nota-se que a densidade da regeneração natural está de acordo com o que se esperava para as diferentes idades de plantio, ou seja, quanto mais antigo o reflorestamento, maior a densidade das plantas se regenerando. A altura média dos indivíduos também apresentou este comportamento, sendo de 1,74 m na área plantada em 1988 e 1,20 m na área plantada em 1989. Estas informações referem-se aos dados coletados no primeiro levantamento da regeneração natural, realizado em fevereiro de 1999.

No entanto, é preciso saber se tais valores são razoáveis em relação ao que se espera para a sustentabilidade da área, isto é, se a densidade de plantas se regenerando 
pode assegurar a perpetuação da floresta sem que haja necessidade de intervenção. Para tal, seria ideal comparar tais valores com os valores observados em florestas naturais próximas à área de estudo ou mesmo em outras áreas reflorestadas com espécies nativas, embora sejam poucos os trabalhos que tratem deste assunto.

Tabela 12. Valores de densidade de regeneração natural para as três áreas de estudo em comparação com outros trabalhos.

\begin{tabular}{|c|c|c|c|c|}
\hline Referência & Local & Tipo de mata & Critério de inclusão & Densidade (ind./ha) \\
\hline $\begin{array}{c}\text { Área } \\
\text { plantada } \\
\text { em } 1988\end{array}$ & $\begin{array}{l}\text { Primavera } \\
\text { (SP) }\end{array}$ & $\begin{array}{l}\text { Reflorestamento } \\
\text { misto } 11 \text { anos }\end{array}$ & $\begin{array}{c}\text { Indivíduos com } \\
\text { altura } \geq 50 \mathrm{~cm} \mathrm{e} \\
\mathrm{CAP}<15 \mathrm{~cm}\end{array}$ & 6.499 \\
\hline $\begin{array}{c}\text { Área } \\
\text { plantada } \\
\text { em } 1989\end{array}$ & $\begin{array}{l}\text { Primavera } \\
\text { (SP) }\end{array}$ & $\begin{array}{l}\text { Reflorestamento } \\
\text { misto } 10 \text { anos }\end{array}$ & $\begin{array}{c}\text { Indivíduos com } \\
\text { altura } \geq 50 \mathrm{~cm} \text { e } \\
\mathrm{CAP}<15 \mathrm{~cm}\end{array}$ & 3.448 \\
\hline $\begin{array}{c}\text { Área } \\
\text { plantada } \\
\text { em } 1993\end{array}$ & $\begin{array}{l}\text { Itaguajé } \\
(\mathrm{PR})\end{array}$ & $\begin{array}{l}\text { Reflorestamento } \\
\text { misto 5,5 anos }\end{array}$ & $\begin{array}{c}\text { Indivíduos com } \\
\text { altura } \geq 50 \mathrm{~cm} \mathrm{e} \\
\mathrm{CAP}<15 \mathrm{~cm}\end{array}$ & 0 \\
\hline $\begin{array}{l}\text { Durigan \& } \\
\text { Dias (1990) }\end{array}$ & $\begin{array}{c}\text { Cândido Mota } \\
\text { (SP) }\end{array}$ & $\begin{array}{c}\text { Reflorest. misto } \\
\text { Mata ciliar } 17 \text { anos }\end{array}$ & $\begin{array}{c}\text { Indivíduos entre } 5 \text { e } \\
200 \mathrm{~cm} \text { de altura }\end{array}$ & 140.650 \\
\hline $\begin{array}{l}\text { Soares et } \\
\text { al. (1994) }\end{array}$ & $\begin{array}{l}\text { Lavras } \\
\text { (MG) }\end{array}$ & Floresta natural & $\begin{array}{c}\text { Indivíduos com } \\
\mathrm{DAP}<5 \mathrm{~cm}\end{array}$ & $\begin{array}{l}168.100^{(1)} \\
208.000\end{array}$ \\
\hline $\begin{array}{l}\text { Parrota et } \\
\text { al. (1997a) }\end{array}$ & $\begin{array}{l}\text { Porto Trombetas } \\
\text { (PA) }\end{array}$ & $\begin{array}{l}\text { Reflorest. misto } \\
10 \text { anos }\end{array}$ & $\begin{array}{c}\text { Indivíduos com } \\
\text { altura }<2 \mathrm{~m}\end{array}$ & 28.800 \\
\hline $\begin{array}{l}\text { Passos } \\
\text { (1998) }\end{array}$ & $\begin{array}{l}\text { Mogi-Guaçu } \\
\text { (SP) }\end{array}$ & $\begin{array}{c}\text { Floresta natural } \\
\text { (mata ciliar) }\end{array}$ & $\begin{array}{l}\text { Indivíduos com } \\
\text { altura }>10 \mathrm{~cm} \mathrm{e} \\
\text { DAP }<5 \mathrm{~cm}\end{array}$ & $\begin{array}{l}38.500^{(2)} \\
52.500 \\
64.500\end{array}$ \\
\hline $\begin{array}{l}\text { Grombone- } \\
\text { Guaratini } \\
\text { (1999) }\end{array}$ & $\begin{array}{l}\text { Campinas } \\
\text { (SP) }\end{array}$ & Floresta natural & $\begin{array}{c}\text { Indivíduos com } \\
\text { altura } \geq 50 \mathrm{~cm} \mathrm{e}<4 \\
\text { m e PAP }<15 \mathrm{~cm}\end{array}$ & 27.568 \\
\hline
\end{tabular}


Alguns trabalhos que avaliam aspectos da estrutura e dinâmica da regeneração natural são os de Durigan \& Dias (1990), Soares et al. (1994), Parrota et al. (1997a), Passos (1998) e Grombone-Guaratini (1999). No entanto, todos estes trabalhos foram desenvolvidos em diferentes formações florestais e utilizaram diferentes critérios de inclusão para a amostragem da regeneração natural, o que faz com que a comparação seja feita com as devidas ressalvas, como uma forma de auxiliar a interpretação dos valores observados.

Comparando-se os valores apresentados na tabela 12 observa-se uma grande diferença entre as densidades encontradas neste trabalho e as demais. Apesar das considerações feitas sobre os diferentes critérios de inclusão, tipos de floresta e idades de plantio, os valores apresentados no presente trabalho para as áreas reflorestadas parecem ser baixos.

Os trabalhos cujas características mais se aproximam do presente estudo são os de Durigan \& Dias (1990), Passos (1998) e Grombone-Guaratini (1999). O primeiro, por ser um reflorestamento misto no Estado de São Paulo; o segundo e o terceiro, por apresentarem critérios de inclusão mais próximos ao utilizado neste trabalho, servindo como uma possível referência dos valores em áreas naturais.

Durigan \& Dias (1990) comentam que a densidade encontrada em seu levantamento é alta (140.650 indivíduos/ha), o que pode ser notado ao se comparar este valor com os encontrados por Passos (1998) e Grombone-Guaratini (1999). De qualquer forma, tanto a densidade encontrada por Durigan \& Dias (1990) quanto as encontradas por Passos (1998) e Grombone-Guaratini (1999) são bastante superiores aos valores observados no presente trabalho.

Em parte, a baixa densidade de regeneração pode ser explicada pela pouca idade dos reflorestamentos. Parte das plantas ainda não atingiu sua maturidade reprodutiva (Machado ${ }^{1}$ ), deixando, assim, de contribuir com a chuva de sementes. Isto se aplica principalmente ao caso da área plantada em 1993, já que a área era ainda bastante jovem na época do levantamento (cinco anos e meio).

\footnotetext{
${ }^{1}$ Celso Machado. (Companhia Energética do Estado de São Paulo - CESP). Comunicação pessoal, 2000.
} 
Dentre os diversos fatores que podem ser responsáveis pela determinação dos padrões da regeneração natural numa área, o histórico do uso da terra, o banco de sementes (Guariguata et al. 1995), a distância de fontes colonizadoras (McClanahan 1986, Robinson \& Handel 1993, Parrota et al. 1997a e b) e a dispersão de propágulos (McDonnel \& Stiles 1983, McClanahan 1986, Bakker et al. 1996, McClanahan \& Wolfe 1993, Robinson \& Handel 1993) parecem ser os principais neste caso.

Antes da construção das usinas hidroelétricas, as áreas já haviam sido transformadas em pastagens, o que certamente comprometeu a composição do banco de sementes do solo.

No que se refere à distância de fontes colonizadoras, a situação torna-se ainda mais delicada. Isto porque as áreas reflorestadas nos anos de 1988 e 1989 encontram-se praticamente isoladas de outros remanescentes florestais. A fonte de propágulos e de animais dispersores mais próxima é a Estação Ecológica dos Caiuás, uma reserva de cerca de 1.426 ha, situada na outra margem do reservatório, sendo que as áreas reflorestadas e a Estação ficam separadas por aproximadamente $3 \mathrm{~km}$ de água. Considerando que a maioria das espécies tropicais é dispersa por animais (Tucker \& Murphy 1997), a presença da água entre as áreas restauradas e a floresta natural reduz drasticamente a chegada de propágulos.

No caso da área plantada em 1993, a situação é semelhante, predominando áreas de pasto no seu entorno. Levando-se em consideração que a abundância e a diversidade de espécies colonizadoras decresce com a distância da fonte de propágulos (Van Ruremonde \& Kalkhoven 1991, Parrota et al. 1997a) e que a dispersão das sementes e a colonização por novas espécies são alguns dos fatores responsáveis pela restauração da biodiversidade (Wunderle Jr. 1997), este isolamento poderá comprometer a diversidade das áreas restauradas a longo prazo.

Além disso, o modelo de plantio, conforme sugerido por Parrota (1993 e 1995) e por Wunderle Jr. (1997), também pode estar exercendo alguma influência no estabelecimento da regeneração destas áreas. A composição florística de cada plantio influencia diretamente a atratividade à fauna, e conseqüentemente o processo de dispersão e colonização das áreas. Esta composição também pode interferir no 
microclima do sub-bosque, propiciando maior ou menor entrada de luz devido à deciduidade de algumas espécies, e na quantidade de serapilheira produzida, que por sua vez pode influenciar o sucesso do estabelecimento das plântulas.

São poucos os estudos sobre o efeito da composição de espécies na composição do sub-bosque em áreas tropicais (Guariguata et al. 1995), limitando o conhecimento sobre tais relações.

A competição com gramíneas invasoras (Parrota 1993, Holl \& Kappelle 1999) é outro fator que pode ter relação com o sucesso da regeneração. De maneira geral, todas as áreas apresentam ainda uma grande presença de capim colonião, apesar da idade dos plantios e do fechamento do dossel (Tabela 8), o que pode estar limitando o estabelecimento dos indivíduos.

\subsubsection{Dinâmica}

Analisando os aspectos da dinâmica da regeneração natural, verifica-se que embora a densidade de plantas se regenerando tenha aumentado em todas as áreas no período de um ano, este aumento foi bastante diferente entre elas (Tabela 13).

Tabela 13. Densidade, número de espécies e altura média dos indivíduos em regeneração (altura $\geq 50 \mathrm{~cm}$ e CAP $<15 \mathrm{~cm}$ ) registrados no intervalo de um ano. $\mathbf{L 1}$ Primeiro levantamento (março/1999); L2 - Segundo levantamento (fevereiro/2000).

\begin{tabular}{ccccccc}
\hline & \multicolumn{2}{c}{$\begin{array}{c}\text { Densidade } \\
\text { (indivíduos/ha) }\end{array}$} & \multicolumn{2}{c}{ Número de espécies } & \multicolumn{2}{c}{ Altura média (m) } \\
\hline Ano de plantio & L1 & L2 & L1 & L2 & L1 & L2 \\
\hline 1988 & 6.499 & 6.631 & 16 & 18 & 1,74 & 1,57 \\
1989 & 3.448 & 4.244 & 10 & 10 & 1,20 & 1,10 \\
1993 & 0 & 707 & 0 & 3 & - & 0,86 \\
\hline
\end{tabular}


$\mathrm{Na}$ área plantada em 1988, o aumento na densidade foi de apenas $2 \%$, enquanto que na área de 1989 o aumento foi de cerca de $23 \%$. Para a área plantada em 1993, o estudo da dinâmica trouxe um dado importante. No primeiro levantamento, nenhum indivíduo lenhoso com altura igual ou superior a $50 \mathrm{~cm}$ e CAP abaixo de $15 \mathrm{~cm}$ havia sido amostrado, enquanto que no segundo levantamento já puderam ser observados alguns indivíduos em regeneração.

Este fato torna-se particularmente importante se for levada em consideração a predominância de espécies pioneiras (Tabela 6) naquela área. Sabendo que tais espécies apresentam baixa longevidade, espera-se que a partir dos próximos anos muitos indivíduos comecem a morrer, abrindo grandes clareiras dentro da mata. Se por um lado a abertura de clareiras pode facilitar o processo de sucessão através da maior entrada de luz (Schupp et al. 1989), as mudanças drásticas no microclima conseqüentes da abertura no dossel podem provocar a morte da grande maioria das plantas jovens presentes no sub-bosque (Whitmore 1978).

Com isto e sem um sub-bosque alto, denso e rico em espécies, a floresta pode ser dominada por gramíneas invasoras e espécies pioneiras de ciclo de vida muito curto (Parrota \& Knowles 1999), comprometendo a sustentabilidade da floresta. 


\section{CONCLUSÕES}

O estabelecimento da cobertura vegetal nas três áreas estudadas parece estar criando condições para a formação de florestas com estruturas semelhantes às de uma floresta natural. No entanto, em virtude da complexidade e da longa escala de tempo na qual ocorrem os processos ecológicos nas regiões tropicais, as afirmações sobre a sustentabilidade dessas florestas só poderão ser feitas mediante o monitoramento das áreas restauradas.

A partir dos resultados obtidos no presente trabalho pôde-se fazer, além da caracterização das áreas restauradas, algumas inferências sobre as técnicas utilizadas e suas implicações para o desenvolvimento da floresta:

- A riqueza, diversidade e equabilidade das áreas plantadas foram mais baixas nas áreas plantadas em 1989 e 1993 . Nestas áreas, a alta concentração dos indivíduos em apenas duas espécies (correspondendo a mais de $50 \%$ de densidade relativa) foi responsável pelos baixos valores observados;

- A proporção de indivíduos de acordo com os grupos ecológicos exerceu influência direta no desenvolvimento da estrutura da floresta, determinando também aspectos importantes da dinâmica como o ritmo de crescimento e as taxas de mortalidade;

- A disponibilidade de luz na estação seca, proporcionada pela queda das folhas de algumas espécies, parece contribuir para a persistência de plantas herbáceas nas áreas estudadas; 
- No que se refere à dinâmica, os valores de mortalidade e recrutamento estão seguindo os rumos da sucessão secundária, de maneira semelhante à floresta natural;

- A baixa densidade de plantas em regeneração pode ser explicada pela pouca idade das áreas estudadas e pelas limitações de alguns mecanismos de regeneração natural nestas áreas, como a chegada de propágulos de outras fontes e o banco de sementes;

- Considerando-se a riqueza, a diversidade, a equabilidade, a densidade de indivíduos em regeneração e o recrutamento de outras formas de vida, além de espécies arbóreas, a área plantada em 1988 (sem os princípios de sucessão secundária), foi a que mais se assemelhou à floresta natural. 


\section{IMPLICAÇÕES PARA A RESTAURAÇÃo}

A proporção dos grupos ecológicos na composição de espécies no plantio deve ser cuidadosamente planejada a fim de propiciar um desenvolvimento adequado da floresta. Atenção especial deve ser dada às espécies iniciais de sucessão, principalmente do grupo das pioneiras. Embora estas espécies permitam o rápido recobrimento do solo e o fechamento do dossel, que são fatores desejáveis para a formação de uma estrutura florestal, seu ciclo de vida curto e sua conseqüente mortalidade podem interferir negativamente no estabelecimento da floresta se um sub-bosque denso e rico em espécies ainda não estiver formado e pronto para ocupar o estrato superior.

Além do grupo ecológico a que pertencem, outras características das espécies também devem ser consideradas. A atratividade à fauna pode contribuir muito com o intercâmbio de sementes e, conseqüentemente, com o aumento da diversidade da floresta através da chegada de novas espécies.

A situação da área a ser restaurada em relação à paisagem pode ser um fator primordial no sucesso de um projeto de restauração. Para Wunderle Jr. (1997), o ideal é que a área a ser restaurada seja contígua a remanescentes de floresta nativa, o que é condição rara em virtude da intensa fragmentação das florestas encontradas no estado. Neste caso, este autor recomenda a criação de corredores de vegetação entre as áreas restauradas e os fragmentos mais próximos, a fim de possibilitar o deslocamento de animais dispersores e favorecer o fluxo de sementes.

Nas situações onde nem isto for possível, as estratégias de restauração devem ser repensadas. Técnicas auxiliares como o enriquecimento com espécies secundárias tardias e climácicas podem ser necessárias em uma segunda fase, o que pode inviabilizar a realização do projeto por causa dos custos. 
Uma alternativa mais viável é a utilização de um grande número de espécies no plantio. Com uma alta riqueza, a chegada de propágulos de outras fontes não se torna tão necessária na manutenção da diversidade da floresta.

Quanto à persistência de plantas herbáceas em áreas que apresentam histórico de ocupação destas espécies, uma alternativa é a aplicação de herbicidas pré-emergentes no plantio. Isto só deve ser feito em locais onde o banco de sementes do solo já esteja comprometido pelo histórico do uso da terra ou pelo grau de degradação da área, não sendo mais uma fonte potencial de propágulos para a regeneração da floresta. 


\section{REFERÊNCIAS BIBLIOGRÁFICAS}

ABER, J.D. Restored forests and the identification of critical factors in species-site interactions. In: JORDAN III, W.R.; GILPIN, M.E.; ABER, J.D. (Ed.) Restoration ecology - A synthetic approach to ecological research. Cambridge: University Press, 1987. p.241-250.

ALLEN, J.A. Reforestation of bottomland hardwoods and the issue of woody species diversity. Restoration Ecology, v.5, n.2, p.125-134, 1997.

ANDERSEN, A.N.; MORRISON, S.C. Myrmecochory in Australia's seasonal tropics: effects of disturbance on distance dispersal. Australian Journal of Ecology, v.23, p.483-491, 1998.

ANDERSEN, A.N.; SPARLING, G.P. Ants as indicators of restoration success: relationship with soil microbial biomass in the australian seasonal tropics. Restoration Ecology, v.5, n.2, p.109-114, 1997.

ARONSON, J.; LE FLOC'H, E. Vital landscape attributes: missing tools for restoration ecology. Restoration Ecology, v.4, n.4, p.377-387, 1996.

ASHBY, W.C. Forests. In: JORDAN III, W.R.; GILPIN, M.E.; ABER, J.D. (Ed.) Restoration ecology - A synthetic approach to ecological research. Cambridge: University Press, 1987. p.89-108.

BAKKER, J.P.; BERENDESE, F. Constraints in the restoration of ecological diversity in grassland and heatland communities. Trends in ecology and evolution, v.14, n.2, p.63-68, 1999.

BAKKER, J.P.; POSCHLOD, P.; STRYKSTRA, R.J.; BEKKER, R.M.; THOMPSON, K. Seed banks and seed dispersal: important topics in restoration ecology. Acta 
Botanica Neerlandica, v.45, n.4, p.461-490, 1996.

BAWA, K.S.; SEIDLER, R. Natural forest management and conservation of biodiversity in tropical forests. Conservation Biology, v.12, n.1, p.46-55, 1998.

BELL, S.S.; FONSECA, M.S.; MOTTEN L. B. Linking restoration and landscape ecology. Restoration Ecology, v.5, n.4, p.318-323, 1997.

BENTHAM, H.; HARRIS, J.A.; BIRCH, P.; SHORT, K.C. Habitat classification and soil restoration assessment using analysis of soil microbiological and physicochemical characteristics. Journal of Applied Ecology, v.29, p.711-718, 1992.

BOX, J. Setting objectives and defining outputs for ecological restoration and habitat creation. Restoration Ecology, v.4, n.4, p.427-432, 1996.

BRADSHAW, A.D. Restoration: an acid test for ecology. In: JORDAN III, W.R.; GILPIN, M.E.; ABER, J.D. (Ed.) Restoration ecology - A synthetic approach to ecological research. Cambridge: University Press, 1987. p.23-29.

BROWN, D. Estimating the composition of a forest seed bank: a comparision of the seed extraction and seedling emergence methods. Canadian Journal of Botany, v.70, p.1603-1612, 1992.

BUDOWSKI, G. Ditribution of a tropical American rain forest species in the light of successional processes. Turrialba, v.15, n.1, p.40-42, 1965.

CARPANEZZI, A. A.; COSTA, L. G. S.; KageYAMA, P. Y.; CASTRO, C. F. A. Espécies pioneiras para recuperação de áreas degradadas: a observação de laboratórios naturais. In:CONGRESSO FLORESTAL BRASILEIRO, 6, Campos do Jordão, 1990. Campos do Jordão: 1990. p.216-221. 
CESP. Recomposição de matas nativas pela CESP. São Paulo: 1992. 13p.

CLEWELL, A.; RIEGER, J.P. What practitioners need from restoration ecologists. Restoration Ecology, v.5, n.4, p.350-354, 1997.

CLEWELL, A.F. Restoration of riverine forest at hall branch on phosphate-mined land, Florida. Restoration Ecology, v.7, n.1, p.1-14, 1999.

CRONQUIST, A. An integrated system of classification of flowering plants. New York: Columbia University Press, 1981. 1262p.

DIEGUES, A.C.S. Inventário de áreas úmidas do Brasil. Versão Preliminar. Programa de Pesquisa e Conservação de Áreas Úmidas no Brasil. São Paulo: USP/UICN/FORD, 1990. 446p.

DURIGAN, G.; DIAS, H. C. S. Abundância e diversidade da regeneração natural sob mata ciliar implantada. In:CONGRESSO FLORESTAL BRASILEIRO, 6, Campos do Jordão, 1990. Campos do Jordão: 1990. p.308-312.

EHRENFELD, J.G.; TOTH, L.A. Restoration ecology and the ecosystem perspective. Restoration Ecology, v.5, n.4, p.307-317, 1997.

FANG, W.; PENG, S.L. Development of species diversity in the restoration process of establishing a tropical man-made forest ecosystem in China. Forest Ecology and Management, v.99, p.185-196, 1997.

FONSECA, R.C.B. Fenologia e estrutura de uma floresta semidecídua em Botucatu SP: relação com as fases de desenvolvimento sucessional. Piracicaba, 1998. 104 p. Dissertação (Mestrado) - ESALQ.

GILPIN, M.E. Experimental community assembly: competition, community structure 
and the order of species introduction. In: JORDAN III, W.R.; GILPIN, M.E.; ABER, J.D. (Ed.) Restoration ecology - A synthetic approach to ecological research. Cambridge: University Press, 1987. p.151-161.

GOVERNO do ESTAdo DE SÃo PAULO Atlas regional do Estado de São Paulo Presidente Prudente. São Paulo: 1978.

GROMBONE-GUARATINI, M.T. Dinâmica de uma Floresta Estacional Semidecidual: o banco, a chuva de sementes e o estrato de regeneração. Campinas, 1999.150 p. Tese (Doutorado) - UNICAMP.

GROSS, K.L. Mechanisms of colonization and species persistence in plant communities. In: JORDAN III, W.R.; GILPIN, M.E.; ABER, J.D. (Ed.) Restoration ecology - A synthetic approach to ecological research. Cambridge: University Press, 1987. p.173-188.

GUARIGUATA, M.R.; RHEINGANS, R.; MONTAGNINI, F. Early woody invasion under tree plantations in Costa Rica: implications for forest restoration. Restoration Ecology, v.3, n.4, p.252-260, 1995.

GUEVARA, S.; PURATA, S.E.; VAN DER MAAREL, E. The role of remnant forest trees in tropical secondary succession. Vegetatio, v.66, p.77-84, 1986.

HAGGAR, J.; WIGHTMAN, K.; FISHER, R. The potential of plantations to foster woody regeneration within a deforested ladscape in lowland Costa Rica. Forest Ecology and Management, v.99, p.55-94, 1997.

HARPER, J.L. The heuristic value of ecological restoration. In: JORDAN III, W.R.; GILPIN, M.E.; ABER, J.D. (Ed.) Restoration ecology - A synthetic approach to ecological research. Cambridge: University Press, 1987. p.35-45. 
HARTSHORN, G.S. Neotropical forest dynamics. Biotropica, v.12 (supl.), p.23-30, 1980.

HIGGS, E.S. What is good ecological restoration? Conservation Biology, v.11, n.2, p.338-348, 1997.

HOBBS, R.J.; NORTON, D.A. Towards a conceptual framework for restoration ecology. Restoration Ecology, v.4, n.2, p.93-110, 1996.

HOLL, K.D.; KAPPELLE, M. Tropical forest recovery and restoration. Trends in ecology and evolution, v.14, n.10, p.378-379, 1999.

HOLL, K.D.; LULOW, M.E. Effects of species, habitat, and distance from edge on post-dispersal seed predation in a tropical rainforest. Biotropica, v.29, n.4, p.459$468,1997$.

ITESP Pontal Verde: Plano de recuperação ambiental nos assentamentos do Pontal do Paranapanema. São Paulo: ITESP, 1998a. 65p.

ITESP Terra e cidadãos: aspectos da ação de regularização fundiária no Estado de São Paulo. São Paulo: ITESP, 1998b. 128p.

JACKSON, L.; LOPOUKHINE, N.; HILLYARD, D. Ecological restoration: a definition and comments. Restoration Ecology, v.3, n.2, p.71-75, 1995.

JANSEN, A. Terrestrial invertebrate community structure as an indicator of the success of a tropical rainforest restoration project. Restoration Ecology, v.5, n.2, p.115124, 1997.

JORDAN III, W.R.; GILPIN, M.E.; ABER, J.D. Restoration ecology: ecological restoration as a technique for basic research. In: JORDAN III, W.R.; GILPIN, 
M.E.; ABER, J.D. (Ed.) Restoration ecology - A synthetic approach to ecological research. Cambridge: University Press, 1987. p.3-21.

JORDAN III, W.R.; PETERS II, R.L.; ALLEN, E.B. Ecological restoration as a strategy for conserving biological diversity. Environmental Management, v.12, n.1, p.55-72, 1988.

KAGEYAMA, P.Y.; GANDARA, F.B. Revegetação de áreas ciliares. In: RODRIGUES, R.R.; LEITÃO-FILHO, H.F. (Ed.) Matas ciliares: estado atual do conhecimento. (no prelo).

KAGEYAMA, P. Y.; SANTARELLI, E.; GANDARA, F. B.; GONÇALVES, J. C.; SIMIONATO, J. L.; ANTIQUEIRA, L. R.; GERES, W. L. Revegetação de áreas degradadas: modelos de consorciação com alta diversidade. In: SIMPÓSIO SULAMERICANO, 1 E SIMPÓSIO NACIONAL, 2 DE RECUPERAÇÃO DE ÁREAS DEGRADADAS, Foz do Iguaçu. Curitiba: FUPEF, 1994. p.569-76.

KELLY, J.R.; HARWELL, M.A. Indicators of ecosystem recovery. Environmental Management, v.14, n.5, p.527-545, 1990.

KONDOLF, G.M. Five elements for effective evaluation of stream restoration. Restoration Ecology, v.3, n.2, p.133-136, 1995.

KOTCHETKOFF-HENRIQUES, O.; JOLY, C.A. Estudo florístico e fitossociológico em uma mata mesófila semidecídua da Serra do Itaqueri, Itirapina, estado de São Paulo, Brasil. Revista Brasileira de Biologia, v.54, n.3, p.477-487, 1994.

LANDRES, P.B.; VERNER, J.; THOMAS, J.W. Ecological uses of vertebrate indicator species: a critique. Conservation Biology, v.2, n.4, p.316-328, 1988.

LARSON, D.W. Brown's woods: an early gravel pit forest restoration project, Ontario, 
Canada. Restoration Ecology, v.4, n.1, p.11-18, 1996.

LESICA, P.; ALLENDORF, F.W. Ecological genetics and the restoration of plant communities: mix or match? Restoration Ecology, v.7, n.1, p.42-50, 1999.

LUGO, A.E. The apparent paradox of reestablishing species richness on degraded lands with tree monocultures. Forest Ecology and Management, v.99, p.9-19, 1997.

MACLEAN, D.; WEIN, R.W. Changes in understory vegetation with increasing stand age in New Brunswick forests: species composition, cover, biomass, and nutrients. Canadian Journal of Botany, v.55, p.2818-2831, 1977.

MAGURRAN, A.E. Ecologycal diversity and its measurement. Cambridge: University Press, 1988 . 185p.

MAJER, J.D.; NICHOLS, O.G. Long-term recolonization patterns of ants in Western Australian rehabilitated bauxite mines with reference to their use as indicators of restoration success. Journal of Applied Ecology, v.35, p.161-182, 1998.

MCCLANAHAN, T.R. The effect of a seed source on primary succession in a forest ecosystem. Vegetatio, v.65, p.175-178, 1986.

MCCLANAHAN, T.R.; WOLFE, R.W. Accelerating forest succession in a fragmented landscape: the role of birds and perches. Conservation Biology, v.7, n.2, p.279288, 1993.

MCDONNELL, M.J.; STILES, E.W. The structural complexity of old field vegetation and the recruitment of bird-dispersed plant species. Oecologia, v.56, p.109-116, 1983.

MICHENER, W.K. Quantitatively evaluating restoration experiments: research design, 
statistical analysis, and data management considerations. Restoration Ecology, v.5, n.4, p.324-337, 1997.

MONTALVO, A.M.; WILLIAMS, S.; RICE, K.J.; BUCHMANN, S.L.; CORY, C.; HANDEL, S.N.; NABHAN, G.P.; PRIMACK, R.; ROBICHAUX, R.H. Restoration biology: a population biology perspective. Restoration Ecology, v.5, n.4, p.277-290, 1997.

NOSS, R.F.; HARRIS, L.D. Nodes, networks, and MUMs: preserving diversity at all scales. Environmental Management, v.10, n.3, p.299-309, 1986.

PALMER, M.A.; AMBROSE, R.F.; POFF, N.L. Ecological theory and community restoration ecology. Restoration Ecology, v.5, n.4, p.291-300, 1997.

PARROTA, J.A. Secondary forest regeneration on degraded tropical lands: the role of plantations as "foster ecosysems". In: LIETH, H.; LOHMANN, M. (Ed.) Restoration of tropical forest ecosystems. Netherlands: Kluwer Academic Publishers, 1993. p.63-73.

PARROTA, J.A. Influence of overstory composition on understory colonization by native species in plantations on a degraded tropical site. Journal of Vegetation Science, v.6, p.627-636, 1995.

PARROTA, J.A.; KNOWLES, O.H. Restoration of tropical moist forests on bauxitemined lands in the Brazilian Amazon. Restoration Ecology, v.7, n.2, p.103-116, 1999.

PARROTA, J.A.; KNOWLES, O.H.; WUNDERLE JR. Development of floristic diversity in 10-year-old restoration forests on a bauxite mined site in Amazonia. Forest Ecology and Management, v.99, p.21-42, 1997a. 
PARROTA, J.A.; TURNBULL, J.W.; JONES, N. Catalyzing native forest regeneration on degraded tropical lands. Forest Ecology and Management, v.99, p.1-7, 1997b.

PASSOS, M.J. Estrutura da vegetação arbórea e regeneração natural em remanescentes de mata ciliar do Rio Mogi Guaçu, SP. Piracicaba, 1998. 68 p. Dissertação (Mestrado) - ESALQ.

PENHA, A.S. Propagação vegetativa de espécies arbóreas a partir de raízes gemíferas: representatividade na estrutura fitossociológica e descrição dos padrões de rebrota de uma comunidade florestal, Campinas, São Paulo. Campinas, 1998. 114 p. Dissertação (Mestrado) - UNICAMP.

PETERKEN, G.F.; GAME, M. Historical factors affecting the number and distribution of vascular plant species in the woodlands of central Lincolnshire. Journal of Ecology, v.72, p.155-182, 1984.

PHILIPS, O.L.; GENTRY, A.H. Increasing turnover trhough time in tropical forests. Science, v.263, p.954-958, 1994.

PHINN, S.R.; STOW, D.A.; ZEDLER, J.B. Monitoring wetland habitat restoration in southern California using airbone multispectral video data. Restoration Ecology, v.4, n.4, p.412-422, 1996.

PIELOU, E.C. Ecological diversity. New York: John Wiley, 1975. 165p.

PINTO, M.M. Levantamento fitossociológico de mata residual situada no campus de Jaboticabal da UNESP. Jaboticabal, 1989. 114 p. $\quad$ Dissertação (Mestrado) UNESP.

ROBINSON, G.R.; HANDEL, S.N. Forest restoration on a closed landfill: rapid addition of new species by bird dispersal. Conservation Biology, v.7, n.2, p.271- 
$278,1993$.

RODRIGUES, R.R. Análise de um remanescente de vegetação natural às margens do Rio Passa Cinco, Ipeúna, SP. Campinas, 1991. 334 p. Tese (Doutorado) UNICAMP.

RODRIGUES, R.R. Colonização e enriquecimento de um fragmento florestal urbano após a ocorrência de fogo, Fazenda Santa Elisa, Campinas, SP: avaliação temporal da regeneração natural (66 meses) e do crescimento (51 meses) de 30 espécies florestais plantadas em consórcios sucessionais. Piracicaba, 1999. 167 p. Tese (Livre Docente) - ESALQ.

RODRIGUES, R.R.; GANDOLFI, S. Restauração de florestas tropicais: subsídios para uma definição metodológica e indicadores de avaliação e monitoramento. In: DIAS, L.E.; MELLO, J.W.V. (Ed.) Recuperação de áreas degradadas. Viçosa: UFV, Departamento de solos, 1998. p.203-215.

ROSENBERG, D.B.; DANKS, H.V.; LEHMKUHL, D.M. Importance of insects in environmental impact assessment. Environmental Management, v.10, n.6, p.773$783,1986$.

ROZZA, A.F. Florística, fitossociologia e caracterização sucessional em uma floresta estacional semidecidual: Mata da Virgínia, Matão, SP. Campinas, 1997. 176 p. Dissertação (Mestrado) - UNICAMP.

SALOMÃO, R. P.; ROSA, N. A.; FERRAZ, J.; MATOS, A. H. Uso de parcelas permanentes em reflorestamentos de diversas idades para avaliação da recuperação de áreas mineradas, Porto Trombetas, Oriximiná, Pará. In:SIMPÓSIO NACIONAL DE RECUPERAÇÃO DE ÁREAS DEGRADADAS - SINRAD, 3, Ouro Preto. Ouro Preto: SOBRADE, 1997. p.407-415. 
SCHLITTLER, F.H.M.; MARINIS, G.; CESAR, O. Estudos fitossociológicos na floresta do Morro do Diabo (Pontal do Paranapanema, SP). Arquivo de Biologia e Tecnologia, v.38, n.1, p.217-234, 1995.

SCHUPP, E.W.; HOWE, H.F.; AUGSPURGER, C.K. Arrival and survival in tropical treefall gaps. Ecology, v.70, n.3, p.562-564, 1989.

SHEAR, T.H.; LENT, T.J.; FRAVER, S. Comparision of restored and mature bottomland hardwood forests of southwestern Kentucky. Restoration Ecology, v.4, n.2, p.111-123, 1996.

SOARES, A.R.; SILVA, G.; DIAS, H.C.T.; GARCIA JUNIOR, I.P. Dinâmica de populações de plantas jovens que ocorrem numa floresta estacional semidecídua montana em Lavras, Minas Gerais. Cerne, v.1, n.1, p.28-37, 1994.

STAMPFLI, A.; ZEITER, M. Plant species decline due to abandonment of meadows cannot easily be reversed by mowing. A case of study from southern Alps. Journal of Vegetation Science, v.10, p.151-164, 1999.

STOHLGREN, T.J. Planning long-term vegetation studies at landscape scales. In: POWELL, T.M.; STEELE, J.H. (Ed.) Ecological Time Series. New York: Chapman \& Hall, 1995. p.209-241.

STRYKSTRA, R.J.; BEKKER, R.M.; BAKKER, J.P. Assessment of dispersule availability: its practical use in restoration management. Acta Botanica Neerlandica, v.47, n.1, p.57-70, 1998.

STUMPF, K. A. The estimation of forest vegetation cover descriptions using a vertical densitometer. In:SAF NATIONAL CONVENTION. Indianapolis: 1993.

SWAINE, M.D.; LIEBERMAN, D.; PUTZ, F.E. The dynamics of tree populations in 
tropical forest: a review. Journal of Tropical Ecology, v.3, p.359-366, 1987.

TUCKER, N.I.J.; MURPHY, T.M. The effects of ecological rehabilitation on vegetation recruitment: some observations from the wet tropics of North Queensland. Forest Ecology and Management, v.99, p.133-152, 1997.

VAN AARDE, R.J.; FERREIRA, S.M.; KRITZINGER, J.J.; VAN DYK, P.J.; VOGT, M.; WASSENAAR, T.D. An evaluation of habitat rehabilitation on coastal dune forests in northern KwaZulu-Natal, South Africa. Restoration Ecology, v.4, n.4, p.334-345, 1996.

VAN RUREMONDE, R.H.A.C.; KALKHOVEN, J.T.R. Effects of woodlot isolation on the dispersion of plants with fleshy fruits. Journal of Vegetation Science, v.10, p.377-384, 1991.

VELOSO, H.P.; RANGEL FILHO, A.L.; LIMA, J.C.A. Classificação da vegetação brasileira, adaptada a um sistema universal. Rio de Janeiro: IBGE, 1991. 124p.

VICTOR, M. A. M. A devastação florestal. São Paulo: Sociedade Brasileira de Silvicultura, $1975.48 \mathrm{p}$.

WALTERS, B.B. Human ecological questions for tropical restoration: experiences from planting native upland trees and mangroves in the Phillipines. Forest Ecology and Management, v.99, p.275-290, 1997.

WHITE, P.S.; WALKER, J.L. Approximating nature's variation: selecting and using reference information in restoration ecology. Restoration Ecology, v.5, n.4, p.338349, 1997.

WHITMORE, T.C. Gaps in the forest canopy. In: TOMLINSON, P. B.; ZIMMERMANN, M. H. (Ed.). Tropical trees as living systems Cambridge: 
Cambridge University Press, 1978. p.639-655.

WILSON, E.O. A situação atual da diversidade biológica. In: WILSON, E.O. (Org.) Biodiversidade. Rio de Janeiro: Editora Nova Fronteira, 1997. p.3-24.

WUNDERLE JR., J.M. The role of animal seed dispersal in accelerating native forest regeneration on degraded tropical lands. Forest Ecology and Management, v.99, p.223-235, 1997.

YOUNG, T.P. Restoration ecology and conservation biology. Biological Conservation, v.92, p.73-83, 2000. 
ANEXOS 


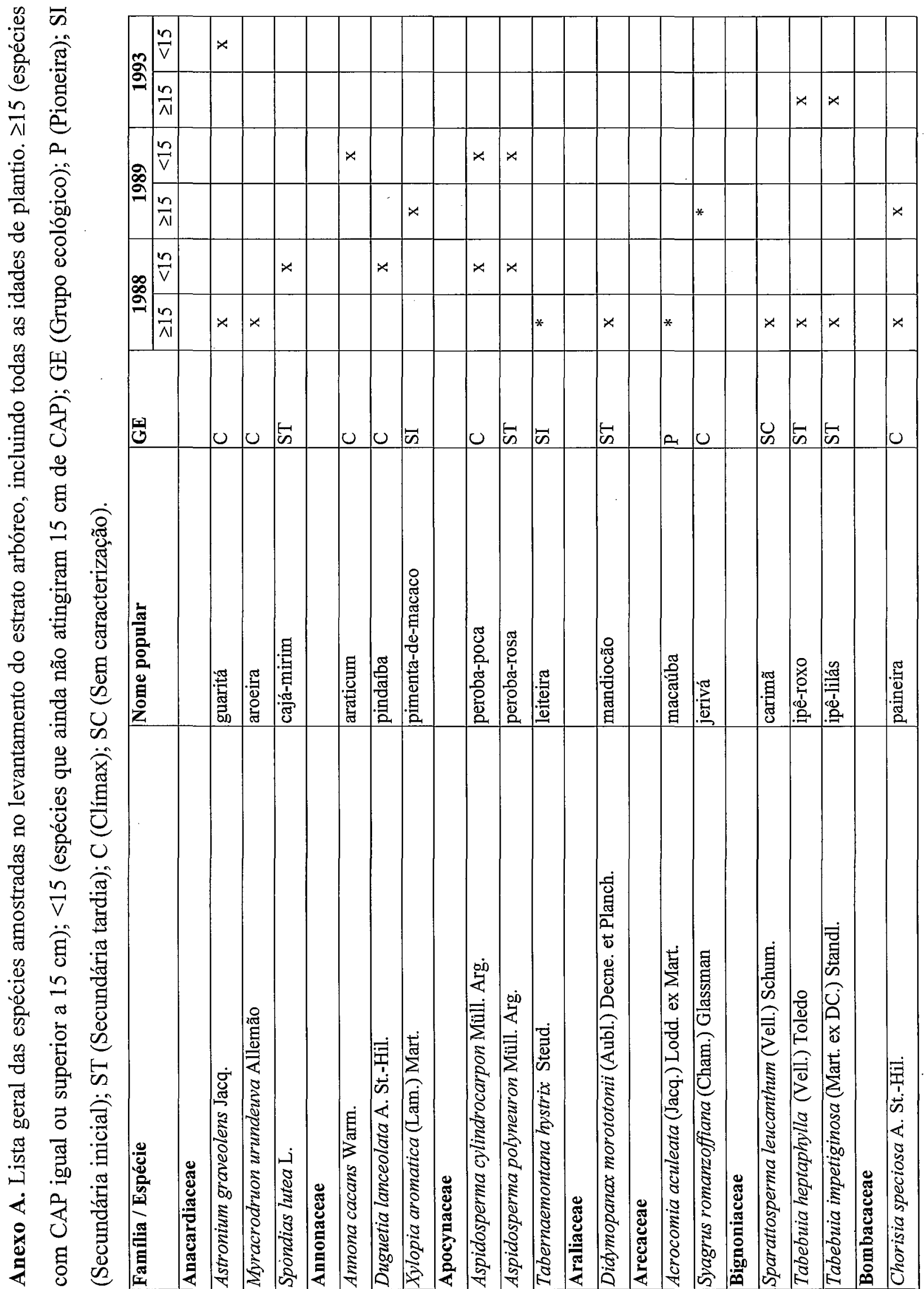




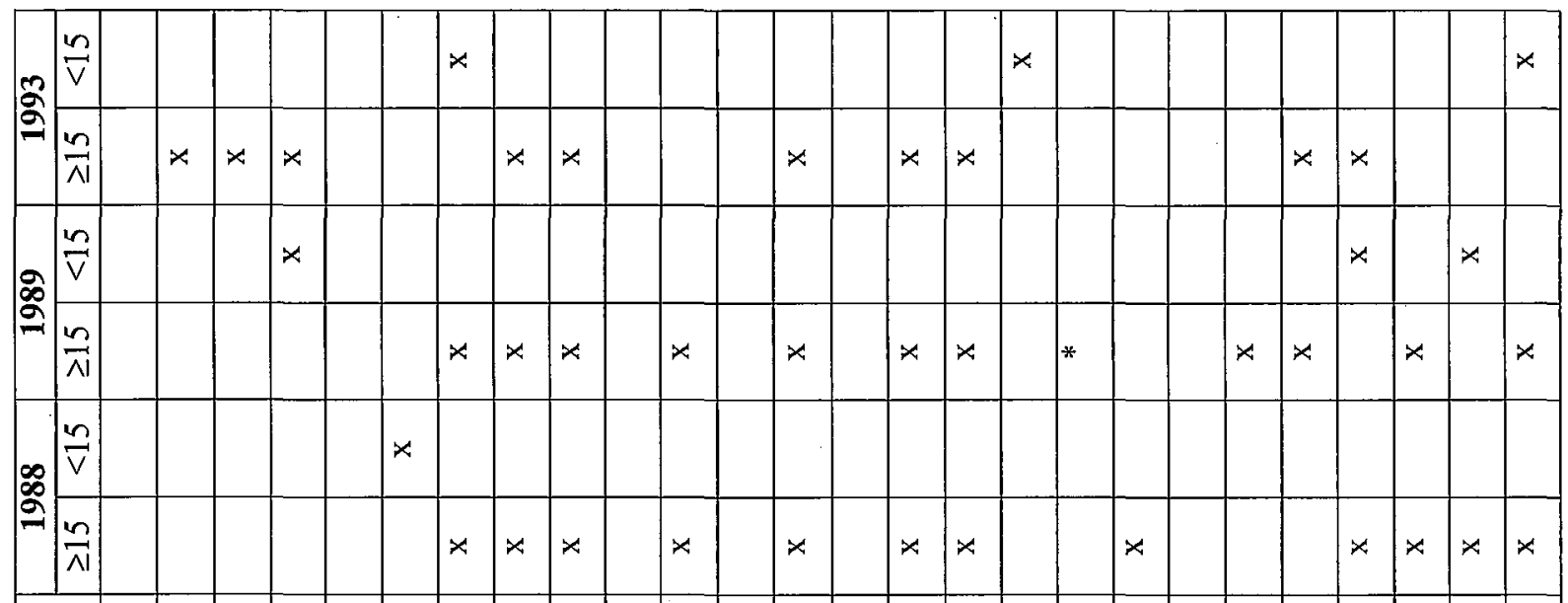

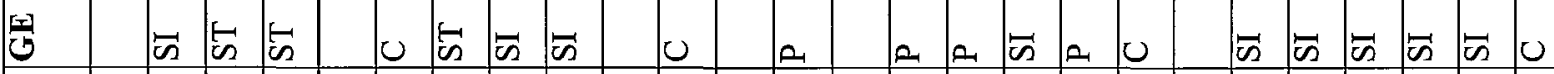

\begin{tabular}{|c|c|c|c|c|c|c|c|c|c|c|c|c|c|c|c|c|c|c|c|c|c|}
\hline & 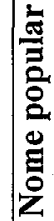 & 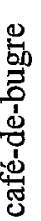 & 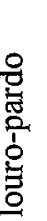 & 茎 & 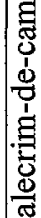 & $\begin{array}{l}\frac{\pi}{0} \\
\frac{0}{0} \\
.\end{array}$ & 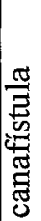 & 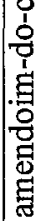 & 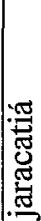 & 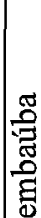 & 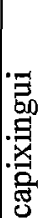 & 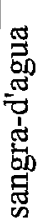 & 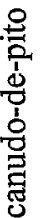 & 总 & & & & & $\mid \begin{array}{l}0 \\
0 \\
0 \\
0 \\
0 \\
0 \\
0 \\
\vdots \\
0 \\
0 \\
0 \\
0\end{array}$ & 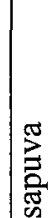 & 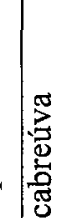 \\
\hline
\end{tabular}




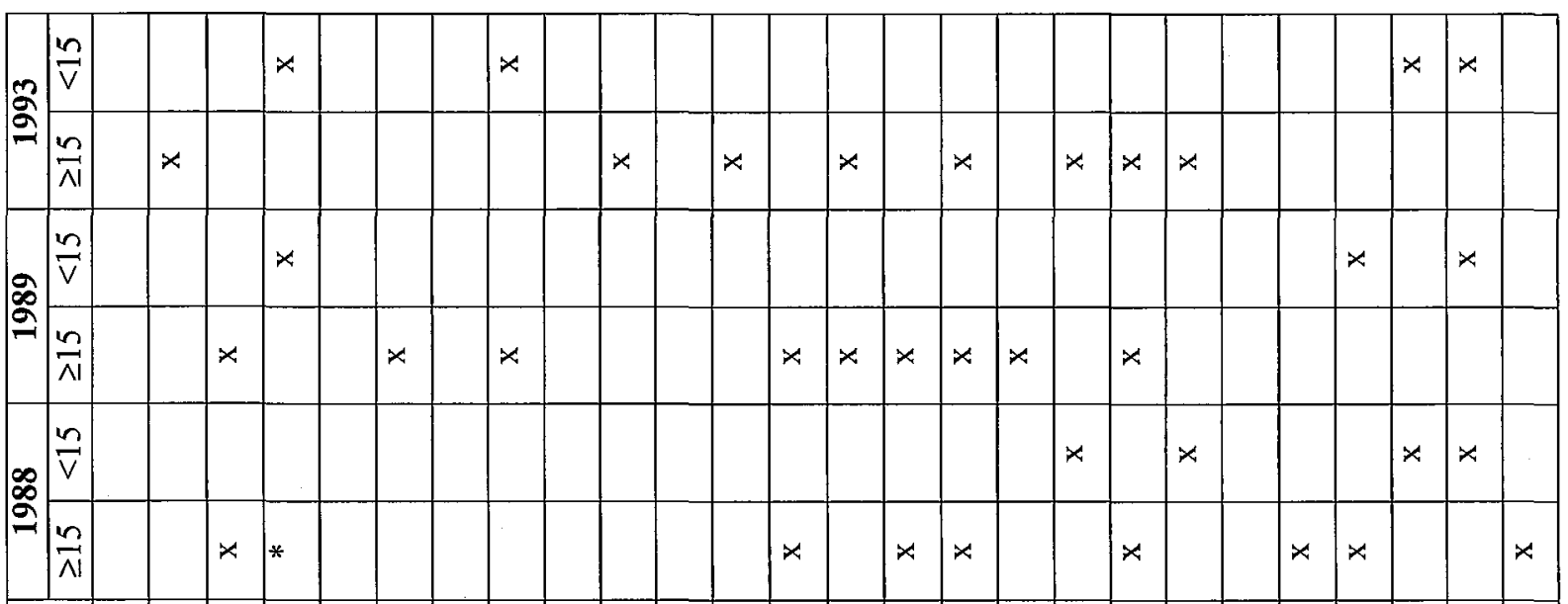

焉

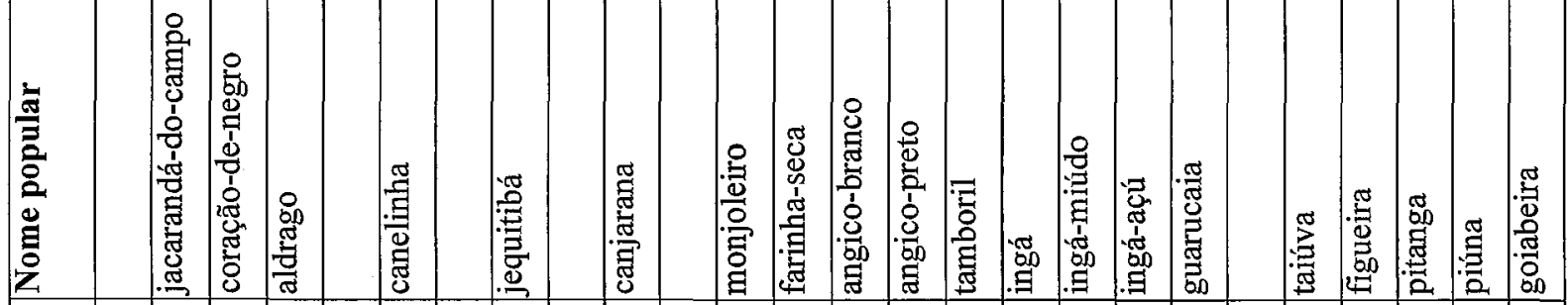

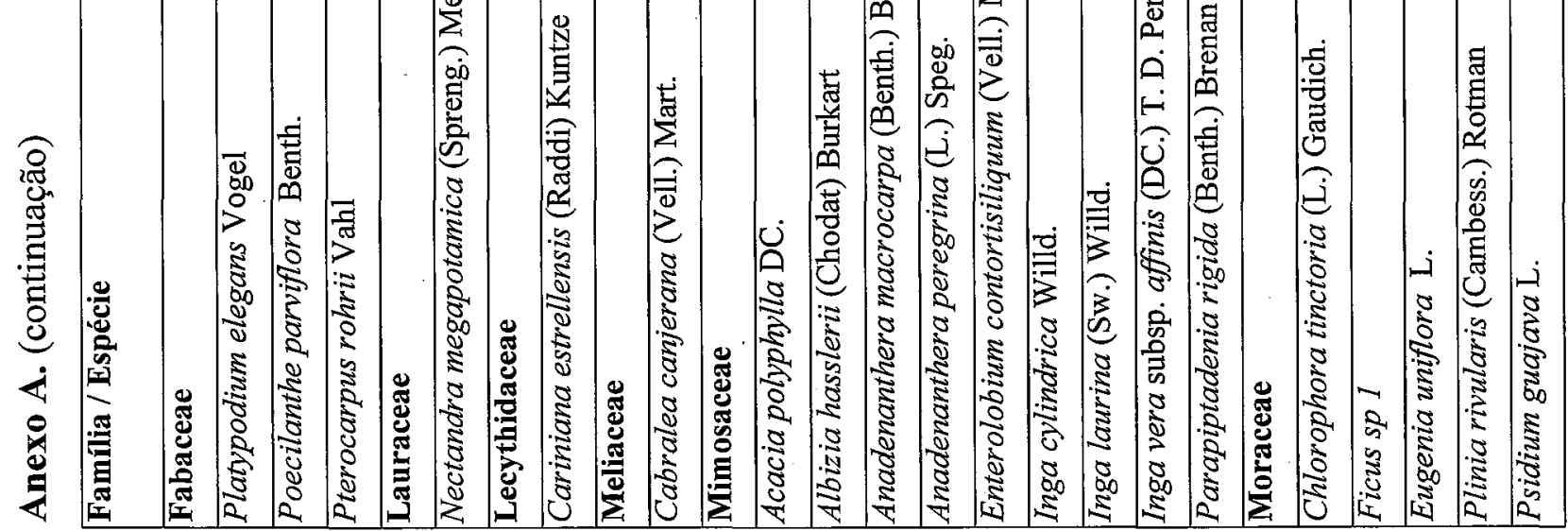




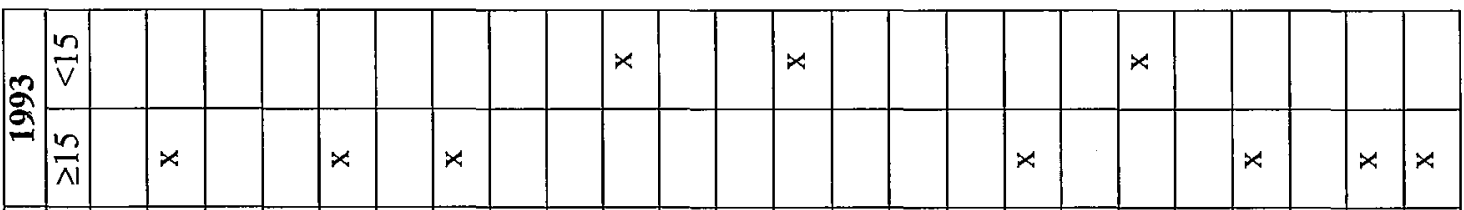

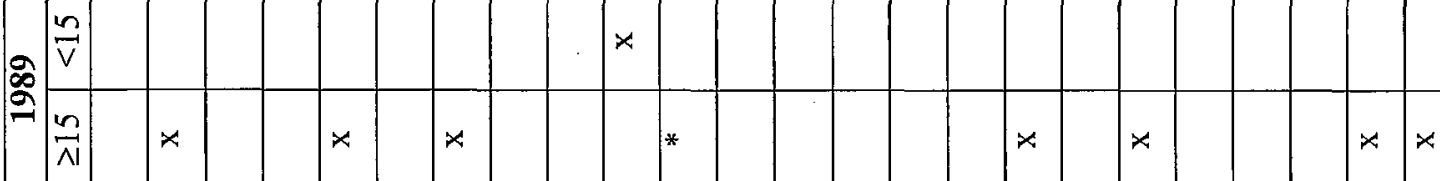

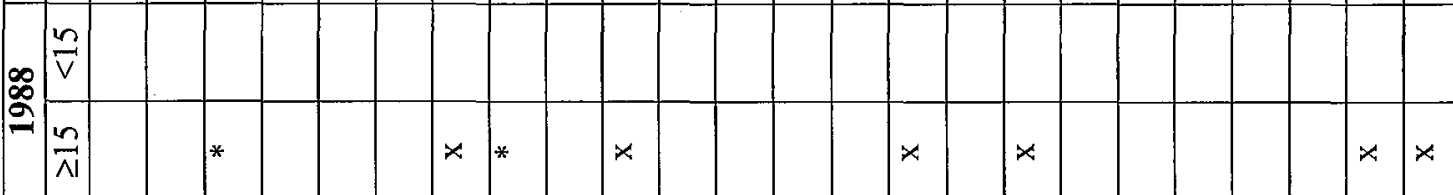

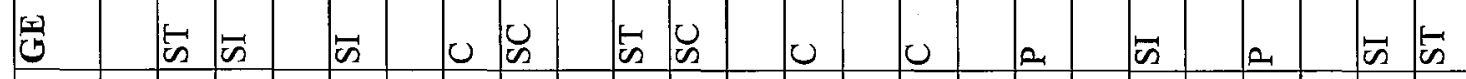

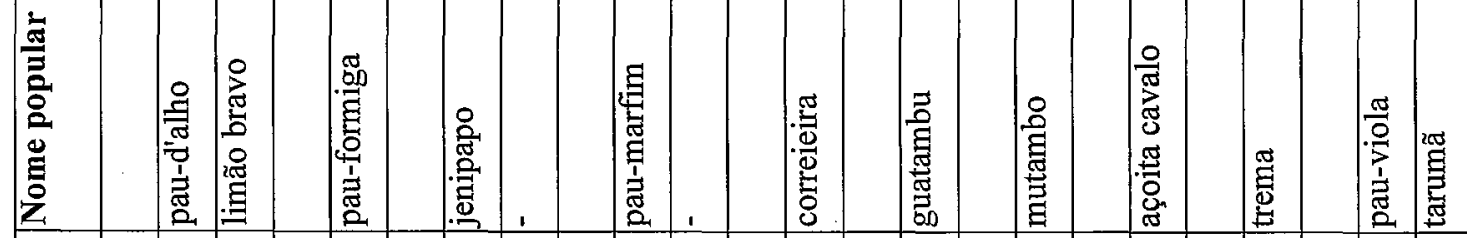

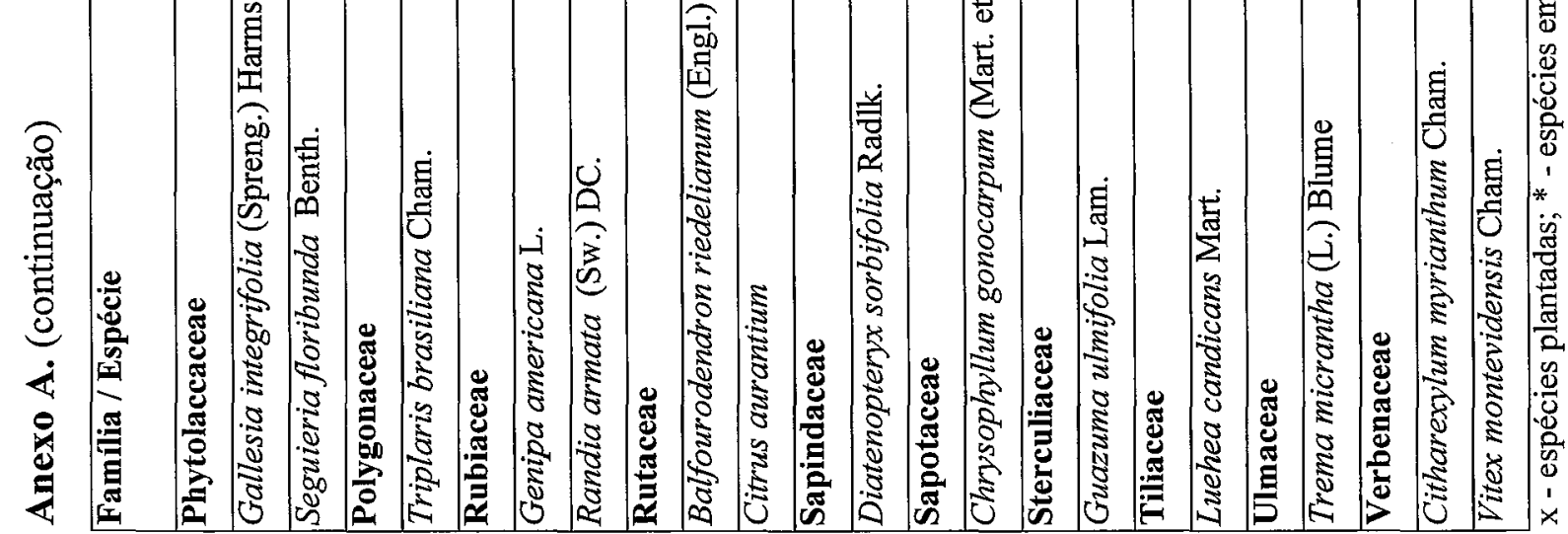




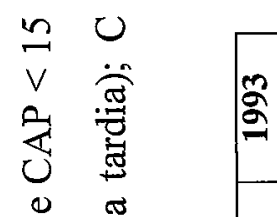

焉

恶

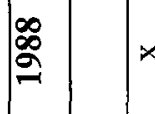

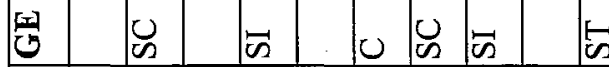

a. 0

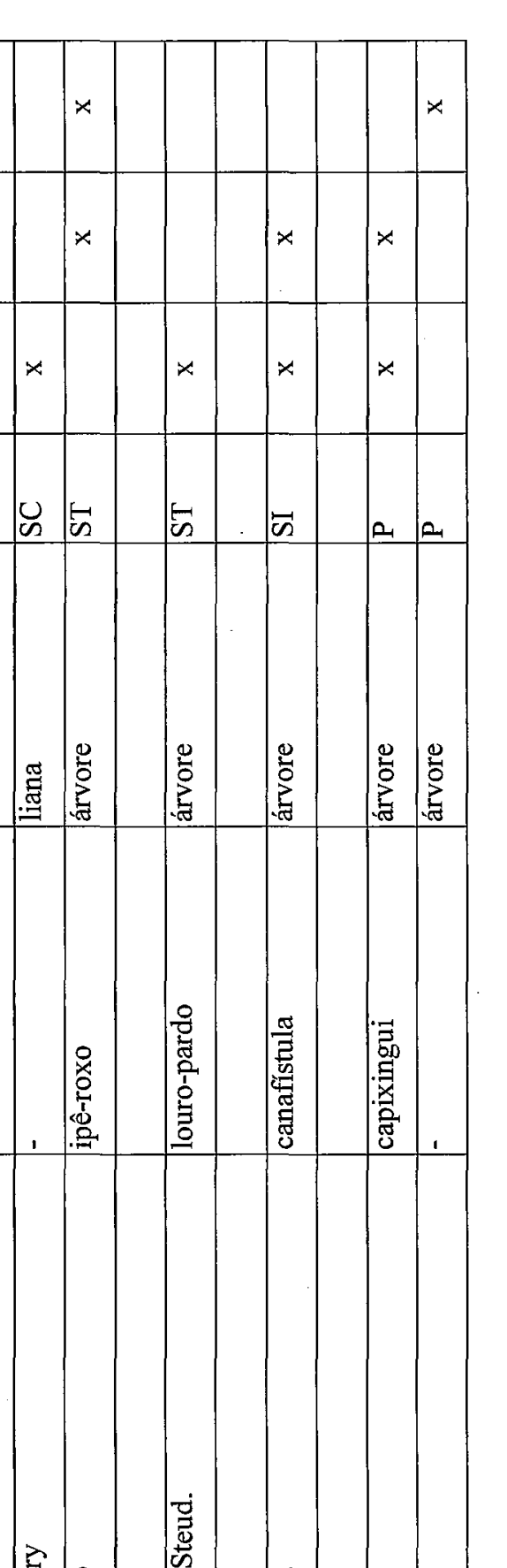

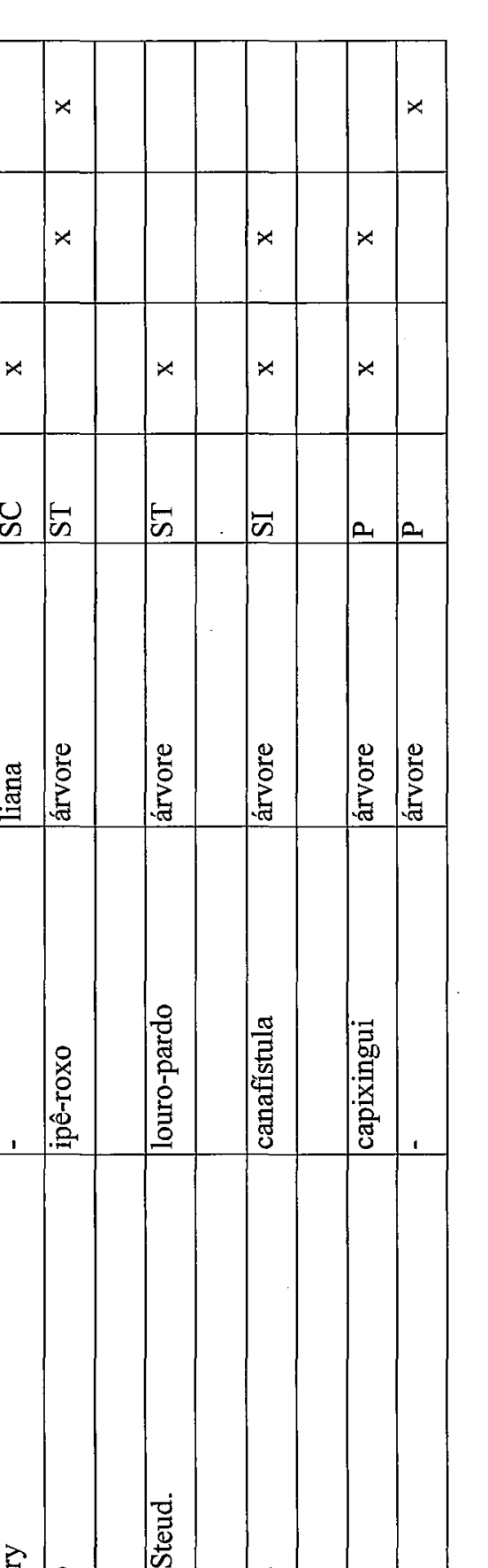

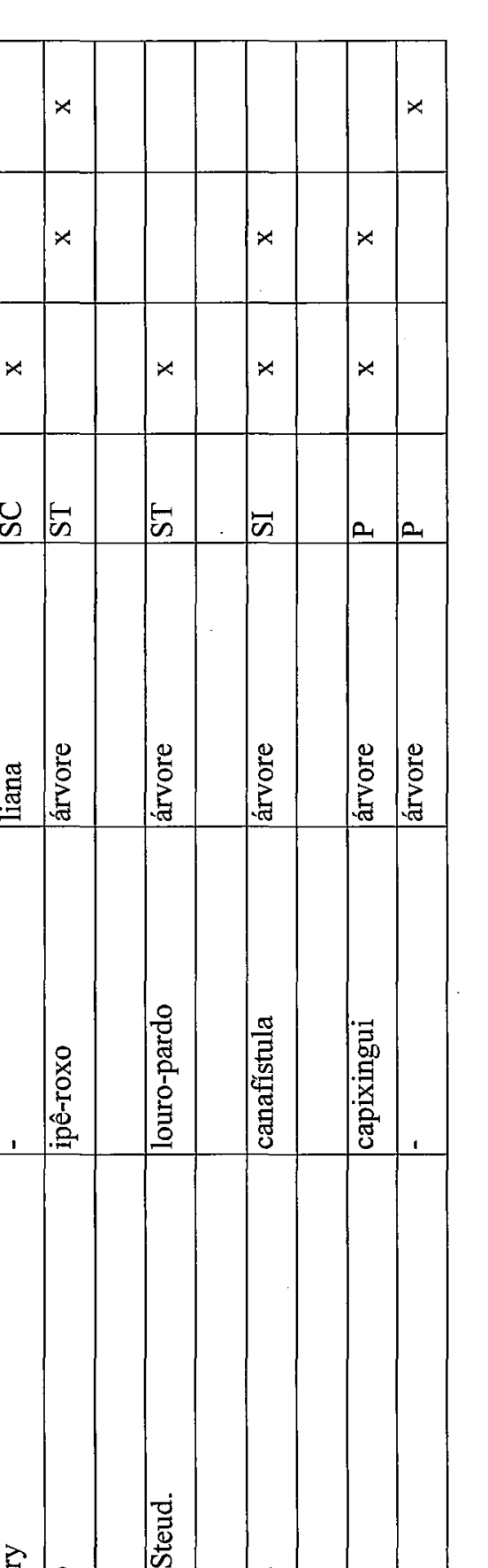

苗

$\underbrace{\infty}_{0}$

$\frac{5}{2}$

ชำ

自

㫄

胥

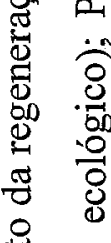

욜 울

空 哲

兄通

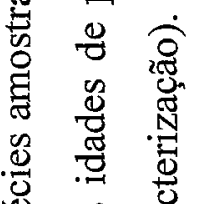

辛

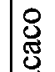

.

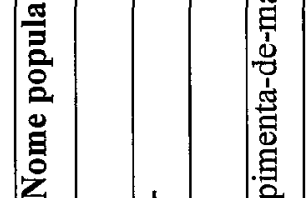

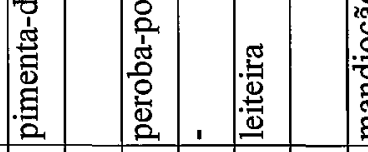

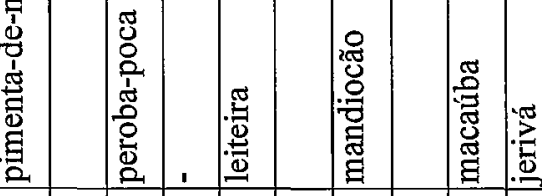

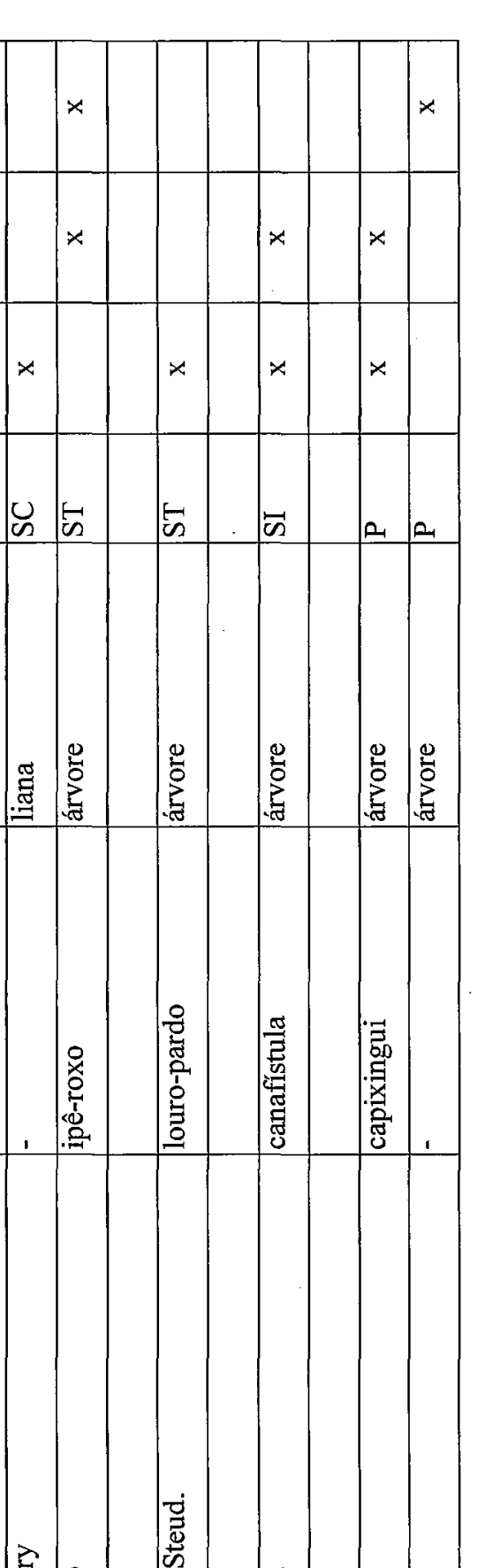

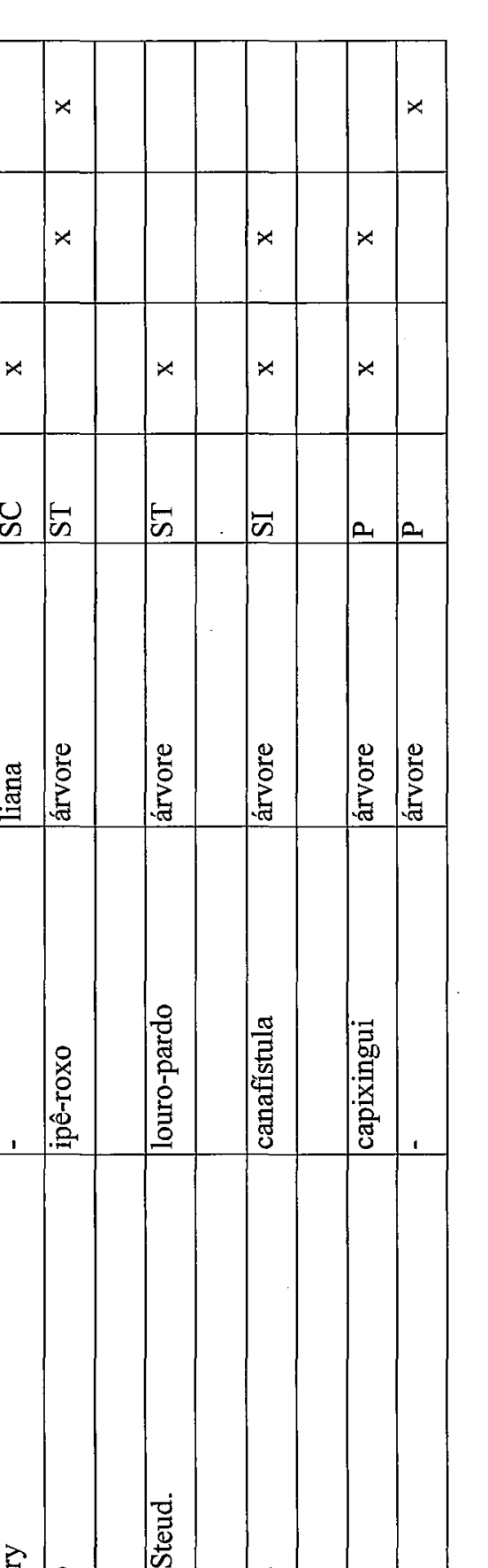

总

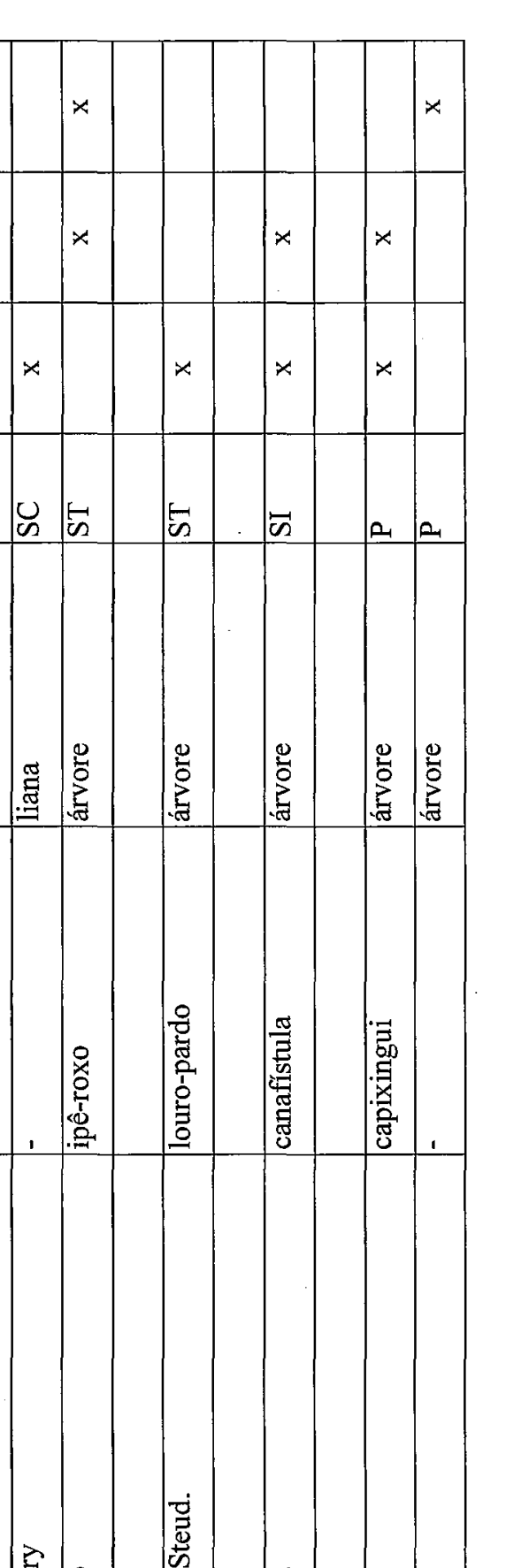

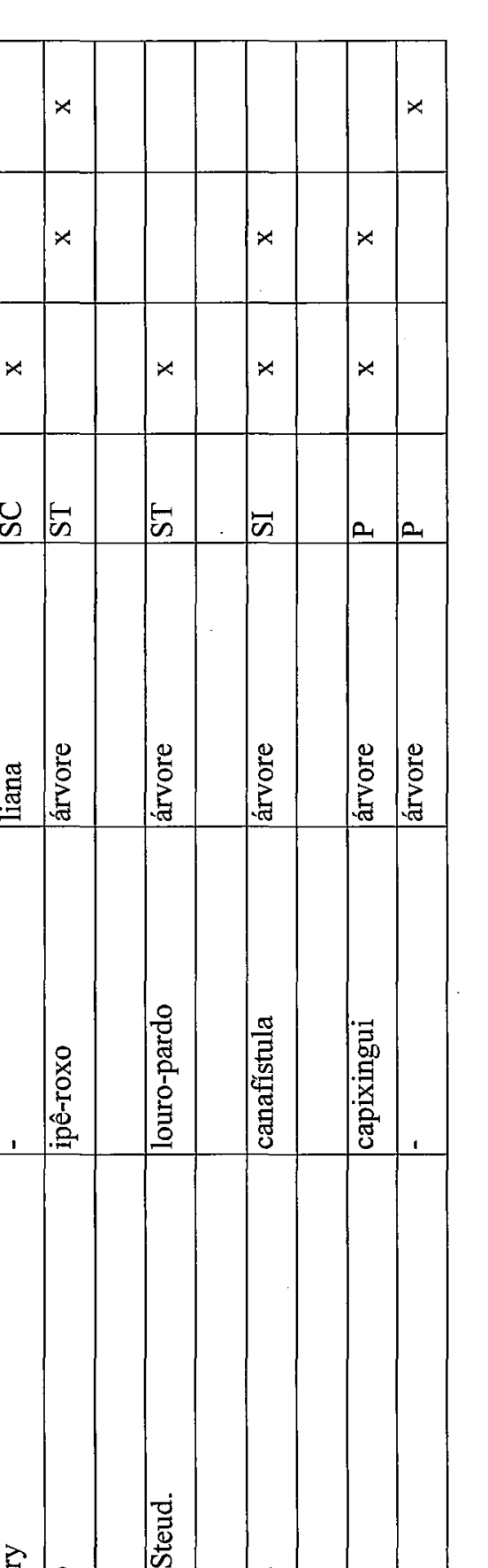

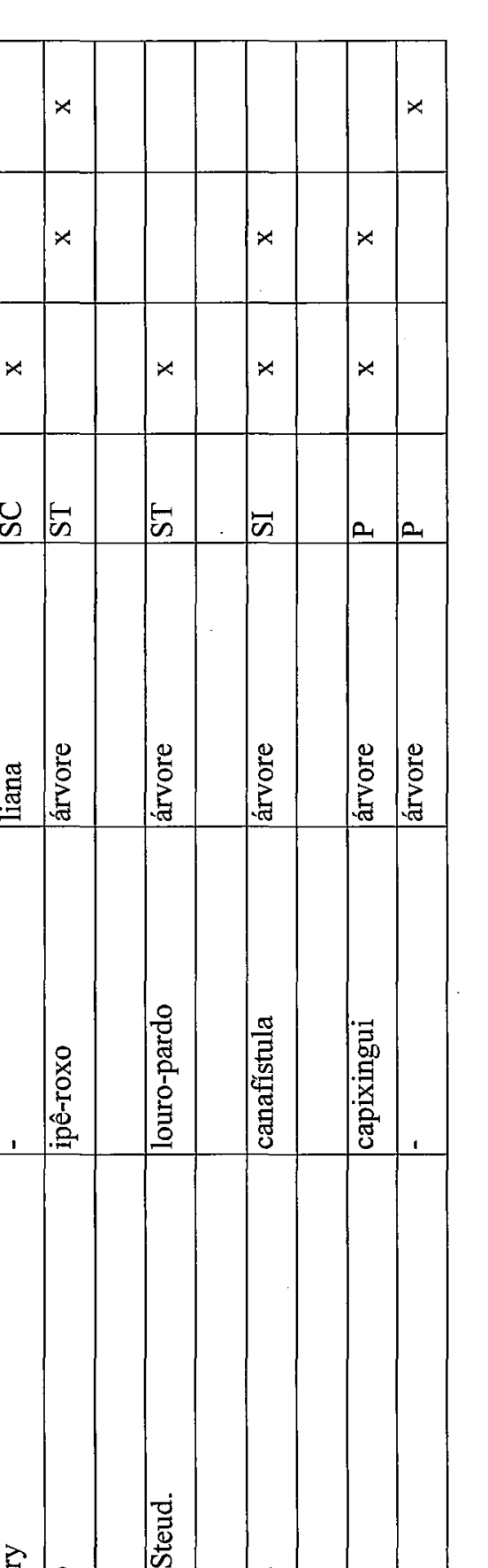

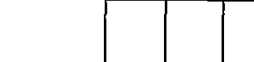

|

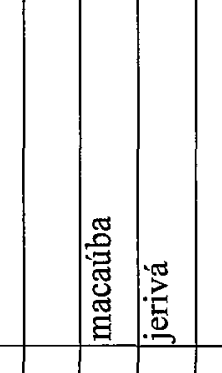

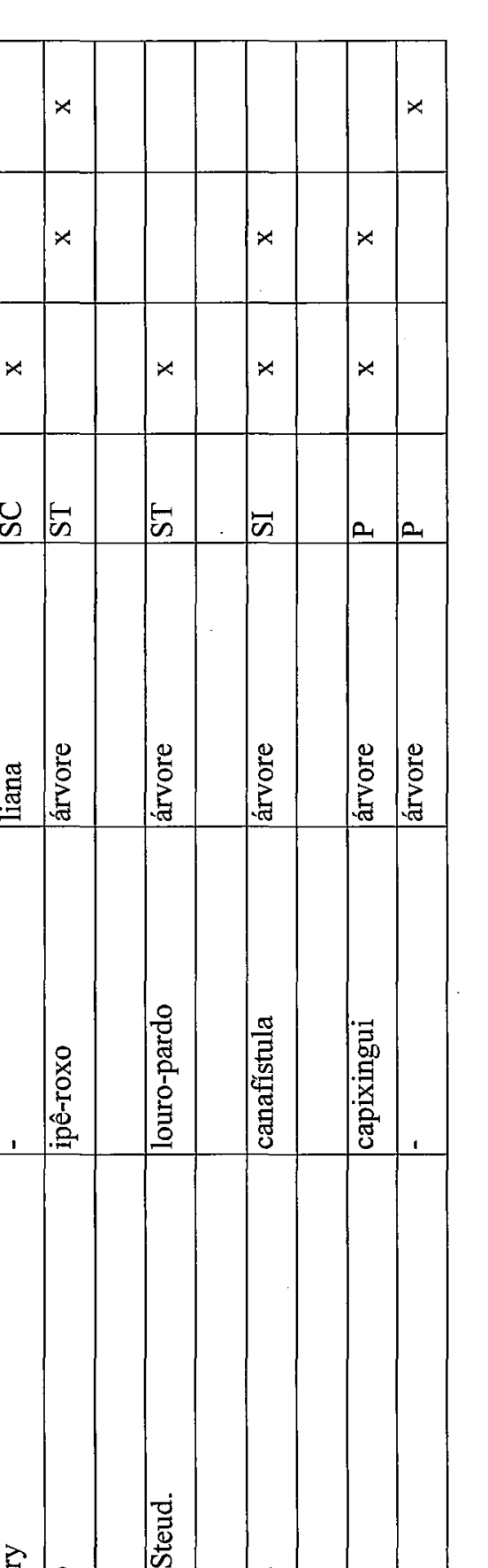

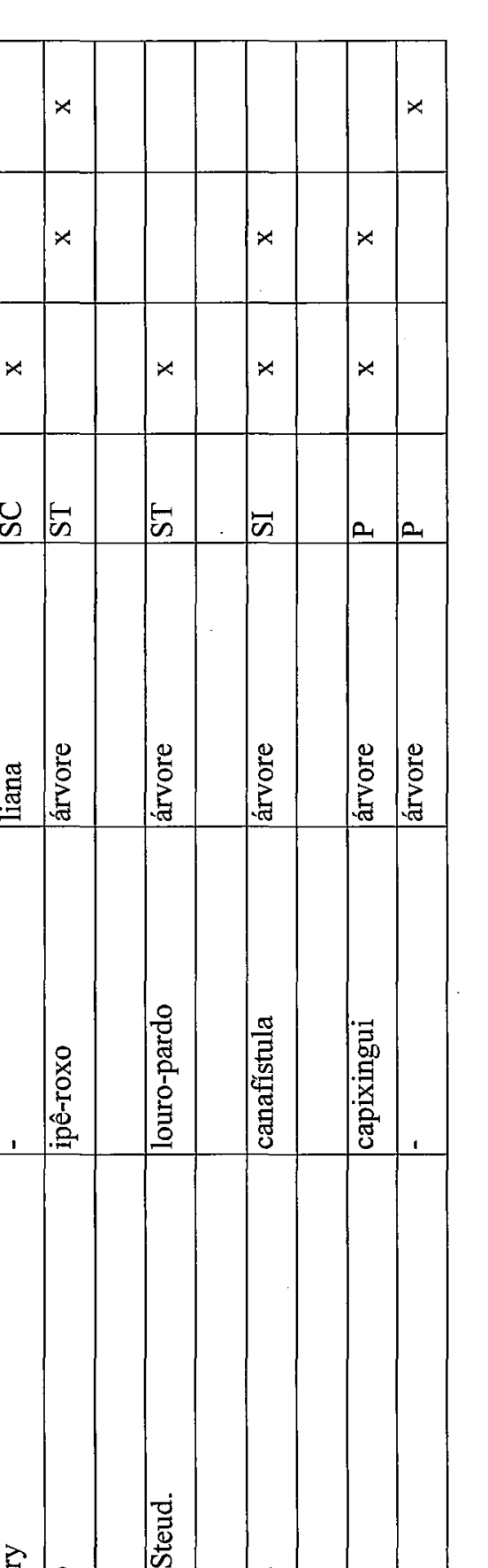

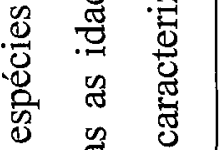

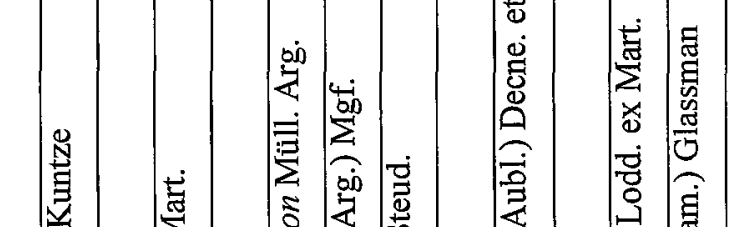

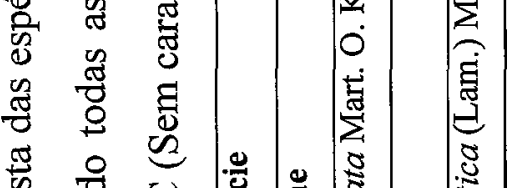

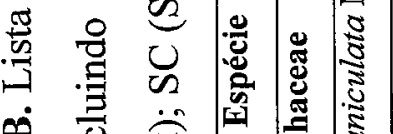

舟

(3)

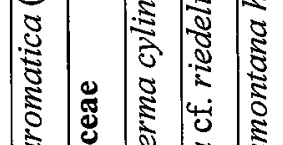

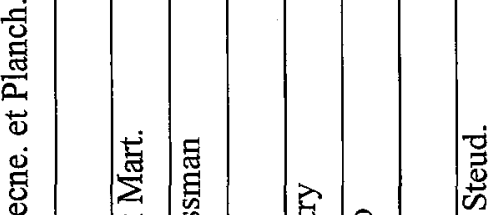

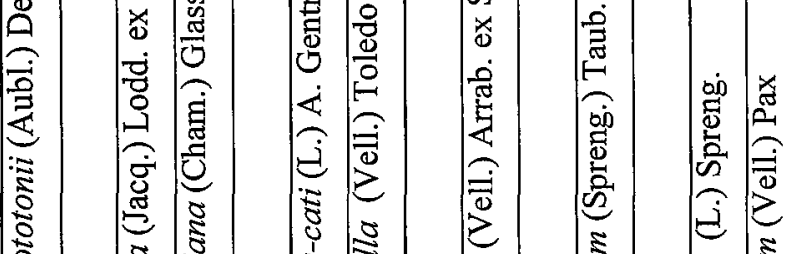

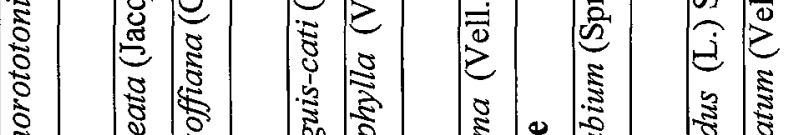

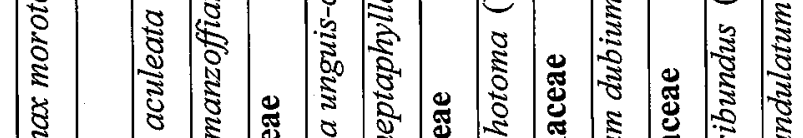

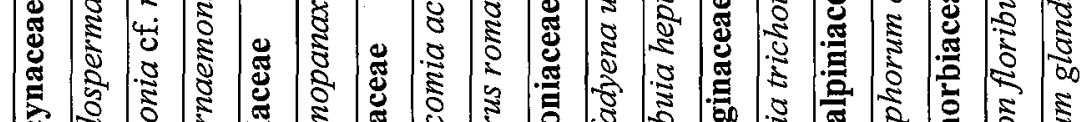

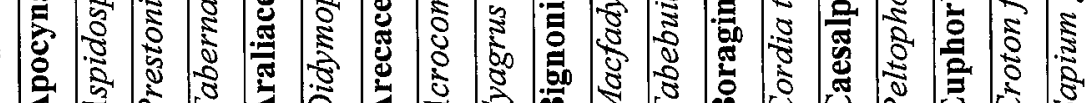




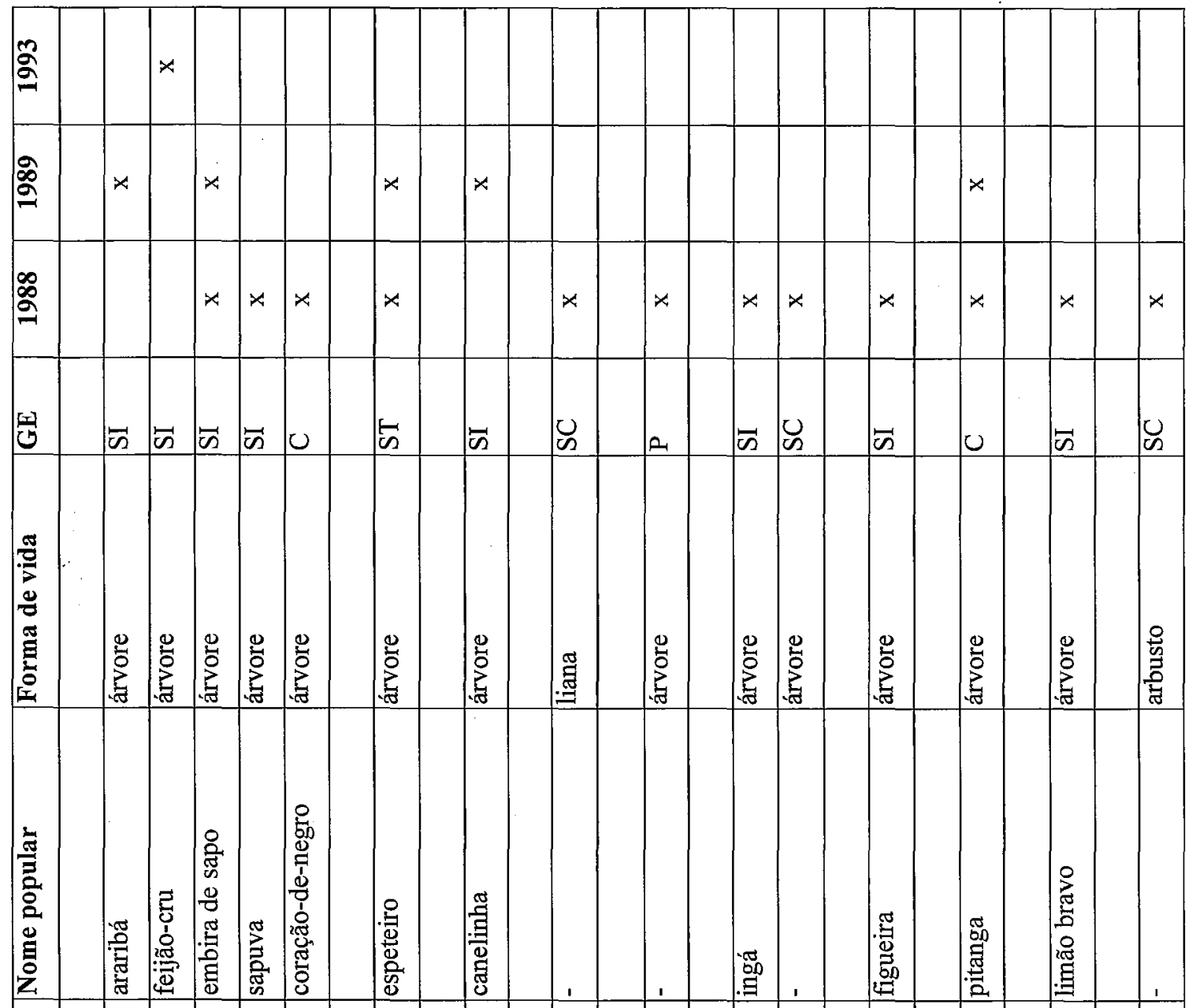

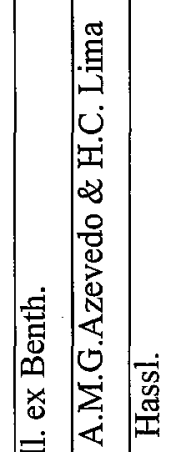

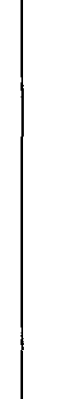

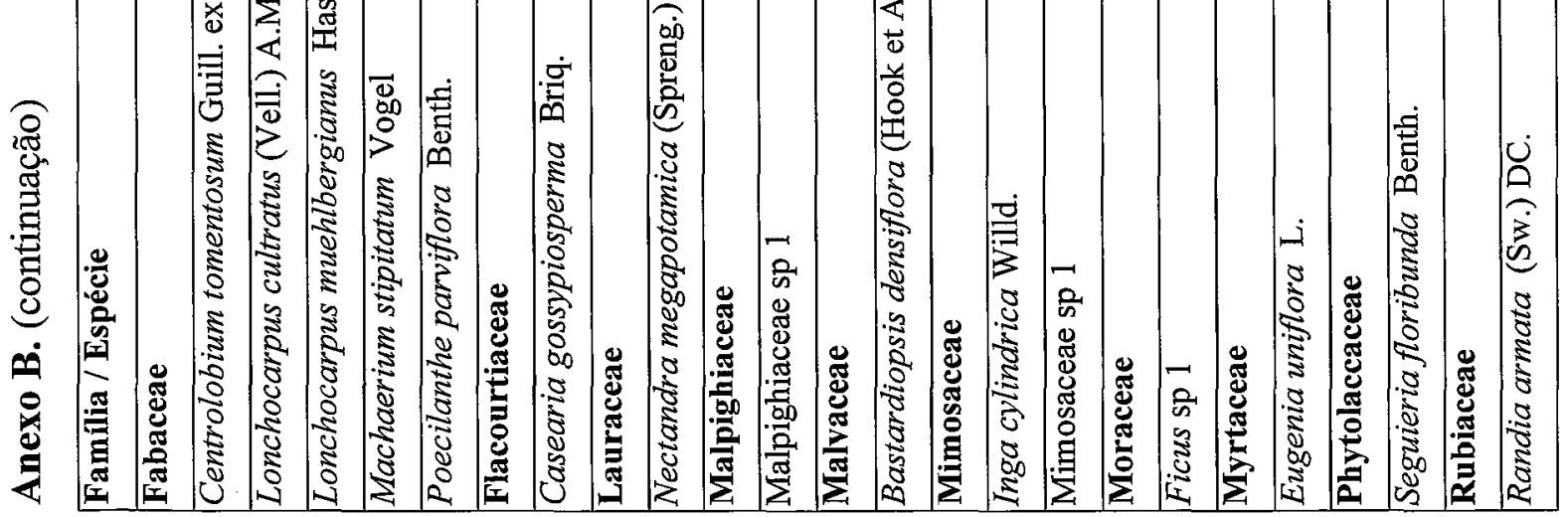

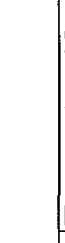$$
\text { . }
$$ 


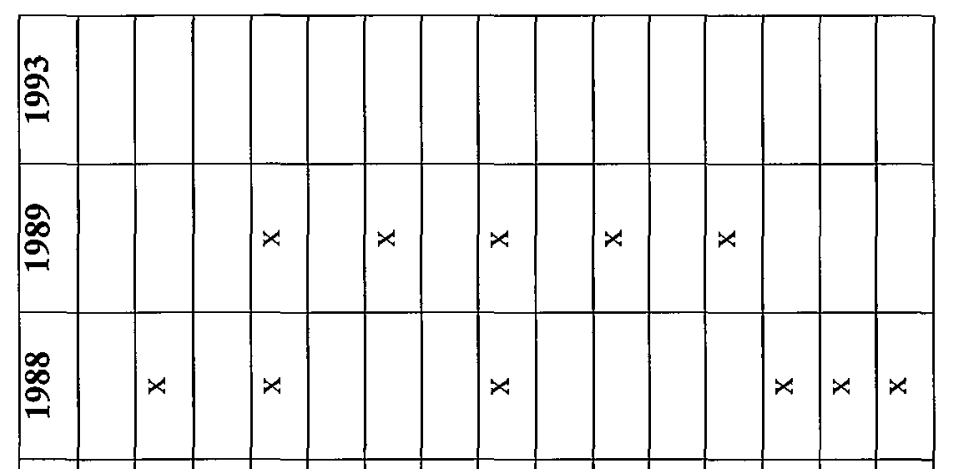

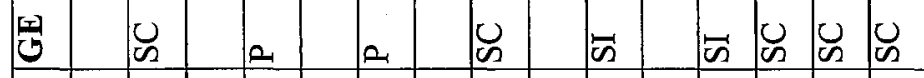

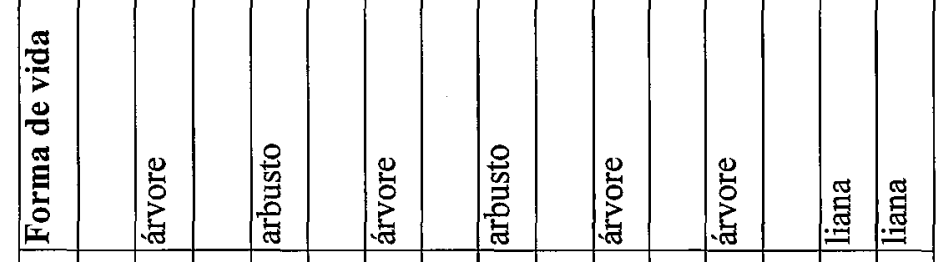

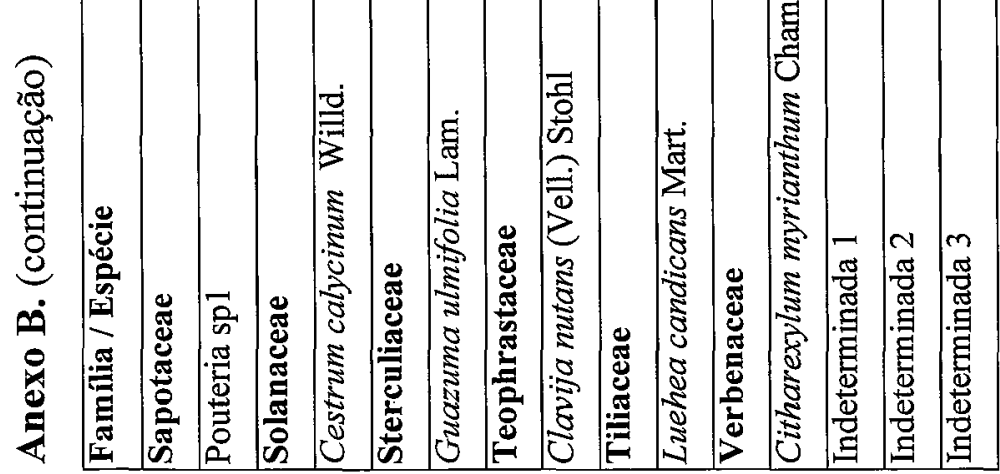

